Environmental Assessment for Enhanced Operations of the Advanced Photon Source at Argonne National Laboratory-East, Argonne, Illinois

U.S. Department of Energy

June 2003

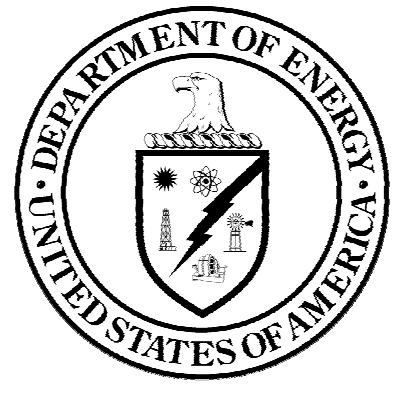





\section{U.S. Department of Energy \\ Finding of No Significant Impact \\ Enhanced Operations of the Advanced Photon Source \\ At Argonne National Laboratory-East \\ Argonne, Illinois}

AGENCY: U.S. Department of Energy

ACTION: Finding of No Significant Impact

\section{SUMMARY:}

The U.S. Department of Energy (DOE) has prepared an Environmental Assessment (EA) DOE/EA-1455, evaluating continued and enhanced operations of the Advanced Photon Source (APS) at Argonne National Laboratory-East, Argonne, Illinois. Based on the analysis in the EA, DOE has determined that the proposed action does not constitute a major Federal action significantly affecting the quality of the human environment within the meaning of the National Environmental Policy Act of 1969 (NEPA).

\section{DESCRIPTION OF THE PROPOSED ACTION:}

The proposed action includes continued and enhanced operations of the APS. The APS is a national synchrotron-radiation light source research facility. Members of the international synchrotron-radiation research community use high-brilliance $\mathrm{x}$-ray beams from the APS to conduct basic and applied research in the fields of biology, chemistry, physics, geology, materials science, and others. Continued operations at the APS would include continued research at the APS and ongoing maintenance of the facility. Enhanced operations would include construction and operation of an additional experimental unit, a Center for Nanoscale Materials (CNM) and initiation of Biosafety Level-3 (BSL-3) work in an existing area at the APS constructed for such work. The CNM would include a parking lot and storm water management features that would minimize any impacts on a nearby wetland due to storm water runoff from the CNM and the parking lot.

\section{ALTERNATIVES:}

DOE considered alternative locations and designs for the parking lot associated with the proposed CNM as subalternatives to the proposed action.

DOE also evaluated a no action alternative. Under the no action alternative, current APS operations would continue. However, initiation of BSL-3 research would not occur and the proposed CNM research facility would not be constructed. 


\section{ENVIRONMENTAL IMPACTS:}

Areas of potential environmental impact evaluated in the EA included those associated with continued operation of the APS, the proposed construction and operation of the CNM, and initiation of BSL-3 work. Potential effects to the environment are primarily related to ecological effects during construction and operation of the proposed CNM and human health effects during BSL-3 activities.

The potential ecological effects of construction and operation of the CNM would be impacts of storm water runoff into a restored wetland to the north of the CNM. Potential wetland impacts during construction include erosion of disturbed soil into the wetland. Potential wetland impacts during operation include surges of storm water from impervious areas and runoff of dirt, petroleum products, and road salt from the CNM parking lot. DOE would minimize storm water impacts during construction of the CNM by ensuring adequate erosion control before and during construction. These impacts would be minimized during operation of the CNM by collecting and pumping to the south, away from the restored wetland, most of the runoff from the CNM parking lot and by providing adequate detention and treatment for roof runoff and overflow runoff from the parking lot. Adverse ecological impacts are not expected to result from implementing the Proposed Action.

The potential human health effects of the proposed BSL-3 activities would be the same as those demonstrated for similar laboratories that are required to implement the guidelines established mutually by the Centers for Disease Control and Prevention (CDC) and the National Institutes of Health (NIH). The CDC and NIH define four levels of BSL work, in increasing levels of precaution, BSL-1, BSL-2, BSL-3, and BSL-4. BSL levels are specific combinations of work practices, safety equipment and facilities that are designed to minimize the exposure of workers and the environment to infectious agents. BSL-3 applies to agents that may be transmitted by the respiratory route and which can cause serious infections. BSL-3 work at the APS would be limited to one BSL-3 hazard at a time. The amount of BSL-3 samples at the APS at any time would be limited to 10 milliliters. Samples would be either pre-frozen or mounted in quartz capillaries. Human health information gathered from ANL's past experience with BSL-1 and BSL-2 laboratories, from the U.S. Bureau of Labor Statistics and from anecdotal information in published reports, indicates that while laboratory-acquired or laboratory-associated infections sometimes occur, they should be considered abnormal events due to their infrequency.

Radiological impacts from APS operations would not change and would remain very much below applicable standards and regulations.

DETERMINATION: Based on the analysis in the EA, DOE has determined that the continued operation of the APS, the proposed construction and operation of the CNM, and initiation of BSL-3 work at the APS in Argonne, Illinois, does not constitute a major Federal action significantly affecting the quality of the human environment within the 
meaning of NEPA. Therefore, an environmental impact statement on the proposed action is not required.

PUBLIC AVAILABILITY: Copies of the EA (DOE/EA-1455) are available by contacting:

Donna Green

U.S. Department of Energy

Argonne Area Office

9800 S. Cass Avenue

Argonne, Illinois 60439

(630) 252-2264

A copy may be viewed online at: http://www.ch.doe.gov

Copies of the EA are also available for review at the following locations:

Lemont Public Library

50 East Wend Street

Lemont, IL 60439

Indian Prairie Public Library

Reference Section

401 Plainfield Road

Darien, IL 60561

For further information regarding the DOE NEPA process, contact:

Peter R. Siebach

NEPA Compliance Officer

U.S. Department of Energy

Chicago Operations Office

9800 S. Cass Avenue

Argonne, IL 60439

Telephone: (630) 252-2007

Issued in Argonne, Illinois this 27 day of $\operatorname{Tan}_{\text {, }}, 2003$.

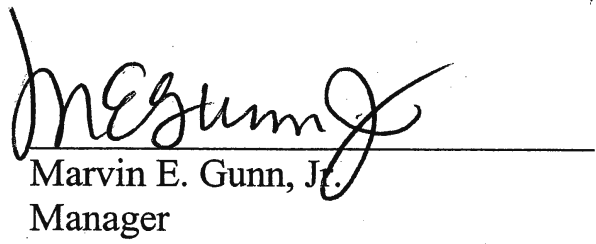





\title{
ENVIRONMENTAL ASSESSMENT FOR ENHANCED OPERATIONS OF THE ADVANCED PHOTON SOURCE AT ARGONNE NATIONAL LABORATORY-EAST, ARGONNE, ILLINOIS
}

\section{U.S. DEPARTMENT OF ENERGY}

\author{
June 2003
}





\section{CONTENTS}

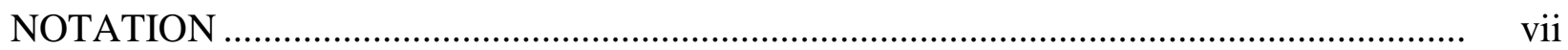

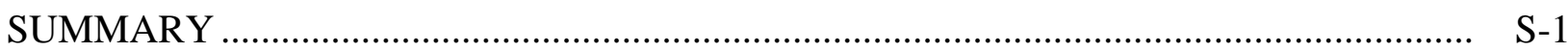

1 INTRODUCTION

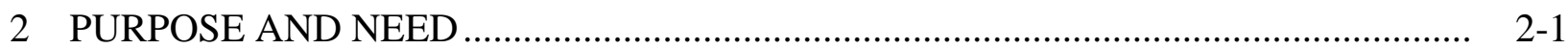

3 THE PROPOSED ACTION AND THE NO-ACTION ALTERNATIVE .......................... 3-1

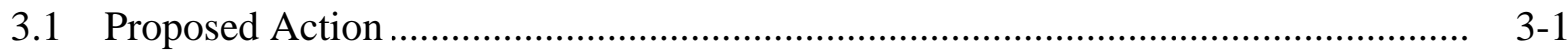

3.1.1 Continued Operations..................................................................... 3-1

3.1.2 Enhanced Operations: BSL-3 Research Proposed for the APS ................... 3-5

3.1.3 Enhanced Operations: Construction and Operation of a

Nanoscale Science Facility ……………................................................. 3-9

3.1.4 Schedule and Manpower ........................................................................ 3-14

3.2 No-Action Alternative................................................................................ 3-15

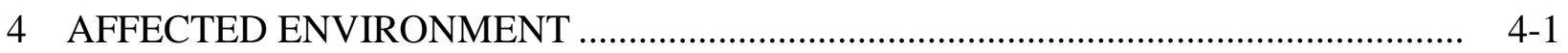

$4.1 \quad$ Site Description ........................................................................................ 4-1

4.2 Geology and Soils ......................................................................................... 4- 4

4.3 Water Resources........................................................................................ 4-2

4.3.1 Surface Water ............................................................................... 4-2

4.3.2 Groundwater................................................................................... 4-4

4.4 Air Quality and Noise ……………………….......................................... 4-5

4.4.1 Meteorology .............................................................................. 4-5

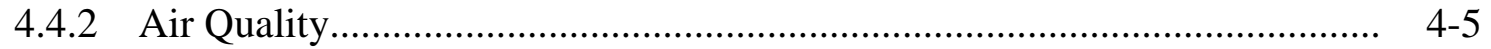

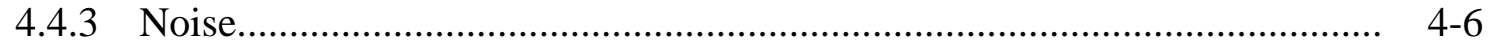

4.5 Land Use, Recreation, and Aesthetics............................................................... 4-6

4.6 Ecological Resources ................................................................................... 4

4.6.1. Terrestrial Biota................................................................................. 4-8

4.6.2 Wetlands and Aquatic Biota.................................................................... 4-9

4.6.3 Threatened and Endangered Species............................................................ 4-12

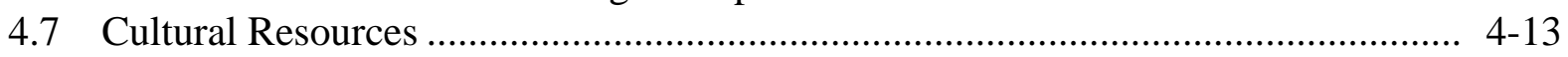

4.7.1 Archaeological Resources ....................................................................... 4-13

4.7.2 Traditional Cultural Properties.................................................................... 4-14

4.7.3 Historic Structures .......................................................................... 4-14

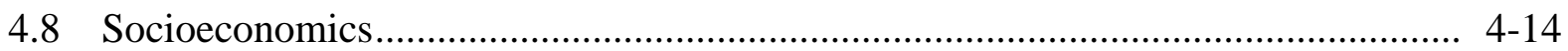

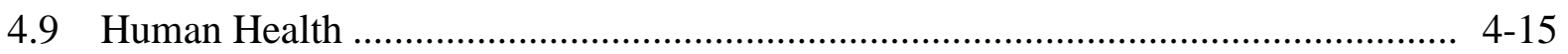

4.9.1 Radiological Environment..................................................................... 4-15

4.9.2 Nonradiological Environment ............................................................. 4-19

4.10 Waste Management .................................................................................... 4-20 


\section{CONTENTS (Cont.)}

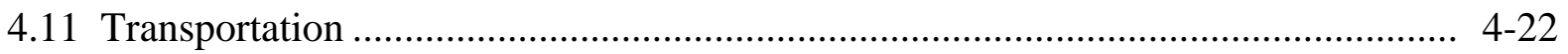

4.12 Utilities and Services................................................................................ 4-23

4.13 Environmental Justice …………................................................................... 4-23

5 ENVIRONMENTAL CONSEQUENCES OF THE PROPOSED ACTION

AND THE NO-ACTION ALTERNATIVE ……………........................................... $5-1$

5.1 Effects of the Proposed Action.......................................................................... 5-1

5.1.1 Soils....................................................................................... 5

5.1.2 Water Resources.......................................................................... 5-2

5.1.3 Air Quality and Noise ………............................................................ 5-7

5.1.4 Land Use, Recreation, and Aesthetics..................................................... 5-8

5.1.5 Ecological Resources ............................................................................. 5-9

5.1.6 Cultural Resources .......................................................................... 5-14

5.1.7 Socioeconomics................................................................................... 5-14

5.1.8 Human Health ............................................................................... 5-15

5.1.9 Waste Management …………………………........................................... 5-23

5.1.10 Transportation ..................................................................................... 5-24

5.1.11 Utilities and Services............................................................................ 5-25

5.1.12 Environmental Justice ……………………...................................... 5-25

5.2 Effects of No Action …………………………............................................ 5-25

5.3 Cumulative Effects of the Proposed Action........................................................... 5-26

6 CONSULTATION LETTERS ………………................................................... 6-1

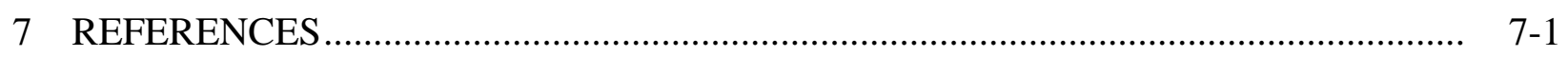

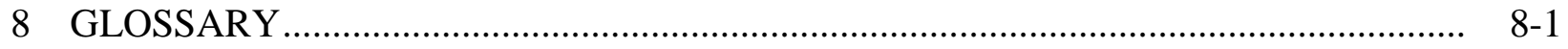

APPENDIX A: Activities and Impacting Factors Associated with the

Proposed Biological Safety Level-3 Facility .............................................. A-1

APPENDIX B: Experimental Activities and Impacting Factors Associated

with the Proposed Center for Nanoscale Materials Facility .......................... B-1

APPENDIX C: Environmental Permits in Effect as of December 31, 2001, at Argonne National Laboratory-East.

APPENDIX D: Calculations Related to Contaminants in Parking Lot Stormwater Runoff .....

APPENDIX E: Evaluation of Alternative Parking Lot Siting Options for the Center for Nanoscale Materials 


\section{FIGURES}

1.1 Location of Argonne National Laboratory-East........................................................ 1-1

1.2 Advanced Photon Source, Argonne National Laboratory-East ...................................... 1-2

3.1 Location of the Advanced Photon Source at Argonne National Laboratory-East .......... 3-2

3.2 APS Accelerator Subsystems and Related Structures.................................................. 3-3

3.3 Diagram of the BioCARS Facility ……………................................................... 3-7

3.4 Diagram of a Typical Package Used to Ship Biological Materials to and from the BioCARS Facility ................................................................................ 3-9

3.5 Planned Construction at the Advanced Photon Source ................................................ 3-10

4.1 Surface Drainage Patterns for the APS Site …………............................................... 4-3

4.2 Wetland Area and Wooded Area at the APS Site .......................................................... 4-10

4.3 Location of the Maximum Credible Incident ............................................................ 4-18

4.4 Minority Composition of Populations within 5 and 50 Miles of ANL-E, Based on 2000 U.S. Census Data............................................................................. 4-25

4.5 Income Composition of Populations within 5 and 50 Miles of ANL-E, Based on 1990 U.S. Census Data................................................................................ 4-26

5.1 Direction of Stormwater Flow in the Area of the CNM Facility .................................. 5-3

E.1 Alternative Parking Lot Sites ......................................................................... E-4

E.2 Surface Elevations Associated with Stormwater Drainage Alternatives ........................ E-8

\section{TABLES}

4.1 Emissions from ANL-E and Nearby Counties ......................................................... 4-6

4.2 National and Illinois Ambient Air Quality Standards ................................................... 4- 4-7

4.3 Radiation Dose to Latent Cancer Risk Conversion Factors ............................................ 4-15 


\section{TABLES (Cont.)}

4.4 Maximum Radiation Doses to Various Receptors from the APS Operations

4.5 Hazardous and Radiological Waste Generated Annually by ANL-E and the APS

4.6 Summary of the Distribution of Minority and Low-Income Populations Surrounding ANL-E.

5.1 Water Quality Criteria for Aquatic Biota for Common Parking Lot

Runoff Constituents...

5.2 Road and Parking Surface Runoff Concentrations, Bioretention Swale

Reduction Rates, Resulting Concentrations, and Discharge Concentrations

5.3 Comparison of Radiation Exposures Presented in This EA with Those Reported in the 1990 APS EA.

5.4 Hazardous Waste, Radiological Waste, and Wastewater Generated Annually by ANL-E and the APS under the Proposed Action

A.1 CDC Definitions of Biosafety Levels

B.1 Types of Chemicals Routinely Used to Support Nanoscale Research Activities .

D.1 Surface Areas of Land and Facilities within Wetland 302 Watershed

D-4

D.2 Estimated Concentration of Chloride in Runoff from the CNM Drainage Area and the Combined CNM and SW Drainage.

D.3 Potential Runoff Rate from the CNM Parking Lot .

D.4 Collection Capacity Required to Contain Runoff from the CNM Parking Area with Pumping Rate of $80 \mathrm{gpm}$ D-10

D.5 Collection Capacity Required to Contain Runoff from the CNM Parking Area with Pumping Rate of $200 \mathrm{gpm}$.

E.1 Parking Lot Alternatives E-5

E.2 Environmental Parameters of Alternative Parking Sites for the CNM Facility E-6 


\section{NOTATION}

The following is a list of the acronyms, initialisms, and abbreviations (including units of measure) used in this document. Some acronyms used in tables and figures only are defined in the respective tables and figures.

\section{ACRONYMS, INITIALISMS, AND ABREVIATIONS}

\begin{tabular}{|c|c|}
\hline ACIS & Access Control and Interface System \\
\hline ANL-E & Argonne National Laboratory-East \\
\hline APS & Advanced Photon Source \\
\hline BDRP & Biological Defense Research Program \\
\hline BEA & Bureau of Economic Analysis \\
\hline BioCARS & biological segment of the Consortium for Advanced Radiation Sources \\
\hline $\mathrm{BOD}_{5}$ & 5-day biological oxygen demand \\
\hline BSL & Biosafety Level \\
\hline C-11 & carbon-11 \\
\hline CARS & Consortium for Advanced Radiation Sources \\
\hline CAT & Collaborative Access Team \\
\hline $\mathrm{CDC}$ & Centers for Disease Control and Prevention \\
\hline CFR & Code of Federal Regulations \\
\hline CMS & Chemical Management System \\
\hline CNM & Center for Nanoscale Materials \\
\hline $\mathrm{CO}$ & carbon monoxide \\
\hline COD & chemical oxygen demand \\
\hline DOE & U.S. Department of Energy \\
\hline DOT & U.S. Department of Transportation \\
\hline EA & environmental assessment \\
\hline EPA & U.S. Environmental Protection Agency \\
\hline $\mathrm{ESH}$ & Environment, Safety, and Health (manual) \\
\hline FTE & full-time equivalent \\
\hline HEPA & high-efficiency particulate air \\
\hline IBC & Institutional BioSafety Committee \\
\hline IDEQ & Idaho Department of Environmental Quality \\
\hline IEPA & Illinois Environmental Protection Agency \\
\hline ISM & Integrated Safety Management \\
\hline
\end{tabular}




\begin{tabular}{|c|c|}
\hline LEUTL & Low-Energy Undulator Test Line \\
\hline LINAC & linear acceleration/accelerator \\
\hline LLW & low-level radioactive waste \\
\hline LLWM & low-level mixed [radiological and chemical] waste \\
\hline LOM & laboratory office module \\
\hline LWTP & Laboratory Wastewater Treatment Plant \\
\hline MAD & multiwavelength anomalous diffraction \\
\hline MCI & maximum credible incident \\
\hline $\mathrm{N}-13$ & nitrogen-13 \\
\hline NAWQC & National Ambient Water Quality Criteria \\
\hline NCRP & National Council on Radiation Protection and Measurements \\
\hline NEPA & National Environmental Policy Act \\
\hline NESHAP & National Emission Standards for Hazardous Air Pollutants \\
\hline NHPA & National Historic Preservation Act \\
\hline NIH & National Institutes for Health \\
\hline $\mathrm{NO}_{2}$ & nitrogen dioxide \\
\hline $\mathrm{NO}_{\mathrm{x}}$ & nitrogen oxides \\
\hline NPDES & National Pollutant Discharge Elimination System \\
\hline NRHP & National Register of Historic Places \\
\hline $\mathrm{O}-15$ & oxygen-15 \\
\hline $\mathrm{Pb}$ & lead \\
\hline PEIS & programmatic environmental impact statement \\
\hline PFS & Plant Facilities and Services Division \\
\hline $\mathrm{PM}_{10}$ & $\begin{array}{l}\text { particulate matter with an aerodynamic diameter equal to or less than } \\
10 \text { micrometers }\end{array}$ \\
\hline $\mathrm{PM}_{2.5}$ & $\begin{array}{l}\text { particulate matter with an aerodynamic diameter equal to or less than } \\
2.5 \text { micrometers }\end{array}$ \\
\hline PPE & personal protective clothing \\
\hline RCRA & Resource Conservation and Recovery Act \\
\hline SAR & Safety Analysis Review \\
\hline SARA & Superfund Amendments and Reauthorization Act \\
\hline $\mathrm{SO}_{2}$ & sulfur dioxide \\
\hline SOP & standard operating procedure \\
\hline SPPP & Stormwater Pollution Prevention Plan \\
\hline SWMU & solid waste management unit \\
\hline $\begin{array}{l}\text { TRI } \\
\text { TRUW }\end{array}$ & $\begin{array}{l}\text { Toxic Release Inventory } \\
\text { transuranic waste }\end{array}$ \\
\hline
\end{tabular}


VOC volatile organic compound

WMO Waste Management Operations

\section{UNITS OF MEASURE}

$\begin{array}{llll}\text { Btu } & \text { British thermal unit(s) } & \mathrm{m} & \text { meter(s) } \\ & & \mathrm{m}^{2} & \text { square meter(s) } \\ { }^{\circ} \mathrm{C} & \text { degree(s) Celsius } & \mathrm{m}^{3} & \text { cubic meter(s) } \\ \mathrm{Ci} & \text { curie(s) } & \mathrm{MeV} & \text { mega (million) electron volt(s) } \\ \mathrm{cm} & \text { centimeter(s) } & \mathrm{mg} & \text { milligram(s) } \\ & & \mathrm{mi} & \text { mile(s) } \\ { }^{\circ} \mathrm{F} & \text { degree(s) Fahrenheit } & \mathrm{min} & \text { minute(s) } \\ \mathrm{ft} & \text { foot (feet) } & \mu \mathrm{g} & \text { microgram(s) } \\ \mathrm{ft}^{2} & \text { square foot (feet) } & \mu \mathrm{m} & \text { micrometer(s) } \\ \mathrm{ft}^{3} & \text { cubic foot (feet) } & \mathrm{mL} & \text { milliliter(s) } \\ & & \mathrm{mm} & \text { square millimeter(s) } \\ \mathrm{g} & \text { gram(s) } & \mathrm{mm}{ }^{3} & \text { cubic millimeter(s) } \\ \mathrm{gal} & \text { gallon(s) } & \mathrm{mM} & \text { millimole(s) } \\ \mathrm{GeV} & \text { giga (billion) electron volt(s) } & \mathrm{MMBtu} & \text { million British thermal unit(s) } \\ \mathrm{gpm} & \text { gallon(s) per minute } & \mathrm{mrem} & \text { millirem(s) } \\ \mathrm{h} & \text { hour(s) } & \mathrm{MW} & \text { megawatt(s) } \\ \mathrm{ha} & \text { hectare(s) } & & \\ & & \mathrm{nL} & \text { nanoliter(s) } \\ \mathrm{in} . & \text { inch(es) } & & \\ \mathrm{kg} & \text { kilogram(s) } & \mathrm{ppm} & \text { part(s) per million } \\ \mathrm{km} & \text { kilometer(s) } & & \\ \mathrm{L} & \text { liter(s) } & \mathrm{scf} & \text { standard cubic foot (feet) } \\ \mathrm{lb} & \text { pound(s) } & & \\ & & \mathrm{yr} & \text { year(s) }\end{array}$




\section{SUMMARY}

This environmental assessment (EA) has been prepared by the U.S. Department of Energy (DOE) in compliance with the National Environmental Policy Act of 1969 (NEPA) to evaluate the potential environmental impacts associated with continued and enhanced operation of the Advanced Photon Source (APS), including modifications, upgrades, and new facilities, at Argonne National Laboratory-East (ANL-E) in DuPage County, Illinois. This proposed action is needed to meet DOE's mission of sponsoring cutting-edge science and technology. Continued operation would include existing research activities. In 2002, 23 user teams had beamlines in use in 28 sectors of the experiment hall, and approximately 2,000 individual users visited annually (see Section 3.1.1). Enhanced scientific capabilities would include research on Biosafety Level-3 (BSL-3) materials in an existing area originally constructed for such work, and would not require new construction or workforce (see Section 3.1.2). A new experimental unit, the Center for Nanoscale Materials (CNM), would be constructed along the west side of the APS facility and would be used for bench-scale research in nanoscience (see Section 3.1.3).

Under the No Action Alternative, current APS operations would continue. However, initiation of BSL-3 research would not occur, and the proposed CNM research facility would not be constructed.

The environmental consequences of the Proposed Action are minor. Potential effects to the environment are primarily related to ecological effects during construction and operation of the proposed CNM and human health effects during BSL-3 activities.

The potential ecological effects of construction and operation of the CNM would be impacts of stormwater runoff into a restored wetland to the north of the CNM. DOE would minimize stormwater impacts during construction of the CNM by ensuring adequate erosion control before and during construction. Stormwater impacts would be minimized during operation of the CNM by collecting and pumping to the south, away from the restored wetland, most of the runoff from the CNM parking lot and by providing adequate detention and treatment for roof runoff and overflow runoff from the parking lot. Adverse ecological impacts are not expected to result from implementing the Proposed Action.

The potential human health effects of the proposed BSL-3 activities would be the same as those demonstrated for similar laboratories that are required to implement the guidelines established mutually by the Centers for Disease Control and Prevention (CDC) and the National Institutes of Health (NIH). The CDC and NIH define four levels of BSL work, in increasing levels of precaution - BSL-1, BSL-2, BSL-3, and BSL-4. BSL levels are specific combinations of work practices, safety equipment, and facilities that are designed to minimize the exposure of workers and the environment to infectious agents. BSL-3 applies to agents that may be transmitted by the respiratory route and that can cause serious infections. BSL-3 work at the APS would be limited to one BSL-3 hazard at a time. The quantity of BSL-3 samples at the APS at any time would be limited to 10 milliliters. Samples would either be pre-frozen or mounted in quartz capillaries. Human health information gathered from ANL-E's past experience with BSL-1 and BSL-2 laboratories, from the U.S. Bureau of Labor Statistics, and from anecdotal 
information in published reports, indicates that while laboratory-acquired or laboratoryassociated infections sometimes occur, they should be considered abnormal events because of their infrequency.

Radiological impacts from APS operations would not change and would remain very much below applicable standards and regulations. 
FINAL ENVIRONMENTAL ASSESSMENT

\section{ENHANCED OPERATIONS OF THE ADVANCED PHOTON SOURCE AT ARGONNE NATIONAL LABORATORY-EAST ARGONNE, ILLINOIS}

\section{INTRODUCTION}

This environmental assessment (EA) has been prepared by the U.S. Department of Energy (DOE) in compliance with the National Environmental Policy Act of 1969 (NEPA, 42 USC 4321 et seq.) to evaluate the potential environmental impacts associated with continued and enhanced operation of the Advanced Photon Source (APS), including modifications, upgrades, and new facilities, at Argonne National Laboratory-East (ANL-E) in DuPage County, Illinois (Figure 1.1). ANL-E is a Federal research and development facility operated by the University of Chicago for DOE. The proposed activities are intended to continue providing the nation's most brilliant x-ray beams for physical, chemical, biological, and materials research.

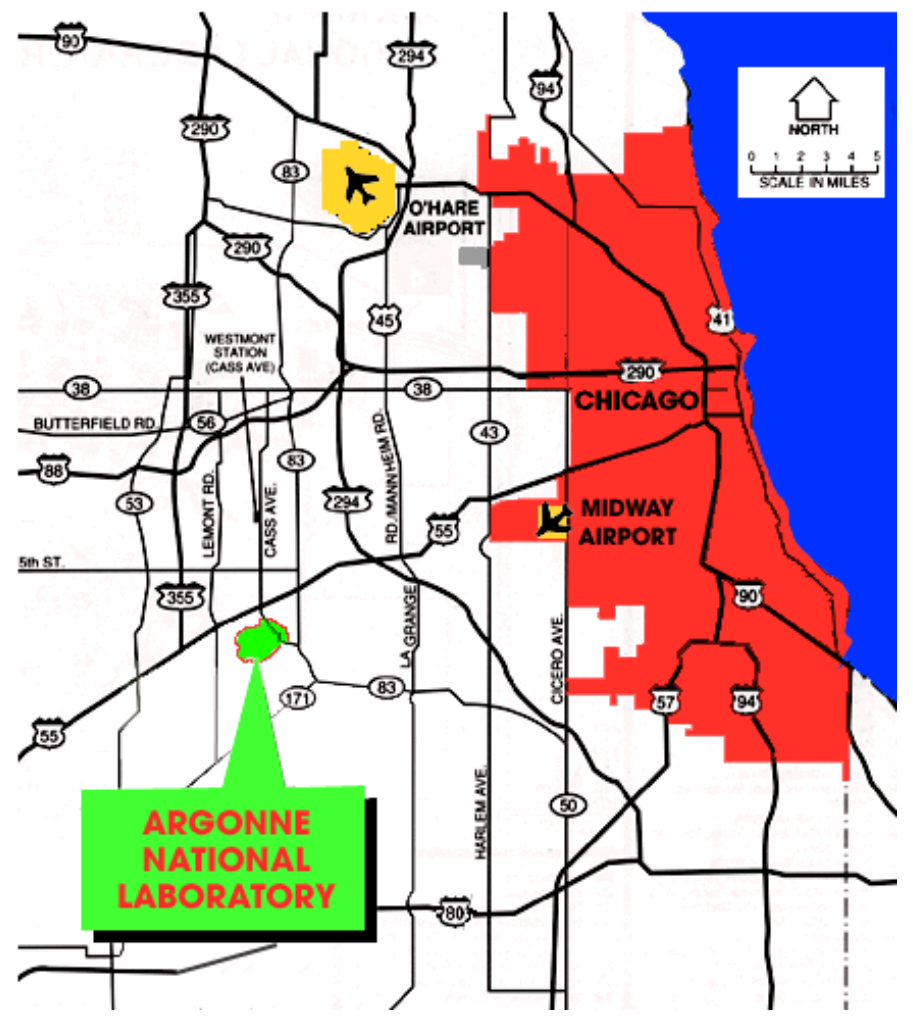

FIGURE 1.1 Location of Argonne National LaboratoryEast (Source: ANL 2002a) 
The APS at ANL-E (Figure 1.2) is a national synchrotron-radiation light source research facility. Members of the international synchrotron-radiation research community utilize highbrilliance X-ray beams from the APS to conduct forefront basic and applied research in the fields of materials science; biological science; physics; chemistry; environmental, geophysical, and planetary science; and innovative $\mathrm{x}$-ray instrumentation.

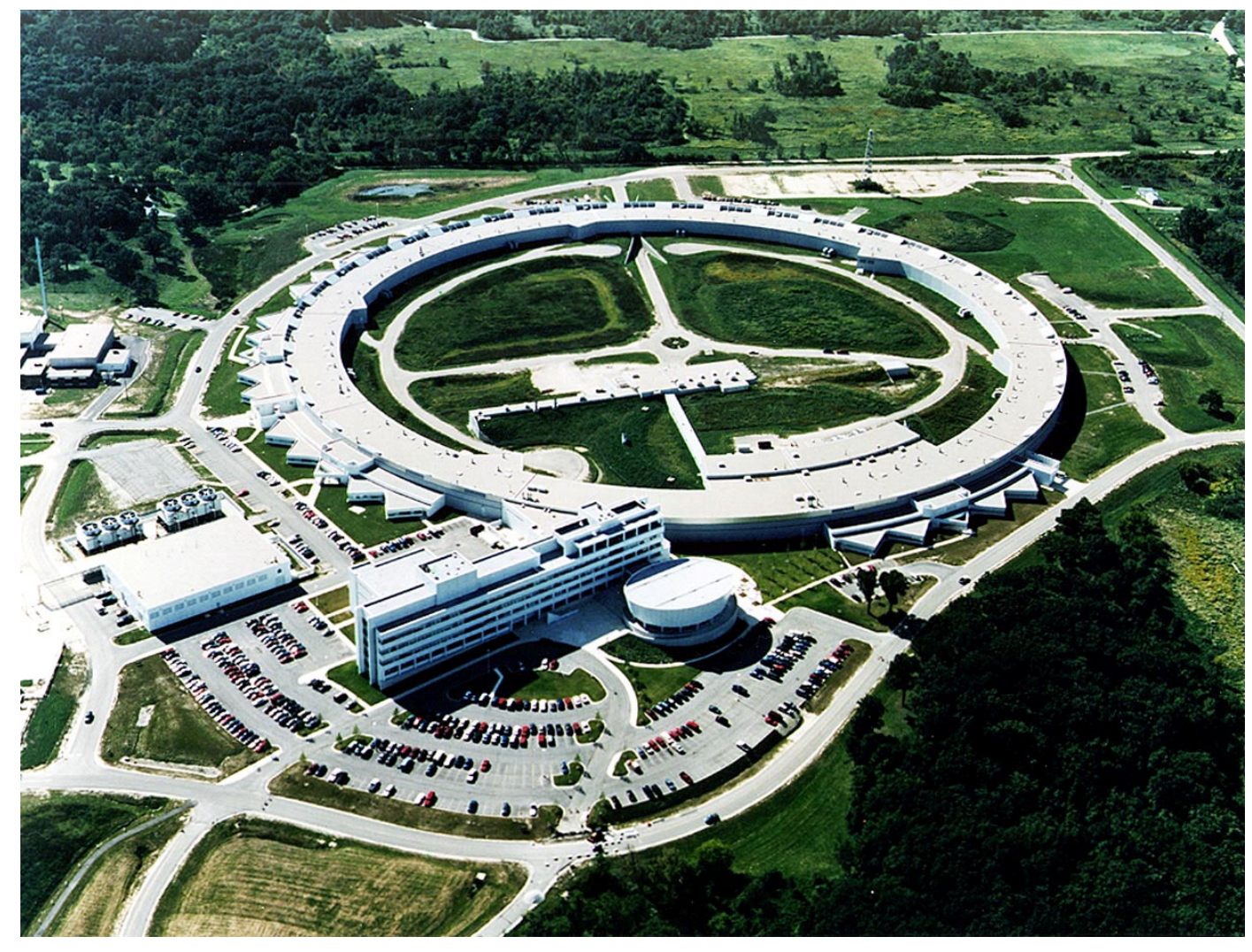

FIGURE 1.2 Advanced Photon Source, Argonne National Laboratory-East (Source: ANL 2002b) 


\section{PURPOSE AND NEED}

To meet its mission of sponsoring cutting-edge science and technology, DOE needs to continue to operate and enhance the scientific capabilities of the APS. Continued operation would include existing types of research activities as well as upgrades to systems at the APS.

Enhanced scientific capabilities would include the ability to conduct Biosafety Level-3 (BSL-3) research and nanoscale science research. 
2-2 


\section{THE PROPOSED ACTION AND THE NO-ACTION ALTERNATIVE}

\subsection{PROPOSED ACTION}

The Proposed Action is continued and enhanced operation of the APS facility at ANL-E (Figure 3.1). This action includes continued and evolving operations of the facility. Evolving operations include construction and operation of an additional experimental unit, a Center for Nanoscale Materials (CNM).

Construction of the APS was completed in 1996. DOE's report Environmental Assessment, Proposed 7-GeV Advanced Photon Source (DOE 1990) addressed the construction and operation of the APS. The APS has subsequently undergone minor modifications, including the expansion of the utilities building, construction of new beamlines and laboratory office modules (LOMs), and the establishment of a laboratory for working with biohazards.

\subsubsection{Continued Operations}

The APS is a third-generation synchrotron-radiation light source research facility at ANL-E (Figure 3.2). High-brilliance x-ray beams from the APS are used for research in numerous scientific fields, including biology, chemistry, physics, geology, materials science, nuclear science, and others. Under the Proposed Action and the No-Action Alternative, ongoing activities related to the operation and use of the APS would continue into the foreseeable future.

Operation of the APS entails the production of electron pulses that can be raised to an energy of $650 \mathrm{MeV}$, with a typical energy of $325 \mathrm{MeV}$ in the linear accelerator. Electron energies are raised to $7 \mathrm{GeV}$ as they are accelerated by electrical fields in the booster synchrotron. Following injection into the storage ring $(3,622 \mathrm{ft}[1,104 \mathrm{~m}]$ in circumference), the beam of electrons orbits the ring within a system of vacuum chambers and is guided and focused by electromagnets. The beam emits synchrotron radiation as it orbits the ring more than 271,000 times per second.

The storage ring is organized into 35 sectors, each of which is equipped to provide insertion device radiation and bending magnet radiation. Radiation is produced in the form of $\mathrm{x}$-ray beams that can be focused onto a target. Insertion device magnets and bending magnets are placed along the storage ring within each of the 35 sectors, creating 70 beamlines. Each sector is operated by a user team called a Collaborative Access Team (CAT). Beamlines are designed by the team to access radiation from the APS storage ring and are engineered to meet specific experimental needs; a variety of optical devices are used to adjust and focus the x-ray beam. Experiment stations and associated beamlines are constructed in the experiment hall. Assembled within the experiment station are detectors, equipment for analysis and characterization, and the 


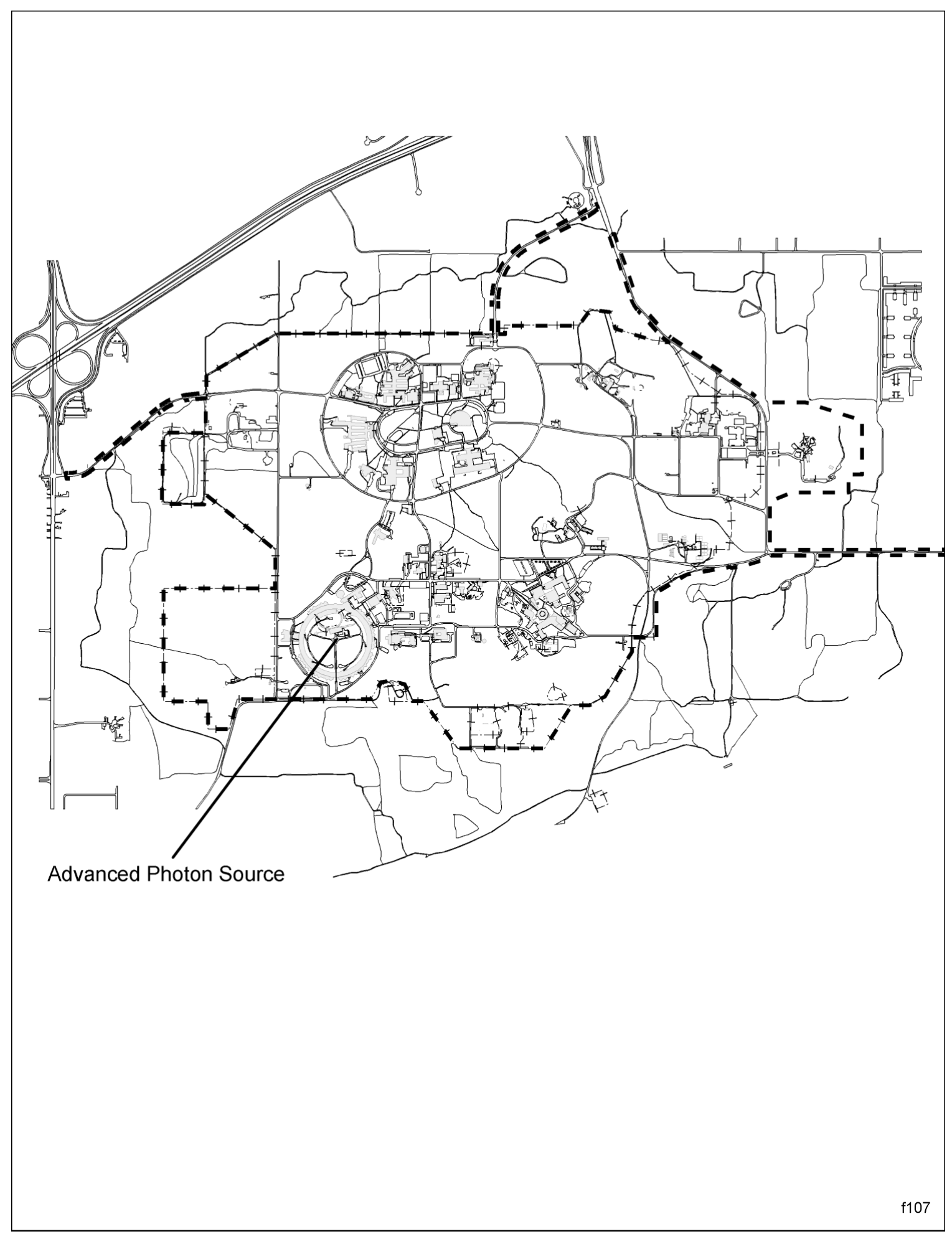

FIGURE 3.1 Location of the Advanced Photon Source at Argonne National Laboratory-East 


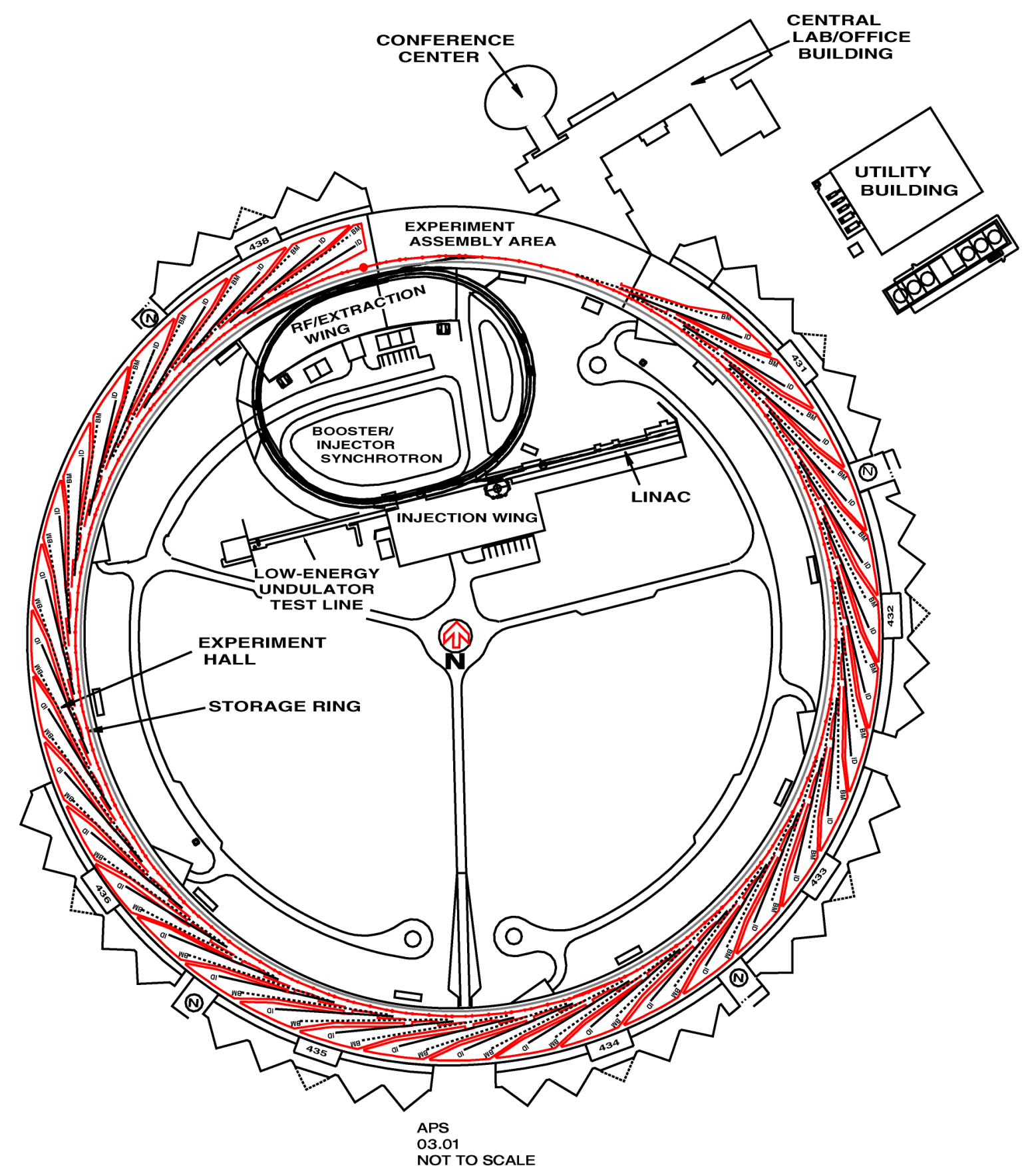

FIGURE 3.2 APS Accelerator Subsystems and Related Structures 
sample under investigation. Most of the experiments performed at the APS are for studying the microscopic structure of materials on atomic-length scales. The materials studies are of interest to physics, biology, chemistry, and materials science communities. Typical samples include materials of interest to the semiconductor and magnetic materials industries, protein crystals (usually of the order of 100 microns or less in size), polymer fibers, and geological materials studied at high pressures. Samples are exposed to various types and wavelengths of x-rays produced by the beamlines. Samples are generally prepared in advance off-site and shipped to the APS facility. Additional manipulation of experiment samples (such as mounting samples on holders or soaking samples in solutions to provide better imaging) is occasionally conducted in the LOMs or experiment stations and may include the use of laboratory chemicals. User laboratory and office space consists of LOMs located adjacent to the experiment hall, and each LOM is associated with a sector of the storage ring.

A Low-Energy Undulator Test Line (LEUTL) is located in the central area of the APS ring and is an extension of the linear acceleration/accelerator (LINAC). The LEUTL is used in the testing of new designs for undulator insertion devices and for research into a fourthgeneration light source producing ultra-high-brilliance synchrotron radiation.

Each year, a large number of scientists use the APS facilities (approximately 2,000 individual users in 2001). APS users include scientists from universities, industrial firms, national laboratories (including ANL-E), medical schools, and other research institutions. Scientific investigators use the APS either as members of CATs or as independent investigators. CATs, which consist of large numbers of investigators with common research objectives, are responsible for the design, construction, funding, and operation of their APS beamlines. CATs allocate a percentage of their beam time to independent investigators, either as individuals or groups. In 2002, 23 user teams had beamlines in use in 28 sectors of the experiment hall.

Facility expansion plans will add another cooling tower over the next five years to the three in the current APS infrastructure. Operation of the APS facility will continue to produce cooling-tower plumes, as well as sludge and blowdown water discharged from the cooling system. These effluents will continue to be handled in accordance with existing ANL-E and DOE policies.

The APS infield, that is, the center of the APS ring, contains a stormwater collection system that includes a series of interconnected collection basins. Storm water from the eastern half of the infield exits through a drain line and provides hydrologic input to Wetland $\mathrm{R}$, a wetland constructed southeast of the APS storage ring to mitigate wetland impacts from APS construction. Large fluctuations periodically occur in Wetland R inflow following storm events, indicating a potentially high degree of surface water runoff in the infield area and unrestricted outflow through the drain line. Under the proposed action, the non-native vegetation within the infield would be replaced with native species, and the drain line openings would be modified to allow the water collection system to function with low fluctuations in outflow.

Native upland species would be planted in upland areas of the infield to reduce surface runoff. Native species tolerant of saturated soils would be planted in low areas of the collection basins to attenuate flows through the basins. In addition, covers would be placed on the drain line 
opening in the infield collection basin. The covers would be designed to attenuate flows exiting the infield, thereby reducing the large fluctuations while allowing infield flows to continue to enter Wetland R.

\subsubsection{Enhanced Operations: BSL-3 Research Proposed for the APS}

Evolving operations at the APS would include the initiation of BSL-3 research (see Appendix A). BSL-3 research would include bench-scale studies of the structure of proteins, genetic materials, and toxins of indigenous or exotic agents with a potential for respiratory transmission, and which may cause serious and potentially lethal infection. Infection from BSL-3 agents does not spread easily to others, however, and preventive or therapeutic intervention is available (high individual risk but low community risk).

\subsubsection{Background}

The biological segment of the Consortium for Advanced Radiation Sources (BioCARS) facility at the APS currently allows researchers to collect data with a wide range of samples by standard monochromatic crystallography, Multi-wavelength Anomalous Diffraction (MAD), Laue crystallography, and time-resolved crystallography (BioCARS 2002). Only a small percentage of the samples that have come to BioCARS in the past are hazardous to any degree. About $1 \%$ of the total samples are categorized as BSL-2 hazards, or about 3 or 4 samples a year. The most frequent BSL-2 sample studied at BioCARS is the human rhino virus (HRV), the virus that causes the common cold.

\subsubsection{Proposed Action}

Research on small BSL-3 samples would be conducted in the existing BioCARS facility. BioCARS is currently the only facility at ANL-E designed and constructed for work with samples classified as BSL-2 or BSL-3 agents. All experimental stations and control areas within the BioCARS experimental area can be operated in BSL-2 and BSL-3 modes. The existing BioCARS facility was constructed for, but never used for, BSL-3 research. The standard and specific safety practices, the required safety equipment (primary barriers), and the laboratory facility design (secondary barriers) for research with BSL-3 agents are described in the Centers for Disease Control and Prevention/National Institutes of Health (CDC/NIH) guidelines, Biosafety in Microbiological and Biomedical Laboratories (CDC 1999). The BioCARS implementations of these practices, as well as the engineering and administrative controls, are described in the BioCARS BSL-3 Standard Operating Procedure (SOP) that is part of the CARS Safety Plan (University of Chicago 2003).

The new BSL-3 research would not involve culturing of BSL-3 agents, because users of the BioCARS would use BSL-3 facilities at their home institution for that task. After the agent has been cultured and purified, the BSL-3 material is crystallized. The crystallization process orders many copies of the agent into a three dimensional array. Crystals of proteins and viruses 
are typically small, with any dimension exceeding $1 \mathrm{~mm}$ being extremely rare. Sizes on the scale of $0.1 \mathrm{~mm}$ are much more common. Only after the samples have been crystallized are they suitable for studies in the x-ray beams provided at BioCARS. Although culturing of the organisms would not take place at BioCARS, the crystallization process may, as some crystals are too fragile to transport.

The key engineering controls of the BioCARS facilities (Figure 3.3) that ensure safe operations at BSL-3 are (1) directed air flow, (2) a Class II, type B2 biological safety cabinet, (3) high-efficiency particulate air (HEPA) filters, and (4) a series of rooms in the facility that allow the isolation of the BSL-3 experiments from the rest of BioCARS and the APS. All air exhausted from the BSL-3 facility passes through HEPA filters that remove $99.97 \%$ of the particulates with a diameter of $0.3 \mu \mathrm{m}$ or larger.

\subsubsection{Scale and Scope}

The proposed BSL-3 research at BioCARS differs from most other BSL-3 facilities outside of ANL-E in both scale and scope. Work at BioCARS involves tiny crystals making up a total sample volume of less than $10 \mathrm{~mL}$ on-site at any time. These samples are used either frozen at liquid nitrogen temperatures or sealed in capillaries. In either case, the potential for aerosol creation is minimized or eliminated completely. The scope of the proposed research would be limited to the study of one BSL-3 hazard at a time. On the basis of the current level of BSL-2 research, it is expected that there would be on the order of one or two BSL-3 experiments per year, each taking less than a week. In the crystallographic studies related to disease, the interest is in studying the interaction of a drug with its target protein. The target proteins themselves are usually nonhazardous, with the result that most of the research can be done without biohazards. It is only in the case where the structure of the entire agent, such as a virus, needs to be studied that researchers are required to use BSL-2 or BSL-3 samples.

\subsubsection{Oversight}

The ANL-E Laboratory Director established the Institutional Biosafety Committee (IBC) on October 2, 2002, to oversee and manage the site-wide biosafety program. The BSL work would be subject to IBC oversight. BioCARS works with the IBC to ensure that the BSL-3 Standard Operating Procedures (SOP) (University of Chicago 2003) are adequate for operations. The SOP establishes the following constraints on work done at BioCARS:

- Administrative limits on operations, such as a limit on the total volume of material $(<10 \mathrm{~mL})$ and a limit on the use of samples to pre-frozen or mounted in quartz capillaries.

- A prohibition on culturing microorganisms, and

- A prohibition against long term storage of BSL-3 samples. 


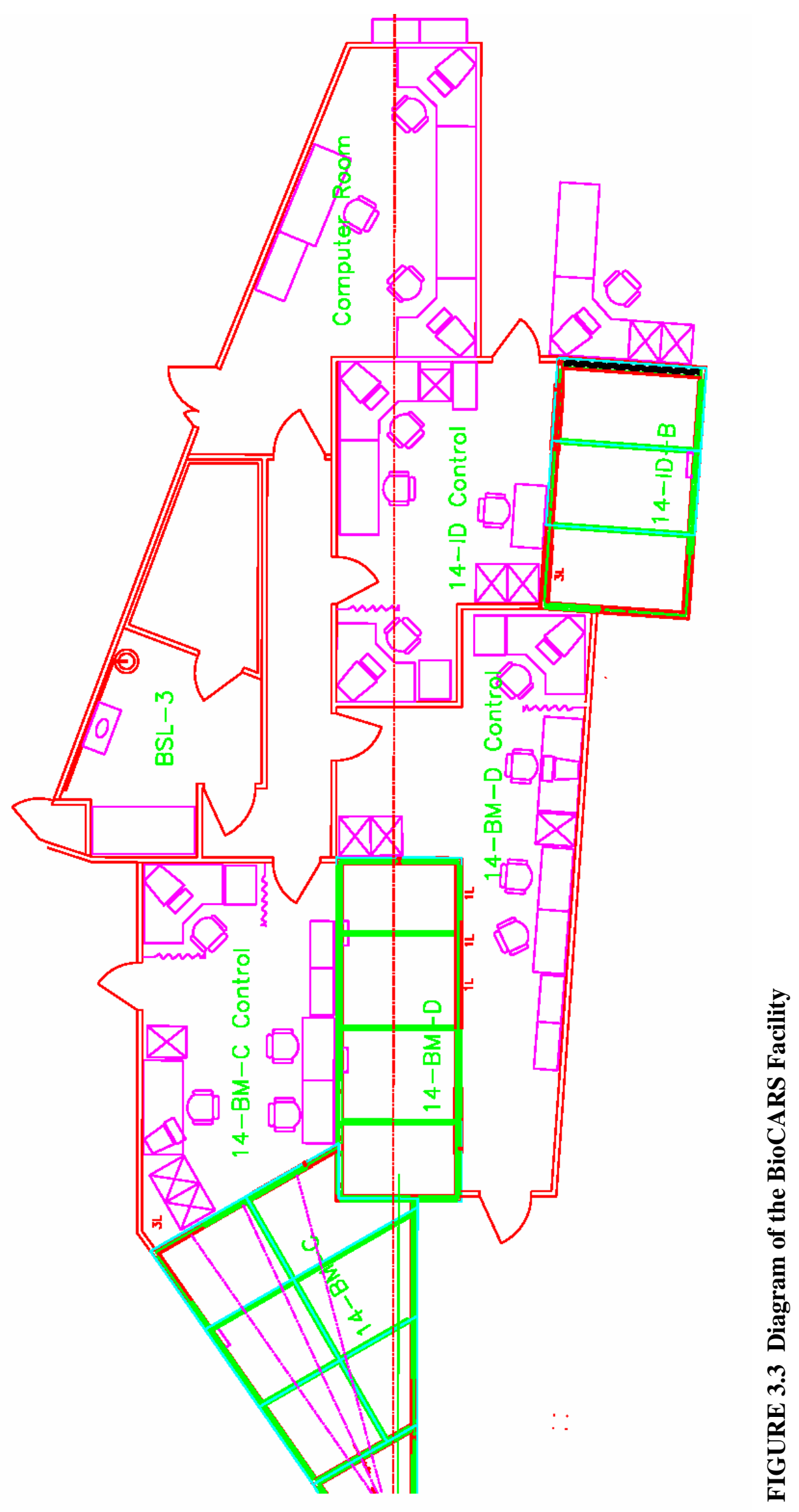


In addition, the SOP specifies the procedures that must be followed by both staff and users of the facility. The IBC must approve all experiments involving BSL-2 and BSL-3 materials as part of its oversight responsibilities. A process for reviewing and modifying the BioCARS BSL-3 SOP on a regular basis is in place and is used to ensure all current Federal regulations are followed.

\subsubsection{Select Agents}

Select agents, as specified in 42 CFR 72.6, Appendix A, require additional regulation. Select agents are biological agents of human disease whose transfer or receipt requires a facility to be registered with the CDC under 42 CFR Part 72.6. Select agents have historically been associated with weapons production efforts and thereby require a heightened level of security. Regulation of select agents comes as a response to the threat of bioterrorism and attempts to limit the distribution of such agents while allowing their scientific use to, for example, develop vaccines. There are currently no proposals for working with select agents at BioCARS, and BioCARS is currently not approved for using any select agent. However, work with select agents at BioCARS in the future has not been precluded. Any future proposal for working with select agents at BioCARS would require special oversight by the IBC and the DOE Field Office, as spelled out in DOE N 450.7, 42 CFR 73, 7 CFR 331, and 9 CFR 121. If a proposal were made in the future to work with select agents at BioCARS, the proposal would be evaluated at that time to determine what NEPA review would be required.

\subsubsection{Shipping}

Shipping and receiving of all samples to and from BioCARS is supervised by the appropriate personnel from the BioCARS, ANL-E, and the user's institution. Samples of all types must be brought to BioCARS according to the appropriate U.S. Department of Transportation (DOT) regulations: infectious agents must be packaged as specified in 49 CFR 173.196, and shipping personnel are required to be trained. The packages used are commercially available and have been certified by the manufacturer as required by DOT. The package types have undergone extensive drop, crush, and other accident condition testing before the DOT determined what packaging was appropriate to ensure safe transport of these types of samples. A typical package is shown in Figure 3.4. Sample packages arrive through ANL-E Receiving and depart through ANL-E Shipping. All transport of samples on-site to and from the APS is carried out according to the most current requirements of the ANL-E Hazardous Materials Transportation Manual. The samples are in sealed packages except when they are in use at the APS.

\subsubsection{Waste}

Waste from the facility is disinfected and collected for disposal with existing ANL-E

protocols and personnel. Currently the decontaminated waste is shipped to an off-site vender for 


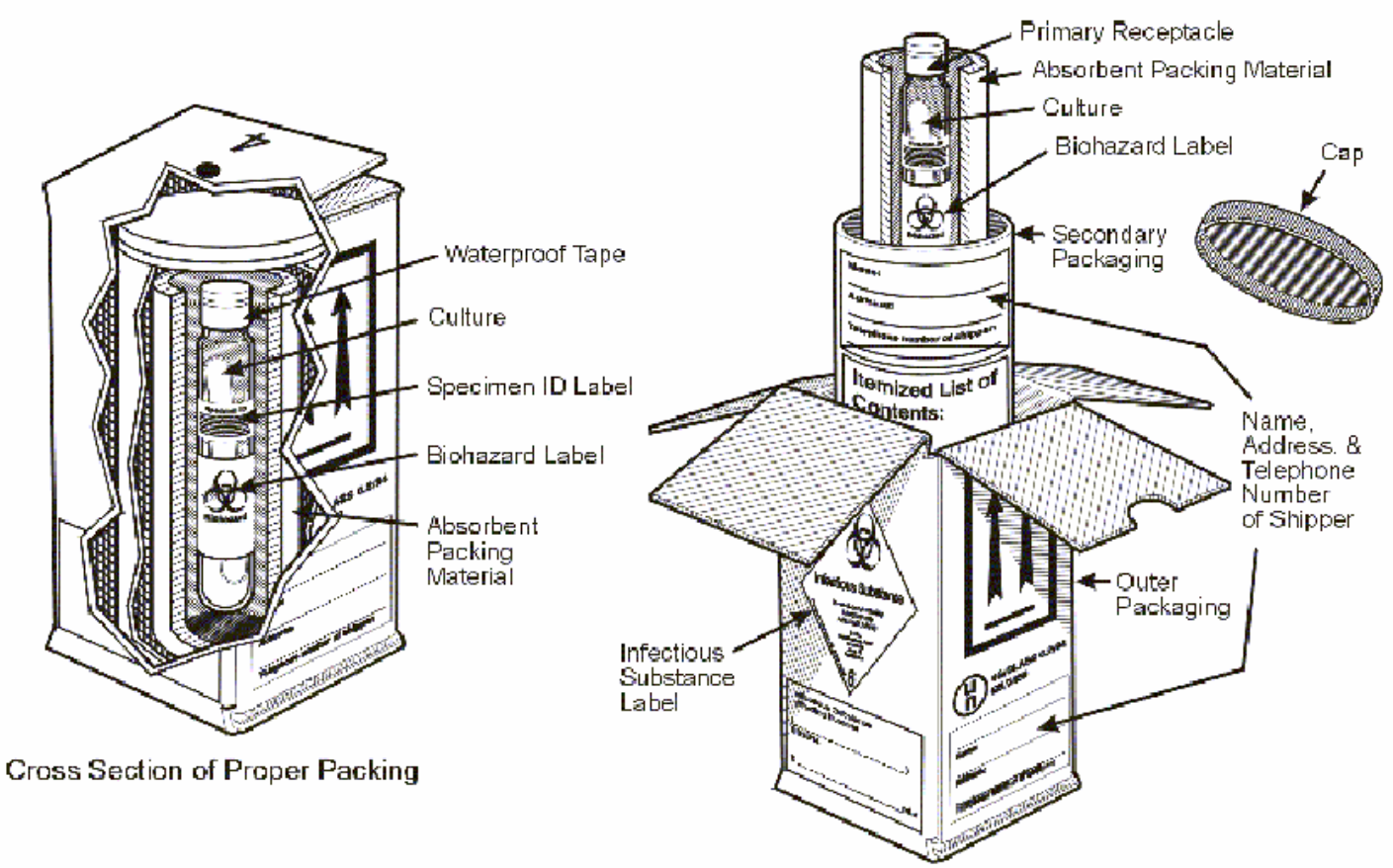

FIGURE 3.4 Diagram of a Typical Package Used to Ship Biological Materials to and from the BioCARS Facility

incineration. Because of the limited quantities of materials involved and the fact that BSL-3 research will displace other experiments at the facility that generate similar quantities of waste, the addition to the waste stream caused by the proposed action would be negligible (Appendix A).

\subsubsection{Enhanced Operations: Construction and Operation of a Nanoscale Science Facility}

The CNM facility would be constructed to house research activities on nanoscale science (Figure 3.5). The facility would reflect the diverse research of the collaboration between the APS and the ANL-E Materials Science and Chemistry Divisions, which is directed toward a major new thrust in nanoscience. The CNM facility would be located along the west side of the APS facility and connected to the experiment hall adjacent to a sector of the APS dedicated to x-ray beamlines in support of the CNM (Figure 3.5). A new LOM (LOM-437) would also be constructed immediately north of the CNM facility, adjacent to the APS experiment hall.

Research on nanoscale materials at the CNM facility would include lithographic patterning, nanoscale material fabrication using deposition and etching equipment, metrology, compositional and structural determination, and physical phenomena characterization. The CNM would include cleanrooms for wet chemical processing, laboratories for chemical and physical measurements, computational laboratories, offices, and conference rooms. Lithographic 


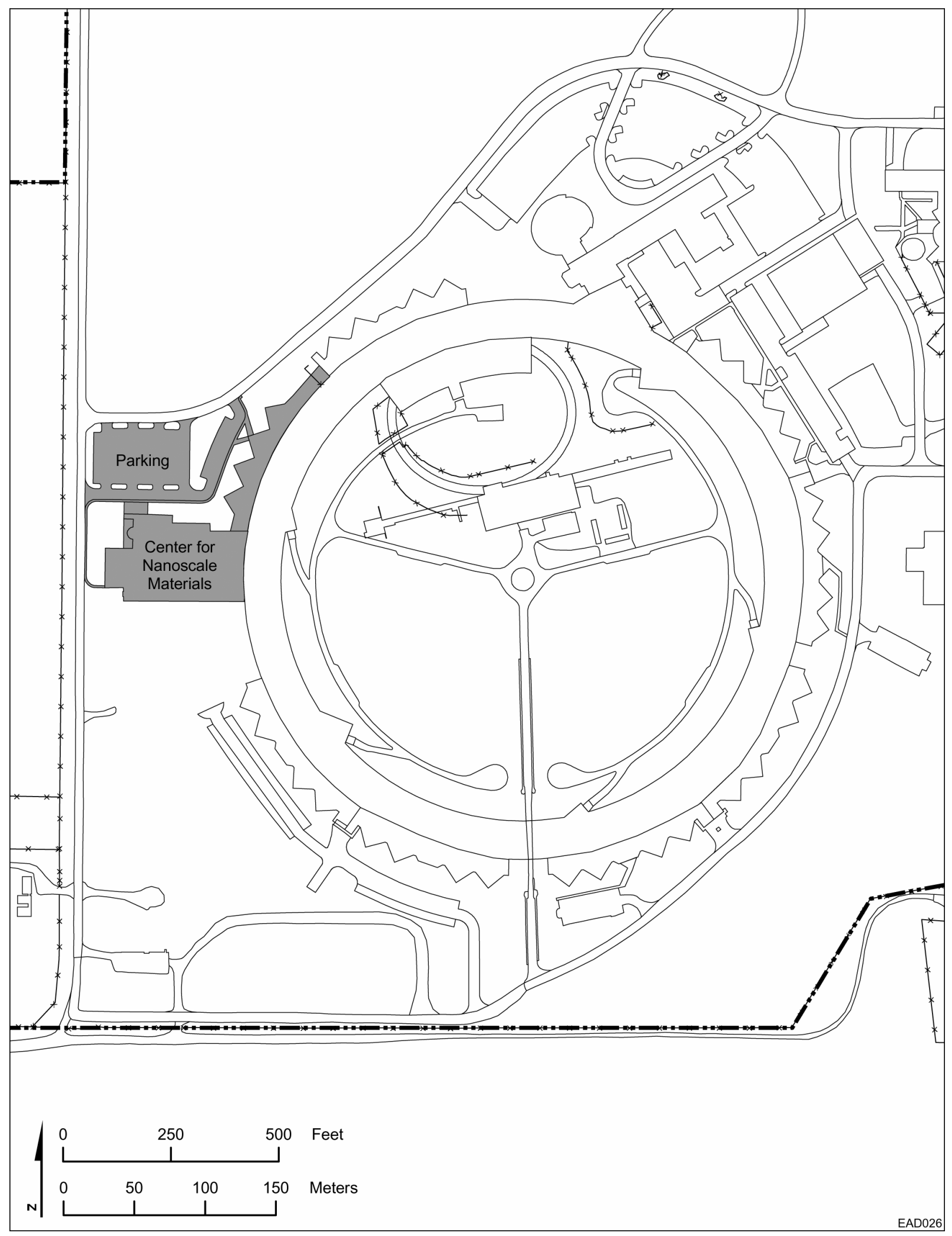

FIGURE 3.5 Proposed Construction at the Advanced Photon Source 
self-assembly techniques utilizing biological materials would be carried out in BSL-2 laboratories, when appropriate. These BSL-2 laboratories would be designed as microbiological laboratories for conducting bench-scale research with biological agents. They would utilize safety precautions such as splash shields, face protection, gowns, gloves, and handwashing sinks. No work with select or etiologic agents would be conducted in the CNM.

The CNM would provide full-support facilities for lithographic patterning, including cleanrooms for wet chemical processing. Special deposition and etching facilities would be used for the fabrication of nanoscale materials and for transferring the patterns produced by lithography, chemical self-assembly, or polymer templating to actual structures of the material of interest. The CNM would house the large-scale deposition and etching equipment required to establish the special techniques needed to fabricate nanostructured materials. Several dedicated chambers would be provided to alleviate issues concerning contamination, which often limit one system to deposition or etching of a single or limited range of materials. The deposition chambers and relevant metrology tools would be effectively clustered according to utility and operational requirements, such as for the provision of source gases, use of scrubbers to clean exhaust air, and the collection and disposal of waste effluent in a safe and efficient manner. A more detailed discussion of CNM research under the Proposed Action is included in Appendix B.

The new facility would include $48,000 \mathrm{ft}^{2}\left(4,459 \mathrm{~m}^{2}\right)$ (net) to $100,000 \mathrm{ft}^{2}\left(9,289 \mathrm{~m}^{2}\right)$ (gross) of floor space in two stories and would consist of five major components: (1) conventional facilities, (2) fabrication facilities, (3) instruments for characterization, (4) highthroughput computational facilities, and (5) new x-ray beamlines. Approximately 10,000 $\mathrm{ft}^{2}$ $\left(929 \mathrm{~m}^{2}\right)$ would be dedicated to cleanroom areas, a similar amount to other research laboratories, up to $20,000 \mathrm{ft}^{2}\left(1,856 \mathrm{~m}^{2}\right)$ to offices and conference areas, and the remainder to support facilities. The footprint of the facility would be approximately $50,000 \mathrm{ft}^{2}\left(4,645 \mathrm{~m}^{2}\right)$. The building footings will be $4 \mathrm{ft}(1.2 \mathrm{~m})$ below the proposed finished floor elevation of $744 \mathrm{ft}$ $(227 \mathrm{~m})$. The conventional facilities would make use of the APS's large utility infrastructure. A new 1-MW (3.5 MMBtu/h) natural-gas-fired boiler for humidification would be associated with the CNM complex. This boiler would not be operated during the summer and would normally operate at less than peak capacity. Emissions from cleanrooms would exit the facility through scrubbers or high-efficiency particulate air (HEPA) filters, which would reduce emissions by more than $99 \%$.

A Stormwater Pollution Prevention Plan (SPPP) would be prepared prior to construction to address potential impacts to surface water quality from construction of the CNM facility. During construction of the CNM facility, stormwater discharges would be covered by the Illinois State General Stormwater Permit (ILR 10), upon notification to the Illinois Environmental Protection Agency (IEPA) through the Notice of Intent for such activity. Compliance with the general provisions of the permit would require preparation of an SPPP for the project site, prepared in accordance with Part IV of the general provisions of NPDES Permit ILR 10.

Before construction activities began, sediment and erosion control measures would be put in place to mitigate the potential impacts of the construction of the proposed facility on surface water resources downgradient of the project site. Approved ANL-E construction practices, such 
as sediment fences, compaction, contouring, and sediment retention basins would be used to minimize potential runoff, erosion, and sedimentation. During construction of the CNM facility, stormwater would continue to be routed through the stormwater drainage system to the stormwater collection basin serving the western portion of the APS site, which would serve as a sediment retention basin. Although turbidity in stormwaters would settle out in the collection basin, discharges from this basin would be monitored to ensure that impacts to downstream surface waters, including Wetland 302, are avoided.

After construction of the CNM facility and parking area, all disturbed soils would be landscaped and revegetated to retard runoff and control erosion. Sediments in runoff would be routed through a collection basin, which would reduce sediment load. In compliance with Executive Order 13148, Greening the Government through Leadership in Environmental Management, native plant species would be used for landscape plantings on the CNM facility site. Executive Order 13148 directs federal agencies to implement environmentally sound landscaping practices, such as the use of native species, to reduce adverse impacts to the natural environment.

During operation of the CNM facility, controls for the management of stormwater flows from the CNM site would be put in place to reduce flow fluctuations and the amplitude of peak flows and to remove or filter contaminants to meet water quality criteria that are protective of wetlands, including wetland communities and component biota. Stormwater runoff from all existing roof drains and land surfaces that would not be disturbed by construction (including the existing parking lot near LOM 438) would continue to be directed to the location of the existing culvert near the intersection of Rock Road and Kearney Road. This runoff would continue to enter the small stream and subsequently enter Wetland 302. Flow from all new roof drains associated with the CNM facility and new LOMs, as well as landscaped areas, would also be directed to that location and would enter Wetland 302. Runoff from all existing and new roof drains would first enter a new stormwater detention basin, which would temporarily detain stormwater and attenuate flow peaks prior to release. Roof drains from the CNM facility would enter a detention basin constructed east of the CNM parking area. This basin would have a capacity of approximately $10,500 \mathrm{ft}^{3}\left(297 \mathrm{~m}^{3}\right)$, a surface area of approximately 2,625 $\mathrm{ft}^{2}$ $\left(243.8 \mathrm{~m}^{2}\right)$, and would be $4 \mathrm{ft}(1.2 \mathrm{~m})$ deep. Vegetation planted within the basin would consist of a mixture of native herbaceous species tolerant of inundation as well as dry periods, such as prairie cord grass (Spartina pectinata), marsh blazing star (Liatris spicata), mountain mint (Pycnanthemum virgianum), or sneezeweed (Helenium autumnale). In addition, a replaceable filter (such as Fossil Filter ${ }^{\mathrm{TM}}$ ) would be included in the drainage system outlet to the receiving stream, to further lower contaminant concentrations. This filter would remove 69 to $92 \%$ of the petroleum-based oil and grease (KriStar undated).

Under the proposed action, a parking area about 40,000 $\mathrm{ft}^{2}\left(4,000 \mathrm{~m}^{2}\right)$ would be constructed adjacent to the north side of the CNM facility at the intersection of Kearney and Rock Roads, in the area currently occupied by a stormwater collection basin. Runoff from the parking area would enter a new stormwater collection basin adjacent to the parking area. The basin would have a capacity of approximately $3,033 \mathrm{ft}^{3}\left(85.89 \mathrm{~m}^{3}\right)$, would be $4 \mathrm{ft}(1.2 \mathrm{~m})$ deep, and would have a surface area of about 1,054 $\mathrm{ft}^{2}\left(97.91 \mathrm{~m}^{2}\right)$. Parking lot runoff would be pumped from this collection basin away from Wetland 302. A 200-gpm (760 L/min) pump 
would continuously pump the collected stormwater, which would be directed south along Kearney Road by means of a 10-in. $(25-\mathrm{cm})$ diameter drain line. The drain line would discharge to a grassy swale that would be constructed along Kearney Road. The swale would filter out contaminants, increase infiltration, and reduce flow velocities. The swale would be $200 \mathrm{ft}(60 \mathrm{~m})$ long, with a longitudinal slope of 2-3\%, and it would be graded to create sheet flow. It would be constructed with a trapezoidal cross section, with 3:1 side slopes (horizontal to vertical). The swale bottom would be $2-8 \mathrm{ft}(0.6-2 \mathrm{~m})$ wide, and the total swale width would be at least $20 \mathrm{ft}$ $(6 \mathrm{~m})$. Check dams, $1 \mathrm{ft}(0.3 \mathrm{~m})$ in height, would be placed along the swale every $50 \mathrm{ft}(15 \mathrm{~m})$, with the first located $20 \mathrm{ft}(6 \mathrm{~m})$ from the point of inflow. The swale would be designed for a 2-year, 24-hour storm event, which would result in a maximum flow rate of $1 \mathrm{ft} / \mathrm{s}(0.3 \mathrm{~m} / \mathrm{s})$, and a maximum water depth of 4 in. $(10 \mathrm{~cm})$. It would be able to accommodate flows from a 100-year, 24-hour storm. The swale would be planted with prairie cord grass (Spartina pectinata), which would be inspected annually and replanted where growth was sparse or absent.

The pumped stormwater runoff would exit the ANL-E site at the south fenceline. Overflow from the collection basin would enter the stream north of Rock Road. Periodic maintenance would be performed to ensure proper functioning of the detention basins. Maintenance would include replanting vegetation in areas of reduced growth, removing accumulated sediments, and repairing areas of eroded soil.

In addition to the proposed parking configuration, three alternative parking options are considered in this EA. More detailed discussions on those alternative parking lot options are provided in Appendixes D and E. Under parking alternative B, the parking area location would be the same as under the proposed option; however, bioretention swales would be incorporated into the CNM facility parking area to receive stormwater flows from this parking area and adjacent areas, and stormwater would not be routed away from Wetland 302. The bioretention swales would be located between parking rows and along the western edge of the parking lot. Stormwater runoff would infiltrate through the bioretention swale vegetation and soil. Drainage from the bioretention swales would be collected in an underground system of perforated drainage pipe. The bioretention swales would temporarily retain stormwater flows, permit a gradual release of water, and filter out and degrade contaminants. The design capacity for the bioretention swales would be to treat a mean 6-hour storm event, and they would be sized to total $7 \%$ of the parking area. The surface of the bioretention swales would be recessed below the parking surface and would allow ponding of water to a depth of 6 in. $(15 \mathrm{~cm})$. Overflow would be directed to the underground drainage system.

The surface of the bioretention swales would consist of a 3-in. (7.6- $\mathrm{cm})$ thick shredded hardwood mulch layer, placed above a 4-ft $(1.2-\mathrm{m})$ thick layer of loam-textured planting soil. The soil would have a clay content of 10 to $25 \%$, organic matter content of 1.5 to $3 \%$, a $\mathrm{pH}$ range of 5.5 to 6.5 , and an infiltration rate greater than 0.5 in. $(1.25 \mathrm{~cm})$ per hour. An 18 -in. $(0.5-\mathrm{m})$ layer of gravel or sand would be placed below the soil and would contain the drainage pipe. Vegetation planted in the bioretention swales would be a mixture of native herbaceous species tolerant of inundation as well as dry periods, such as prairie cord grass (Spartina pectinata), switch grass (Panicum virgatum), marsh blazing star (Liatris spicata), and mountain mint (Pycnanthemum virgianum), or New England aster (Aster novae-angliae). Periodic maintenance would be performed to ensure proper functioning of the bioretention swales. Maintenance would 
include removal of sediments, addition of mulch where needed, and replanting of vegetation in areas of reduced growth. The mulch layer would be removed and replaced annually, and soils and vegetation would be replaced every 5 years.

Following infiltration through the bioretention swales, runoff from the parking area would enter an underground drainage system, which would also receive the releases from the new retention basin for roof runoff. The combined flows within this drainage system would be directed to the location of the existing culvert under Rock Road, and enter the stream flowing into Wetland 302.

Under parking alternative $\mathrm{C}$, the main parking area would be located approximately $400 \mathrm{ft}(100 \mathrm{~m})$ south of the CNM facility. This parking area would be about $37,000 \mathrm{ft}^{2}$ $\left(3,400 \mathrm{~m}^{2}\right)$ in size. Stormwater runoff from this parking area would drain to the south along Kearney Road. A grassy swale would be constructed along Kearney Road to filter out contaminants, increase infiltration, and reduce flow velocities. The parking area runoff would then exit the ANL-E site at the south fenceline. A pedestrian walkway from the parking area to the CNM facility would also be constructed. A smaller parking area, about $16,000 \mathrm{ft}^{2}\left(1,500 \mathrm{~m}^{2}\right)$ in size, would be located on the north side of the CNM facility. This smaller parking area would accommodate handicap and other special needs parking. Stormwater runoff from this smaller parking area would drain to the detention basin for collection of roof runoff, and subsequently to the receiving stream north of Rock Road.

Under parking alternative $\mathrm{D}$, the main parking area would be located south of the CNM facility, as in alternative $\mathrm{C}$ above, however it would consist of a multi-story parking facility. The footprint of this facility would be about $28,000 \mathrm{ft}^{2}\left(2,600 \mathrm{~m}^{2}\right)$ with about 80 parking spaces per floor. Either two or three floors would be constructed, with the top floor designed as exposed parking. Stormwater runoff from this parking area would drain to the south along Kearney Road. A bioswale would be constructed along Kearney Road to filter out contaminants, increase infiltration, and reduce flow velocities. The parking area runoff would then exit the ANL-E site at the south fenceline. A pedestrian walkway from the parking facility to the CNM facility would also be constructed. A smaller parking area would be constructed on the north side of the CNM, as for alternative $\mathrm{C}$.

\subsubsection{Schedule and Manpower}

Construction of the CNM would take approximately 2 years and require a workforce of up to 50 construction workers. Materials used to construct the facility would include fill, asphalt, structural steel, and concrete. Estimated construction costs for the CNM are on the order of $\$ 25$ million. The CNM would have a permanent staff of 60 , with 130 offices and a total occupancy of 150 . 


\subsection{NO-ACTION ALTERNATIVE}

Under the No-Action Alternative, current APS operations would continue. The types of research presently conducted at the facility, as well as present materials and waste handling procedures, would continue. Maintenance of accelerator and support systems, including replacement of system components, as well as minor infrastructure modifications required for continued operations, would occur. In addition, actions to address impacts to Wetland R would be implemented. However, operational changes, such as the initiation of BSL-3 research, would not occur, and the new CNM research facility would not be constructed under the No-Action Alternative. 


\section{AFFECTED ENVIRONMENT}

The APS is located in the southwestern quadrant of ANL-E (Figure 3.1), which is located in DuPage County, Illinois, $27 \mathrm{mi}(43 \mathrm{~km})$ southwest of downtown Chicago (Figure 1.1).

\subsection{SITE DESCRIPTION}

The terrain of ANL-E is gently rolling, partial wooded, former prairie and farmland. The site is divided into a number of campus-like areas that contain the various research and development facilities of this multipurpose laboratory.

\subsection{GEOLOGY AND SOILS}

The geology of the ANL-E area consists of about $100 \mathrm{ft}(30 \mathrm{~m})$ of glacial drift on nearly horizontal bedrock consisting of Niagran and Alexandrian dolomite approximately $200 \mathrm{ft}(60 \mathrm{~m})$ thick with an irregular eroded upper surface. The upland soils of the site were derived from glacial till and are primarily well drained, with low organic content and a large water capacity. Along the intermittent streams and upland depressions, soils are poorly drained, with high organic matter content and a large water capacity.

No tectonic features within $62 \mathrm{mi}(135 \mathrm{~km})$ are known to be seismically active. The few recent minor earthquakes that have occurred in northern Illinois are presumed to have been caused by isostatic adjustments of the earth's crust in response to glacial loading and unloading. The nearest areas of seismic activity are located in the St. Louis area (New Madrid fault zone) and along the southern Illinois-Indiana border (Wabash Valley Fault zone), each located about $200 \mathrm{mi}(322 \mathrm{~km})$ from ANL-E. Ground motions for the ANL-E site are expected to be minimal. Peak accelerations of $10 \%$ of gravity (the approximate threshold of major damage) may occur once in approximately 600 years ( -250 to +450 error range) (Golchert et al. 2001).

Soil activation from APS operation is negligible (Moe 1991), because the main activation component of the radiation proceeds in the forward direction relative to the beam; therefore, it is completely absorbed by the collimators and beam stops. The scattered photons are incapable of activating soil. Potential soil contamination by deposited airborne radionuclides would be negligible, too, because of the small amount of air emission rates (less than 7.4 Ci in year 2001 [Golchert and Kolzow 2002], see Section 4.9.1 for more discussion) and the fact that the radionuclides released $(\mathrm{C}-11, \mathrm{~N}-13$, and $\mathrm{O}-15)$ are short-lived, with half-lives less than 20 minutes. Even if airborne radionuclides would have a chance to deposit to surface soil, they would decay away shortly after deposition. 


\subsection{WATER RESOURCES}

\subsubsection{Surface Water}

The ANL-E site lies above the bluffs bordering the Des Plaines River valley, which was formed by glacial meltwater draining the area that is now Lake Michigan about 11,000 to 14,000 years ago. This valley contains the Des Plaines River, the Chicago Sanitary and Ship Canal, and the Illinois and Michigan Canal. The ANL-E site is drained by Sawmill Creek (average flow of approximately 7.5 million gal/day [28 million L/day]). A number of unnamed intermittent tributaries of Sawmill Creek drain the area surrounding the northern portion of the APS site. These tributaries arise from wetlands located west and north of the APS site. The southern portion of the APS site drains south to the Des Plaines River. Surface water drainage patterns of the APS site and surrounding areas are shown in Figure 4.1.

The APS facility does not include sanitary or laboratory wastewater treatment facilities; sanitary and laboratory wastewaters are separately collected, treated, and discharged by the ANL-E sanitary wastewater treatment plant and the ANL-E laboratory wastewater treatment plant. Therefore, at the APS site, only stormwater discharges have the potential to affect surface water.

Operation of the APS facility as currently configured includes control of stormwater. Stormwater flow from the APS site is illustrated in Figure 4.1. For the purposes of discussion, these drainages have been grouped into (1) drainage from the northern portion of the APS into Wetland 302, (2) drainage from the eastern portion of the APS, (3) drainage into Wetland R, (4) drainage to the south, and (5) drainage from the northwestern portion of the APS into Wetland 302.

Stormwater from the northern portion of the APS site, including parking lots near the main building, flows west into a drainage channel that empties into the downstream end of Wetland 302. This drainage system carries runoff from grassy areas and parking lots, as well as wooded areas beyond the APS site. Water in this channel is retarded by natural vegetation and by a small riprap dam. This retardation allows some infiltration of water and assists with settling of particulates and degradation and removal of organic material. However, this end of Wetland 302 is somewhat degraded.

Stormwater from the eastern portion of the APS is routed to a vegetated channel that discharges through NPDES Outfall 115 at the site boundary southeast of the APS site. This drainage flows toward the Des Plaines River through the Waterfall Glen Forest Preserve. The Outfall 115 system drains the APS facility and associated roadways and loading docks. This discharge also includes drainage from areas beyond the APS site, including Buildings 314, 315, and 316 complex storage areas, loading docks, and cooling water discharges. In 2000, toxicity tests showed that discharges from Outfall 115 were acutely toxic to the water flea but not to the fathead minnow during the months of July and August. This toxicity was associated with chlorinated cooling water discharges and other drainage from Buildings 314 through 316; these 


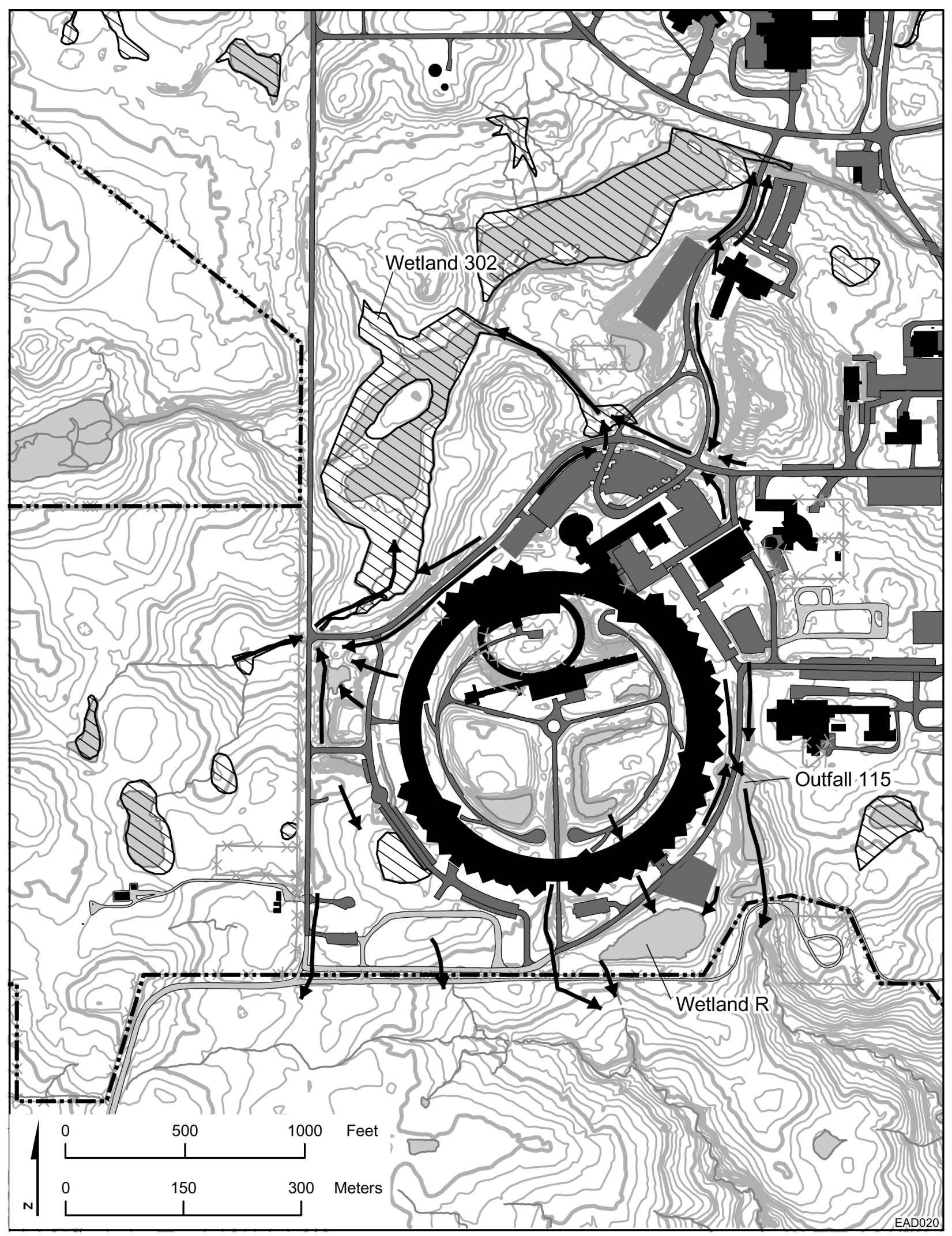

FIGURE 4.1 Surface Drainage Patterns for the APS Site (arrows indicate direction of flow) 
discharges were rerouted during 2000 and 2001 to the ANL-E laboratory wastewater treatment plant (Golchert et al. 2001). Stormwater from the eastern portion of the APS site drainage would not impact the water quality of receiving waters.

Stormwater from the southern portion of the APS site drains to the south. Water accumulated in the area encompassed by the eastern half of the storage ring is collected and routed to Wetland $\mathrm{R}$ near the southern APS site boundary. Wetland R also receives drainage from roadways and a parking lot outside the storage ring. The quantity of water provided to Wetland $\mathrm{R}$ has a high degree of fluctuation, depending on rainfall patterns. Water entering Wetland $\mathrm{R}$ may contain some salts and other compounds from roadways and parking areas.

Stormwater from the northwestern portion of the APS site is currently routed to a vegetated collection basin located southeast of the intersection of Kearney and Rock Roads. This basin has minimal storage capacity. The collection basin receives surface runoff from a small parking area and access road, drainage ditches along the east side of Kearney Road and the south side of Rock Road, a parking area near LOM 438, and roof drains from the western portion of the APS ring. The total drainage area of the basin is approximately $614,400 \mathrm{ft}^{2}\left(57,000 \mathrm{~m}^{2}\right)$, about $36 \%$ of which consists of impervious surfaces. The vegetated surfaces permit some stormwater to infiltrate to subsurface soils, slow the movement of surface runoff, and potentially filter out some contaminants originating in parking areas. Vegetation within the basin helps to reduce the velocity of surface water flow through the basin, permitting some additional removal of suspended particles and slight reduction of flow peaks. Surface water flows north out of the basin through a culvert under Rock Road and into a small stream that feeds directly into Wetland 302

Short-lived activation products can be produced in the water circulated in a closed system to cool the accelerator component of the APS. Small amounts of this water may be released to the wastewater treatment system as part of maintenance operations. Oxygen-15 (O-15), the primary activation product in the cooling water, has a very short half-life ( 2 minutes) and decays before maintenance begins. Measurement data at the wastewater treatment plant outfall do not show the existence of O-15 in the effluent (Golchert et al. 2001).

\subsubsection{Groundwater}

Two principal aquifers are used as water supplies in the vicinity of ANL-E and are located at depths of approximately $200 \mathrm{ft}(60 \mathrm{~m})$ and 500 to $1,500 \mathrm{ft}$ (150 to $450 \mathrm{~m})$ below the surface. In northeastern Illinois, the shallow groundwater is within glacial drift units of varying character and extent, and within the underlying Silurian dolomite (Hughes et al. 1966). At the APS, the depth to dolomite is about $100 \mathrm{ft}$ (Killey and Trask 1994). The glacial drift comprises the Wadsworth formation and the underlying Lemont formation (Killey and Trask 1994), both of which are dominated by silty and clayey, low-permeability materials. However, the drift also contains sand, gravel, and silt units that are capable of transmitting water. Because of complex erosional and depositional processes during glaciation, these units vary in thickness, texture, and lateral extent, and their interconnectedness between boreholes is uncertain. A drilling program at the APS site suggests that the uppermost sand unit is at an elevation of about $720 \mathrm{ft}(219 \mathrm{~m})$ 
(Killey and Trask 1994), although thin, minor sand units may be locally present in unsampled areas.

The APS facility does not use or discharge to groundwater. Potential contamination of groundwater by infiltration of contaminants in soil is negligible because of negligible soil contamination. Discussions on soil contamination are provided in Section 4.2.

After 1997, ANL-E began to receive Lake Michigan water originating from the City of Chicago municipal water system. ANL-E now receives all its water from this source, as purchased through the DuPage County Water Commission. Surrounding communities obtain drinking water from the Lake Michigan supply and private wells. A few neighboring homeowners still rely on groundwater wells. Nearby residents who use groundwater are north and west of the APS and upgradient of the facility.

\subsection{AIR QUALITY AND NOISE}

\subsubsection{Meteorology}

The climate of the area is representative of the upper Mississippi Valley as moderated by Lake Michigan. The meteorology of the ANL-E site is monitored at the on-site ANL-E meteorological station, which is located adjacent to the APS site. Meteorological conditions for 2000 are summarized in the ANL-E 2000 Site Environmental Report (Golchert et al. 2001).

The long-term average wind direction varies from west to south, with a significant northeast component. Average annual historical precipitation for ANL-E is 31.98 in. (79.95 cm). Precipitation is due to rain and thunderstorm activity in the spring and summer and sleet and snow in the winter. Severe weather includes the threat of tornadoes in the spring and summer. ANL-E has been struck by tornadoes in the past; damage was minor. The average monthly historical temperature is $47.49^{\circ} \mathrm{F}\left(8.6^{\circ} \mathrm{C}\right)$, with a high average temperature of $71.06^{\circ} \mathrm{F}\left(21.7^{\circ} \mathrm{C}\right)$ in July and a low average temperature of $27^{\circ} \mathrm{F}\left(-4.2^{\circ} \mathrm{C}\right)$ in January.

\subsubsection{Air Quality}

Air emissions at the ANL-E site are discussed in the 2000 Site Environmental Report (Golchert et al. 2001). Table 4.1 compares the emissions from ANL-E and the APS with emissions in the nearest three counties. At the end of 2000, a total of 47 individual air pollution control permits were in place, including 26 permits for radionuclide emission sources. As of December 31, 2000, the APS emission sources subject to permit included three emergency generators (for combustion product emissions) and the APS (for radionuclide emissions). On April 3, 2001, ANL-E received a sitewide Title V Operating Permit covering all regulated air pollutants at the facility. The above mentioned sources are covered under this sitewide permit. 
TABLE 4.1 Emissions from ANL-E and Nearby Counties ${ }^{a}$

\begin{tabular}{lllllll}
\hline & \multicolumn{7}{c}{ Emissions (tons/yr) } \\
\cline { 2 - 7 } \multicolumn{1}{c}{} & \multicolumn{7}{c}{ Source $^{\mathrm{b}}$} & $\mathrm{SO}_{2}$ & $\mathrm{NO}_{\mathrm{x}}$ & $\mathrm{VOCs}$ & $\mathrm{CO}$ & $\mathrm{PM}_{10}$ & $\mathrm{PM}_{2.5}$ \\
\hline & & & & & & \\
Three counties $^{\mathrm{c}}$ & 147,000 & 148,000 & 172,000 & 116,000 & 83,000 & 32,100 \\
ANL-E & 84.3 & 116 & 0.9 & 45.1 & 1.33 & $<1.33$ \\
APS total & 0.349 & 2.14 & 0.069 & 1.18 & 0.080 & $<0.080$ \\
APS facility & 0 & 0.028 & 0 & 0 & 0 & 0 \\
APS emergency generators & 0.349 & 2.12 & 0.069 & 1.18 & 0.080 & $<0.080$ \\
\hline
\end{tabular}

a County emissions are for 2001; ANL-E and APS emissions are for 2000.

b $\mathrm{CO}=$ carbon monoxide; $\mathrm{NO}_{\mathrm{x}}=$ nitrogen oxides; $\mathrm{PM}_{10}=$ particulate matter with an aerodynamic diameter equal to or less than 10 micrometers; $\mathrm{PM}_{2.5}=$ particulate matter with an aerodynamic diameter equal to or less than 2.5 micrometers; $\mathrm{SO}_{2}=$ sulfur dioxide; VOCs $=$ volatile organic compounds.

c ANL-E is in DuPage County near the borders of Cook and Will Counties.

Sources: EPA (2003); Golchert et al. (2001).

ANL-E is in DuPage County, which is within the Metropolitan Chicago Interstate Air Quality Control Region and within the Chicago-Gary-Lake County severe ozone nonattainment area. Table 4.2 compares state ambient quality standards and highest concentrations of criteria pollutants measured near ANL-E in 2001. Illinois ambient standards are the same as the Federal National Ambient Air Quality Standards.

A list of environmental permits issued to ANL-E is provided in Appendix C.

\subsubsection{Noise}

Sources of noise at ANL-E include car and truck traffic and utilities, such as fans, motors, air conditioners, cooling towers, chillers, and transformers. Interstate 55, the Stevenson Expressway, immediately north of the site, and Lemont Road, to the west, are heavily traveled by high-speed traffic, including trucks.

\subsection{LAND USE, RECREATION, AND AESTHETICS}

The APS is part of ANL-E, a DOE energy research and development facility. The ANL-E facility is a campus-like setting, with buildings and facilities interspersed with woodlands, grassland, and wetlands that provide mitigation for impacts to other wetlands on the ANL-E site. ANL-E is surrounded by the Waterfall Glen Forest Preserve of the DuPage County Forest 


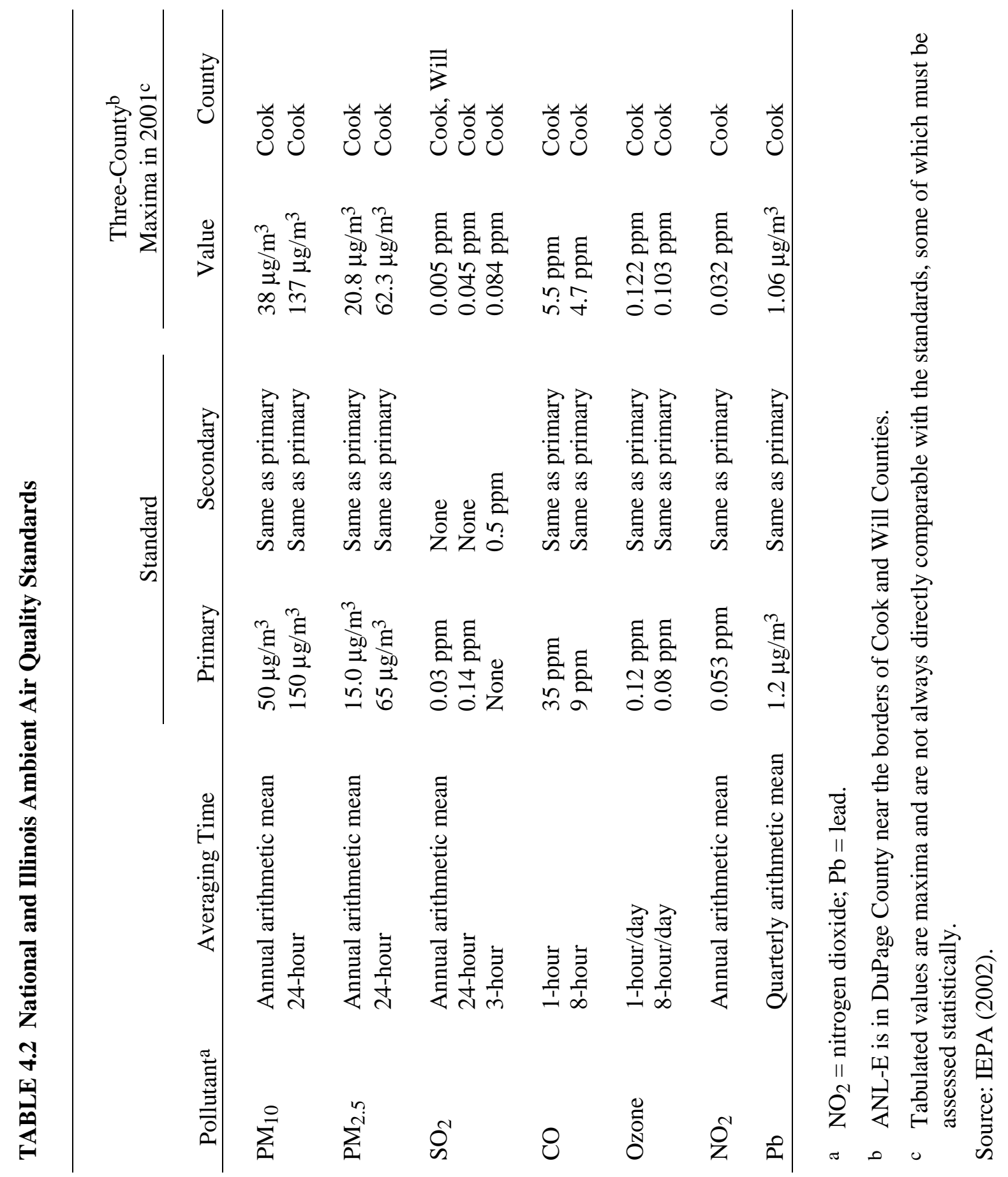


Preserve District. This forest preserve contains trails for hiking, biking, horseback riding, crosscountry navigation sports, and cross-country skiing. Parking facilities are maintained just north of the main entrance of ANL-E. The Argonne Park is a picnic and recreational area in the eastern portion of the ANL-E site that also contains the Argonne Child Development Center, a day care center for site employees.

The APS is located amid a backdrop of woods, grassland, and wetlands, which provide mitigation for impacts to wetlands on the ANL-E site. The multistory main building of the APS is visible from adjacent facilities at ANL-E but is not visible to most nearby residential developments. The APS is visible from higher elevations in the town of Lemont to the south. Other visible structures include the multistory Argonne Guest House, which is located just north of the APS site. Land adjacent to the APS site to the south is part of the Waterfall Glen Forest Preserve; this area can be accessed by road and contains trails and a model airplane field. APS facilities are visible to hikers and bikers traveling through the area and other day users.

\subsection{ECOLOGICAL RESOURCES}

\subsubsection{Terrestrial Biota}

The 1,500-acre (608-ha) ANL-E site includes approximately 850 acres (344 ha) of developed areas (e.g., facilities, roadways, and parking lots) and 650 acres (264 ha) of relatively undisturbed woodlands, old fields, and wetlands. The site is surrounded by the Waterfall Glen Forest Preserve, which contains habitat types similar to the undeveloped habitats present on ANL-E. The 2,240-acre (907-ha) preserve is managed by the Forest Preserve District of DuPage County.

Habitats on the ANL-E site include mature and immature deciduous forest, coniferous forest, open woodland, old field, prairie, wetland (marsh and forested wetland), and open water. Large areas of mowed lawn are present in developed areas of the site. Mowed lawn, deciduous forest, and old field are the most common habitat types, each encompassing about 250 acres (100 ha). The dominant species of deciduous forest communities are various species of oak, primarily white oak, bur oak, red oak, and black oak. Coniferous forest totals about 100 acres (40 ha) and consists of planted jack pine, white pine, and red pine stands. Old-field habitats are dominated by non-native grasses and forbs, including many invasive species, with infrequent occurrences of native prairie grass and forb species. Mowed lawns are maintained in the facility areas, Argonne Park area, and roadsides.

The diverse habitats at ANL-E support a high diversity of wildlife species. Common mammal species include striped skunk, coyote, raccoon, opossum, woodchuck, eastern chipmunk, fox squirrel, muskrat, deer mouse, short-tailed shrew, and white-tailed deer. European fallow deer also occur on the site. American toad, western chorus frog, and green frog are common amphibians, while northern water snake, and eastern garter snake are common reptiles. Common bird species include mallard, Canada goose, mourning dove, blue jay, American crow, 
American robin, European starling, common grackle, common yellowthroat, song sparrow, and northern cardinal.

Terrestrial habitats in the vicinity of the APS facility, bounded by Rock, Kearney, and Bluff Roads, consist primarily of mowed lawns and other landscaped areas. These vegetated areas are predominantly composed of non-native grass and forb species. A vegetated stormwater collection basin is located southeast of the intersection of Kearney and Rock Roads (Figure 4.2). The basin and much of the surrounding area support a herbaceous vegetation cover and are frequently mowed. A number of native species occur within several small areas of the basin.

Several mature trees (shagbark hickory and bur oak) are located south of Rock Road, adjacent to the stormwater collection basin. A periodically mowed area in the southwest corner of the APS site includes a number of native species commonly found in disturbed areas of the ANL-E site. A 4-acre (2-ha) restored prairie community surrounds a constructed wetland (Wetland R) southeast of the APS facility, across Bluff Road (Figure 4.2). Terrestrial vegetation within the APS ring infield consists primarily of mowed grasses. A small percentage of these grasses consist of native species; however, most of the vegetation within the infield consists of non-native species. The APS infield includes a number of stormwater collection areas consisting of interconnected shallow basins and depressions. Surface runoff collected in the basins in the eastern half of the infield is conveyed to Wetland $\mathrm{R}$ by an underground drain line. Some reduction in surface water flow velocities is accomplished by the vegetation cover on the stormwater collection areas.

\subsubsection{Wetlands and Aquatic Biota}

A survey of wetlands on the ANL-E site was conducted in 1993 (Van Lonkhuyzen and LaGory 1994). Thirty-five wetlands, totaling 44.6 acres (18.1 ha), were identified and delineated. Wetland types on the ANL-E site include marshes, forested wetlands, and scrub-shrub wetlands. Marshes are the most common wetland type and are dominated by cattails, grasses, sedges, and rushes. Many wetlands on the ANL-E site occur along streams. Some wetlands have been formed as a result of human or beaver activities. Several high-quality, relatively undisturbed wetlands occur on the ANL-E site; a number of wetlands, however, are relatively disturbed and generally support degraded plant communities with invasive species and low species diversity. Invasive plant species are especially prevalent in disturbed wetlands and form dense colonies in several areas. Disturbance, pollution, alteration of natural hydrologic regimes, and increased sedimentation generally favor the colonization and spread of invasive species.

Wetland R, a 1.8-acre (0.7-ha) wetland (Figure 4.2), was created southeast of the APS ring to mitigate the losses of two small wetlands during initial construction of the APS facility. Hydrologic sources for this wetland include the adjacent surrounding watershed as well as the stormwater collection system within the eastern half of the APS infield area. Large fluctuations in hydrologic inflow periodically occur in Wetland $\mathrm{R}$ following storm events, possibly indicating a high degree of surface water runoff in the infield area. Surface runoff characteristics may be related in part to vegetative cover and a predominance of non-native species. Although 


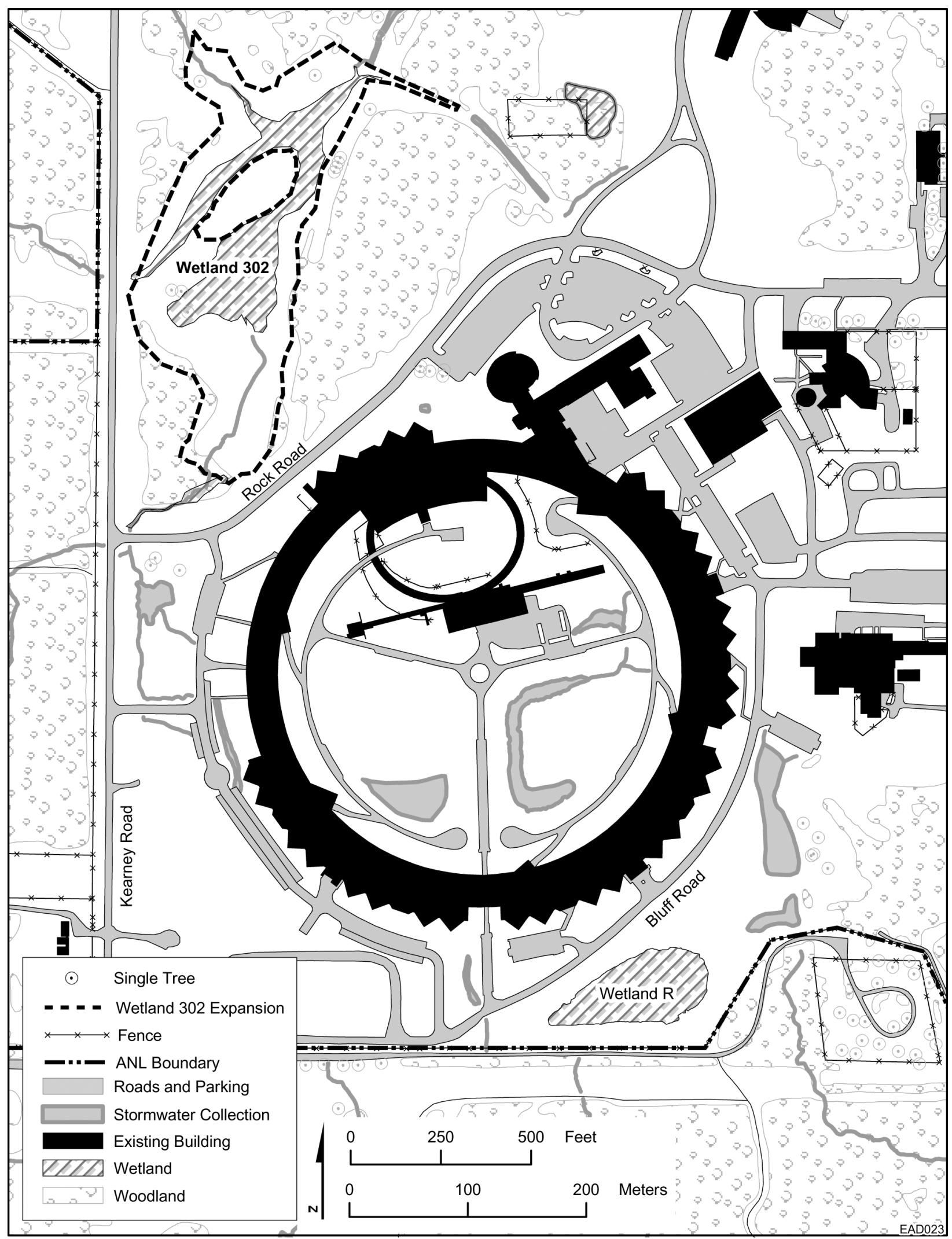

FIGURE 4.2 Wetland Area and Wooded Area at the APS Site 
Wetland R supports a high diversity of native wetland species, invasive species are the dominant plant species, forming dense stands in some areas. The predominance of these species has limited the value of this wetland as mitigation. The invasive species include cattail (two species and a hybrid) and river bulrush, which are native species, as well as reed canary grass and common reed, both non-natives. The invasive species are tolerant of poor water quality and altered hydrologic regimes and may indicate a predominance of surface runoff hydrology in the watershed. Wetland management techniques, including the use of herbicides and prescribed burning, have been used to reduce the occurrence of these species in Wetland R.

At the time the APS facility was constructed, a small wetland, identified as Wetland C (DOE 1990), was located approximately $110 \mathrm{ft}(34 \mathrm{~m})$ southwest of the facility footprint. This wetland, approximately 1.1 acres ( $0.45 \mathrm{ha}$ ) in size, was shallowly inundated in spring or following heavy rains and was supported primarily by groundwater discharge. The vegetation community of Wetland $\mathrm{C}$ was composed entirely of herbaceous species, including many native sedges and forbs. This wetland was avoided during construction of the APS, and any impacts were expected to be temporary (DOE 1990). Following the construction of the APS, the hydrologic regime of Wetland $\mathrm{C}$ became drier, with inundation occurring less frequently and for shorter duration, likely due to changes in groundwater flow. This location now lacks wetland hydrology, and the vegetation community is composed primarily of non-native species, including a number of upland species.

A wetland area (Wetland 302) located immediately northwest of the APS facility, across Rock Road, has been restored for compensatory wetland mitigation at the ANL-E site (Figure 4.2). Under the restoration program, Wetland 302 is expected to increase in size from 3.2 acres (1.3 ha) to a potential maximum of 9 acres ( $4 \mathrm{ha})$. If the wetland restoration is successful, the increased wetland area will provide compensation for the loss of the former Wetland $\mathrm{C}$ and could also provide compensation for potential future wetland impacts on the ANL-E site. Restoration activities included removal of agricultural drain tiles and planting of native species. Surface water inflows to this wetland include the south branch of Freund Brook, an unnamed intermittent stream flowing from the southwest, and a small drainage entering from the northwest. A vegetated stormwater collection area located on the northwest side of the APS facility at the intersection of Kearney and Rock Roads receives surface flow from nearby landscaped areas, parking areas, roads, and roof drains and conveys surface water into the intermittent stream near its entry into the wetland mitigation site.

Wetland 302 restoration goals include an expansion of the wetland area through groundwater recharge and the development of vegetation communities characterized by desirable native plant species. The successful establishment of desired species and the exclusion of invasive species is tied, in part, to watershed characteristics, which include a predominance of native habitats that contribute to a natural hydrologic regime and the high water quality of inflows.

Surface flows from Wetland 302 exit at the northeast and provide the primary inflow to Wetland 303, located immediately downstream. Wetland 303 is approximately 7.5 acres (3.1 ha) in size and consists primarily of marsh communities. The south branch of Freund Brook exits Wetland 302 on the northeast. 
The 100-year floodplain of Freund Brook is located northwest of the APS facility (FEMA 1982), across Rock Road and approximately $250 \mathrm{ft}(76 \mathrm{~m})$ from the building. The floodplain extends upstream, west of Kearney Road, and downstream to the northeast of Wetland 302.

Aquatic habitats on the ANL-E site include streams (primarily Sawmill Creek and the north and south branches of Freund Brook), ditches, and ponds. Fish species occurring on the ANL-E site include goldfish, creek chub, golden shiner, stoneroller, black bullhead, bluegill, green sunfish, orange-spotted sunfish, largemouth bass, and black crappie. Aquatic invertebrates include larvae of numerous insect species such as blackflies, midges, mosquitoes, caddisflies, and dragonflies, as well as crayfish.

\subsubsection{Threatened and Endangered Species}

No federally listed threatened or endangered species are known to occur on the ANL-E site (Tuggle 1996); however, several listed species have been reported from the nearby Waterfall Glen Forest Preserve. The Hine's emerald dragonfly (Somatochlora hineana), federally listed as endangered, occurs in wetlands associated with calcarious seeps from the dolomite aquifer along the Des Plaines River floodplain, about 3,750 ft (1,000 m) south of ANL-E. Suitable habitat for the dragonfly does not occur at ANL-E (DOE 1990). The leafy prairie clover (Dalea foliosa), also federally listed as endangered, is associated with dolomite prairie remnants in the Des Plaines River valley. Two populations of this species have been planted in the Waterfall Glen Forest Preserve. Dolomite prairie habitat does not occur on the ANL-E site. The Indiana bat (Myotis sodalis), federally listed as endangered, may occur in the ANL-E region as indicated by an unconfirmed capture in the Waterfall Glen Forest Preserve (DOE 1990). Trees with exfoliating bark may be used by the Indiana bat as summer roosting sites, particularly those in forested areas near open water. A planted population of the lakeside daisy (Hymenoxys herbacea), federally listed as threatened, is also located in the Waterfall Glen Forest Preserve. Other federally listed species (bald eagle [Haliaeetus leucocephalus], piping plover [Charadrius melodus], and least tern [Sterna antillarum]) could occur in the ANL-E area as extremely rare nonbreeders during migration or in winter.

Several species listed as threatened or endangered by the State of Illinois occur in DuPage County. The black-crowned night heron (Nycticorax nycticorax), state-listed as endangered; Kirtland's snake (Clonophis kirtlandii), listed as threatened; pied-billed grebe (Podilymbus podiceps), listed as threatened; brown creeper (Certhia americana), listed as threatened; and red-shouldered hawk (Buteo lineatus), listed as threatened, have all been observed on the ANL-E site. The black-crowned night heron has been observed at many open water areas at ANL-E, while the pied-billed grebe has been observed at Freund Brook. The redshouldered hawk and brown creeper have been observed in the 600 Area and may utilize most of the wooded areas on-site. Kirtland's snake (Clonophis kirtlandii), listed as threatened, may occur on the ANL-E site. The only observation of a Kirtland's snake at ANL-E occurred in 1989, when one individual was found southwest of the APS, west of Kearney Road. No other state-listed species are known to occur at ANL-E, although the river otter (Lutra canadensis), listed as threatened; osprey (Pandion haliaetus), listed as endangered; shadbush (Amelanchier interior), listed as endangered; slender sandwort (Arenaria patula), listed as threatened; Tuckerman's 
sedge (Carex tuckermanii), listed as endangered; Hill's thistle (Cirsium hillii), listed as threatened; white lady's slipper (Cypripedium candidum), listed as threatened; glade quillwort (Isoetes butleri), listed as endangered; and marsh speedwell (Veronica scutellata), listed as threatened, occur in the vicinity of the ANL-E site. In addition, the Blanding's turtle (Emydoidea blandingii), state-listed as threatened, is known to occur in DuPage County.

No Federal- or state-listed species is known to occur on the APS facility site. Habitats on the site are predominantly disturbed and generally would not provide suitable habitat for listed species. Although wetlands (such as marshy meadows, woodland ponds, and open swamplands) are the preferred habitat for Kirtland's snake, this species may occasionally be found in mowed grassland areas. However, the presence of this species on the APS site would be unlikely because of the availability of abundant preferred habitat elsewhere in the vicinity.

\subsection{CULTURAL RESOURCES}

Cultural resources include archaeological sites and historic structures and features that are protected under the National Historic Preservation Act (NHPA) of 1966, as amended. Cultural resources also include traditional cultural properties that are important to a community's practices and beliefs and are necessary to maintain the community's cultural identity. Cultural resources that meet the eligibility criteria for listing on the National Register of Historic Places (NRHP) are considered "significant" resources and must be taken into consideration during the planning of federal projects. Federal agencies are also required to consider the effects of their actions on sites, areas, and other resources (e.g., plants) that are of religious significance to Native Americans as established under the American Indian Religious Freedom Act. Native American graves and burial grounds are protected by the Native American Graves Protection and Repatriation Act.

\subsubsection{Archaeological Resources}

The entire ANL-E facility has been surveyed for archaeological resources. The surveys have identified 46 archaeological sites, consisting of both prehistoric sites and historic era farmsteads.

Ten archaeological sites were previously identified in the area occupied by the APS (11Du133, 11Du134, 11Du135, 11Du136, 11Du188, 11Du189, 11Du198, 11Du200, 11Du206, and 11Du209). These sites were mitigated through excavation prior to APS construction (Walitschek et al. 1988). All 10 sites have been completely removed. Three additional sites were previously identified near the APS (11Du190, 11Du201, and 11Du202) (Curtis and Berlin 1980). Sites 11Du190 and 11Du202 are historic sites located west of Kearney Road. Site 11Du201 is a site containing both historic and prehistoric material that is located north of Rock Road and east of Kearney Road. 


\subsubsection{Traditional Cultural Properties}

The land around ANL-E, originally held by the Sauk and Fox Tribes, was ceded to the Potawatami, Ottawa, and Chippewa tribes in 1804. In 1816, a treaty was signed that ceded this land to the United States, including land along the Illinois and Des Plaines Rivers (Alvord 1922:449). The remainder of tribal lands in northern Illinois were ceded in 1836 (Tanner 1987:159).

No known traditional cultural properties have been identified within ANL-E.

\subsubsection{Historic Structures}

ANL-E was established in 1946 as the first national laboratory. Over the course of more than 50 years, ANL-E has contributed to our knowledge of nuclear science and technology. A sitewide historic building inventory was completed and received State Historic Preservation Officer (SHPO) concurrence in 2001(Wescott and O'Rourke 2001). This inventory evaluated Cold War era structures and facilities at ANL-E for their historical importance. The APS was not evaluated as part of this inventory because it was constructed after 1989, the end of the Cold War. However, several structures near the APS were identified as eligible for listing on the NRHP, such as the Chicago Pile-5 Reactor/Building 330, the Physics and Metallurgy Hot Laboratory/Building 301, and the Building 314/315/316 Complex.

\subsection{SOCIOECONOMICS}

The ANL-E region of interest, consisting of the area within a 50-mi $(80-\mathrm{km})$ radius of the site, is located in a culturally and economically diverse urban area of more than 8.7 million residents. Neighboring communities include areas that are suburban, commercial, and industrial in character, with businesses in services, manufacturing, transportation, energy, and research and development. Communities are well served by community services, including police and fire, education (preschool through graduate level), and health services. Housing opportunities for low-, middle-, and high-income families exist in the immediate vicinity of ANL-E. Employment centers include the City of Chicago as well as manufacturing, business, and corporate centers in nearby areas.

ANL-E employs about 3,500 full-time equivalents (FTEs). In addition, more than 4,600 visiting researchers use ANL-E research facilities each year. These visitors seek lodging and other services at the commercially operated Argonne Guest House or in the nearby area. 


\subsection{HUMAN HEALTH}

\subsubsection{Radiological Environment}

Potential radiological effects presented in this section are expressed in terms of mrem for radiation doses, which can be converted to potential latent cancer risks using the dose-torisk conversion factors listed in Table 4.3. Lifetime cancer risk can be estimated by multiplying cancer risk estimated for one-year exposure by the duration of exposure in years and is interpreted as the probability of contracting a cancer during a lifetime as a result of the radiation exposure. For the general public, the dose-to-risk conversion factor is greater than that for radiation workers because it includes consideration of radiosensitive populations such as infants and young children. According to the National Council on Radiation Protection and Measurements (NCRP 1987), the average dose to a member of the general public in the United States resulting from natural background radiation and medical sources is $360 \mathrm{mrem} / \mathrm{yr}$, which is equivalent to a cancer risk of $1.8 \times 10^{-4} / \mathrm{yr}$. (1.8 chances in 10,000)

At the APS, X-rays are generated by bending the electron beam; X-rays generated in this manner are called synchrotron radiation. The synchrotron radiation X-rays are photons, or packets of light, and represent a potential radiation hazard during APS operations. Lead shielding is used to protect people working near the photon beams from radiation.

The high-energy electrons inside the storage ring cause another type of radiation hazard. When one of these high-energy electrons hits atoms in air, water, or storage ring components, the atom can emit high-energy photons moving in the direction of the electron. When the highenergy photons hit other atoms, they can knock neutrons out of those atoms. These neutrons can be absorbed by neighboring atoms, making the atoms unstable or radioactive. This process is called activation. APS components, air, and water can become activated and remain radioactive for some time after APS operations stop.

Normal Conditions. APS facility operations can expose an individual living or working in its vicinity to external and internal radiation through various pathways. Direct external radiation can be incurred when an individual is close to activated APS components or to APS beamlines. Exposure to external and internal radiation can occur when an individual is exposed to and inhales air activation products released by the APS. Potential receptors discussed in this section include APS workers (that is workers having access to most areas of the APS), beamline users (scientists using the APS and having access to experimental areas), on-site workers (other workers at the ANL-E site), and the off-site public.

According to Moe (1991), at the closest approach location, $1.3 \mathrm{~m}$ (4.3 ft) from the APS storage ring, the external dose rate was estimated to be about $0.05 \mathrm{mrem} / \mathrm{h}$. Assuming an APS worker (the maximally exposed individual, MEI) spends 2,000 h/yr working at this location, the 
radiation dose he receives would be $100 \mathrm{mrem} / \mathrm{yr}$, which is a small fraction of the dose limit of $5,000 \mathrm{mrem} / \mathrm{yr}$ set to protect radiation workers (10 CFR 835).

Beamline users would be exposed to radiation in the module experimental areas. The external radiation dose in module experimental areas was conservatively estimated to be $5.8 \mathrm{mrem} / \mathrm{yr}$ (Moe 1991) for the MEI of the beamline users, assuming an exposure duration of $2,000 \mathrm{~h} / \mathrm{yr}$ at a distance of $20 \mathrm{~m}$ (66 ft) from the storage ring. In reality, no positive exposure was found among the APS workers and beamline users in 2000 and 2001, according to the dosimetry data (Dolecek 2002). A total of about 1,800 dosimetry badges were issued each year.

At the nearest site boundary, assumed to be $140 \mathrm{~m}(459 \mathrm{ft})$ from the electron orbit, the annual external radiation dose was estimated to be $6.25 \mathrm{mrem} / \mathrm{yr}$ ( $2 \mathrm{mrem} / \mathrm{yr}$ from direct radiation and $4.25 \mathrm{mrem} / \mathrm{yr}$ from skyshine) for an 8,000-hour operation (Moe 1991). Therefore, for an on-site worker within the same distance from the electron orbit, the maximum external radiation dose would be $1.56 \mathrm{mrem} / \mathrm{yr}$, assuming an exposure duration of 2,000 hours per year and no shielding protection. According to the environmental monitoring data for penetrating gamma radiation in 2001 (Golchert and Kolzow 2002), the average background level in the local area was about $103( \pm 20) \mathrm{mrem} / \mathrm{yr}$; radiation levels measured at two locations at the ANL-E fence line about $350 \mathrm{~m}$ from the electron orbit were $122( \pm 23) \mathrm{mrem} / \mathrm{yr}$ and $116( \pm 16) \mathrm{mrem} / \mathrm{yr}$. In 2000 (Golchert et al. 2001), the average background level was measured to be 99 ( \pm 20 ) $\mathrm{mrem} / \mathrm{yr}$; levels measured at the two fence line locations were $101( \pm 4)$ and $102( \pm 6) \mathrm{mrem} / \mathrm{yr}$. Radiation levels at these two fence line locations were impacted not only by APS operations but also by the operations of other ANL-E facilities. Measurements at these two fence line locations are not statistically different from the background level. Therefore, potential external radiation exposures received by the off-site public from the APS operations are expected to be small.

The APS operations can cause air activation inside the accelerator shielding enclosure, resulting in airborne emission of radionuclides. Primary airborne activation products are C-11, $\mathrm{N}-13$, and $\mathrm{O}-15$, of which $\mathrm{N}-13$ makes up about $90 \%$ of the radionuclide emissions. The concentrations of these radionuclides are below the detection limit of the APS stack monitor. It is estimated that a total of $7.38 \mathrm{Ci}(0.1 \mathrm{Ci}$ of $\mathrm{C}-11,6.56 \mathrm{Ci}$ of $\mathrm{N}-13$, and $0.72 \mathrm{Ci}$ of $\mathrm{O}-15)$ (Golchert and Kolzow 2002) were released from the APS facility in 2001. Using these estimates and CAP88-PC (a U.S. Environmental Protection Agency [EPA] air dispersion model), the maximum radiation dose to a hypothetical individual living at the fence line (south-southeast $1,312 \mathrm{ft}[400 \mathrm{~m}]$ from the emission stack) was estimated to be $0.0043 \mathrm{mrem} / \mathrm{yr}$; the radiation dose to the nearest off-site resident (west-southwest 2,625 ft [800 m] from the emission stack) was $3.2 \times 10^{-4} \mathrm{mrem} / \mathrm{yr}$ (Golchert and Kolzow 2002). These estimated radiation doses are extremely small compared with the radiation dose limit of $10 \mathrm{mrem} / \mathrm{yr}$ set for airborne emissions (Title 40, Part 61, of the Code of Federal Regulations [40 CFR 61]). In the same year, a total of about 1,466 $\mathrm{Ci}$ of radionuclides were released by the entire ANL-E operations. Assuming the $\mathrm{CP}-5$ reactor is the central emission point for the ANL-E site and radiation doses estimated by CAP88-PC for each individual release were combined, then the highest perimeter dose would be $0.38 \mathrm{mrem} / \mathrm{yr}$ in the east direction (Golchert and Kolzow 2002). The maximum perimeter dose resulting from the APS operations was $0.11 \%$ of that from the entire ANL-E operations. 
Short-lived activation products (primarily O-15) can be produced in the water circulated in a closed system to cool the accelerator component of the APS; however, the production rate in water was estimated to be at least an order of magnitude lower than that in air (Swanson 1979). The blowdown water was discharged to the on-site wastewater system, which was discharged off-site after treatment. Oxygen-15, the primary activation product in the cooling water, has a very short half-life ( 2 minutes) and would decay before entering the treatment system. Therefore, potential radiation exposures resulting from the discharge of $\mathrm{O}-15$ in the cooling water are not possible. Other activation products in the cooling water generated by the APS operations are C-11, tritium (H-3), N-13, and beryllium-7 (Be-7). However, according to the estimates made by Moe (1991), the production rates of these isotopes $\left(<4 \times 10^{-5} \mathrm{Ci}\right)$ are small fractions of the production rate of $\mathrm{O}-15$, and the resulting on-site and off-site doses are insignificant.

Table 4.4 summarizes the potential radiation exposures of various receptors from APS operations. The radiation exposures are all well below the dose limit of $100 \mathrm{mrem} / \mathrm{yr}$ set to protect the general public from the DOE operation, or 5,000 mrem/yr set to protect radiation workers (10 CFR 835).

Off-Normal Conditions. Radiation exposures greater than those discussed under normal conditions would occur if the electron beam is lost during the APS operations. However, the chance for such an accident to occur is extremely small because of the implementation of the Access Control and Interlock System (ACIS), an engineering safety system for integrating access control and monitoring devices for the accelerator systems. The ACIS provides protection by ensuring that no one can occupy or enter an area where accelerator beam radiation may be

\section{TABLE 4.4 Maximum Radiation Doses to Various Receptors from the APS Operations}

\begin{tabular}{|c|c|c|c|}
\hline \multirow[b]{2}{*}{ Receptor } & \multirow[b]{2}{*}{ Radiation Source } & \multicolumn{2}{|c|}{$\begin{array}{c}\text { Dose to Individual } \\
(\mathrm{mrem} / \mathrm{yr})\end{array}$} \\
\hline & & Estimated & Measured \\
\hline APS workers & Direct external radiation & 100 & No positive result \\
\hline Beamline users & Direct external radiation & 5.8 & No positive result \\
\hline On-site workers & Direct external radiation & 1.6 & $\mathrm{NA}^{\mathrm{c}}$ \\
\hline \multirow[t]{3}{*}{ Off-site general public ${ }^{a}$} & Direct external radiation & $<6.5$ & Within background level \\
\hline & Airborne emission & 0.0043 & $\mathrm{NA}^{\mathrm{c}}$ \\
\hline & Waterborne emission & $\sim 0$ & $\mathrm{NA}^{\mathrm{c}}$ \\
\hline Member of public or worker & $\begin{array}{l}\text { Natural background radiation } \\
\text { and medical sources }\end{array}$ & $360^{\mathrm{b}}$ & $\mathrm{NA}^{\mathrm{c}}$ \\
\hline
\end{tabular}

a The MEI of the off-site public was assumed to reside at the fence line that would yield the largest dose. An average person would receive a radiation dose much less than the MEI dose.

b Average dose to a member of the U.S. population as estimated in Report No. 93 of the National Council on Radiation Protection and Measurements (NCRP 1987).

c Not available. 
present. It is designed to turn off the source of radiation when there is a possibility of someone being exposed. Furthermore, the potential consequences of beam losses were taken into consideration in radiation shielding design, and local shielding was added to the accelerator components where analyses showed significant radiation exposures could occur.

Among the scenarios analyzed involving beam losses at various APS components, the maximum credible incident (MCI) is based upon a scenario in which the electron beam is lost at the highest elevation in the rising section of the LEUTL line going from the synchrotron to the mezzanine directly above the region of the beam loss (see Figure 4.3 for the location of the

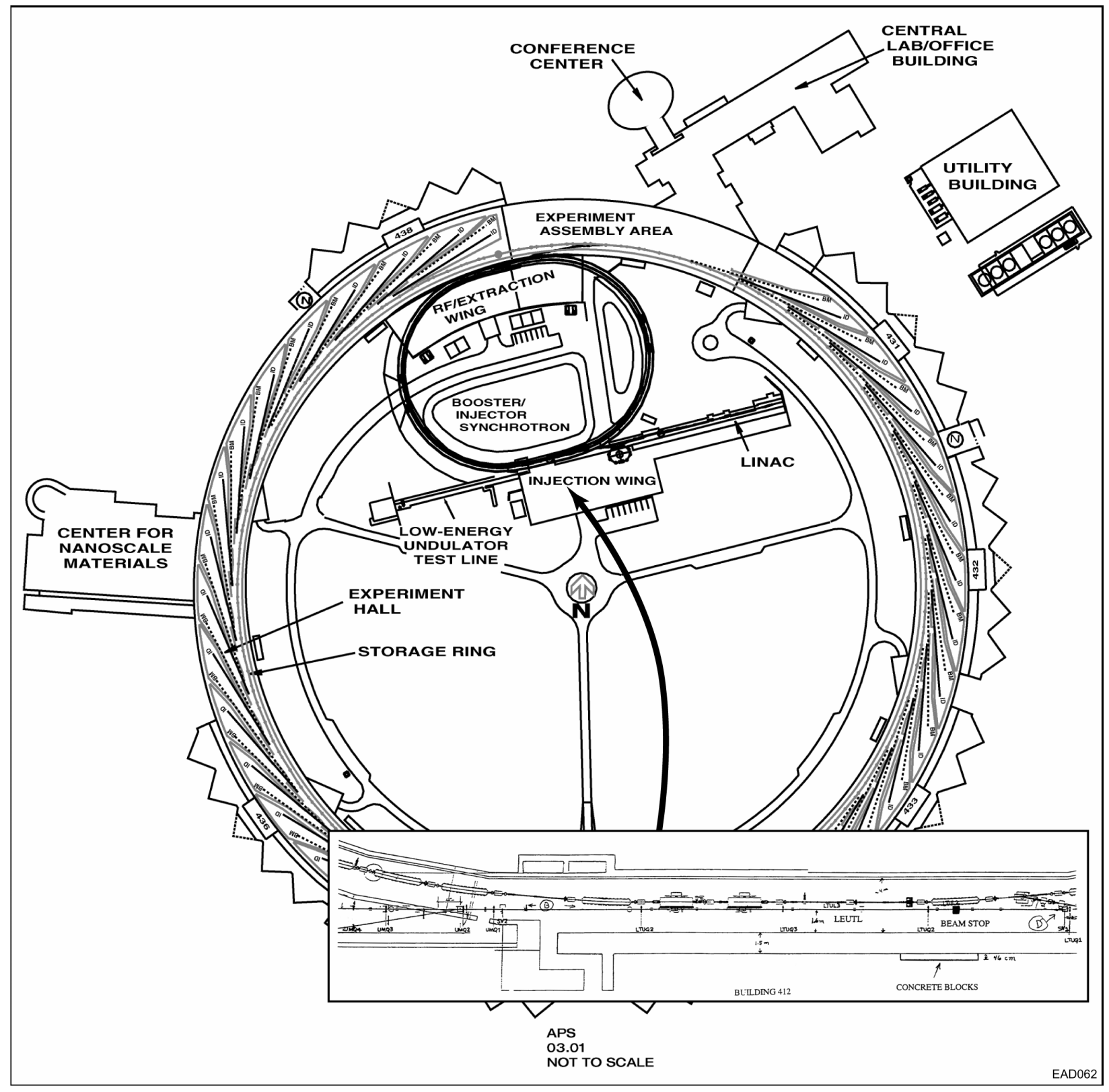

FIGURE 4.3 Location of the Maximum Credible Incident 
incident) (Moe 1998). According to the analysis for the MCI, in which an APS worker was assumed to stand at a distance of $7.9 \mathrm{ft}(2.4 \mathrm{~m})$ from the loss point through the $3-\mathrm{ft}(1-\mathrm{m})$ concrete floor of the mezzanine, the estimated dose rate is $13.1 \mathrm{rem} / \mathrm{h}$. At the concrete floor of the mezzanine, a neutron-gamma radiation monitor is located that is interlocked to the beam. When the radiation level at the mezzanine, close to the loss point, exceeds the set level (10 $\mathrm{mrem} / \mathrm{h}$ for photons and $3 \mathrm{mrem} / \mathrm{h}$ for neutrons), the operation would be turned off, and the beam would trip in just a few microseconds. Assuming this condition persists as long as a minute, the total dose received by the APS worker closest to the loss point would be $218 \mathrm{mrem}$. At a distance of $460 \mathrm{ft}(140 \mathrm{~m})$, the dose to an on-site worker would be about $0.066 \mathrm{mrem}$. The dose to an off-site individual would be less than 0.066 mrem because of a greater exposure distance. Realistically, the radiation exposures would be much smaller than the estimated values because the incident would last much shorter than one minute. On the basis of the calculation results, it is concluded that no significant on-site or off-site impact is expected from a radiation incident at the APS.

\subsubsection{Nonradiological Environment}

Nonradiological contaminants resulting from APS operations come from experimental sources that may include trace amounts of organic solvents, toxic proteins, microbiological products, compounds containing heavy metals, and small amounts of carcinogens. ANL-E uses thousands of chemicals in conducting research in physical, biomedical, chemical, materials, and environmental sciences. These chemicals are tracked from purchase to disposal through the ANL-E Chemical Management System (CMS). The CMS process facilitates compliance with environmental, safety, and health requirements. Reports generated through the CMS identify chemicals that are toxic (including carcinogens) and provide data for completing ANL-E's Toxic Release Inventory (TRI) and Superfund Amendments and Reauthorization Act (SARA) Title III reports.

Nonradiological hazardous contaminants generated at ANL-E, including those generated at APS, are managed in accordance with the ANL-E Plant and Facilities Services (PFS) Waste Management Operations (WMO) Operating Procedures Manual (see Section 4.10.) Nonradiological biological or medical contaminants are managed in accordance with the ANL-E Environment, Safety, and Health (ESH) Manual. Policies contained in that manual require adequate control of exposure potentials (through either engineering or administrative controls, or both) before experimental activities are allowed to commence. Consequently, no potential human exposure to nonradiological hazardous or biological contaminants is expected to occur from APS operations.

A minute amount of nonradiological contaminants is released to laboratory sinks at the APS during rinsing and cleaning activities and is discharged to the ANL-E wastewater treatment plants where it is combined with wastewater from other ANL-E facilities. The wastewater is treated, processed, and discharged to Sawmill Creek through the ANL-E National Pollutant Discharge Elimination System (NPDES) Outfall 001. Wastewater discharges are sampled and analyzed according to requirements in the NPDES permit. In 2001, no exceedance of the regulatory limits for 5-day biological oxygen demand (BOD5), mercury, and chemical oxygen 
demand (COD) occurred, and very small amounts of a few contaminants in concentrations similar to those in treated drinking water were found to be present (Golchert and Kolzow 2002). Because the nonradiological contaminants from APS operations constitute a small fraction of ANL-E wastewater contaminants that are received and treated to NPDES permit limitations before discharge, human exposure to APS contaminants is not expected to occur.

\subsection{WASTE MANAGEMENT}

Research and maintenance activities at the APS result in the generation of small volumes of a variety of wastes. Hazardous wastes generated at the APS are collected in specified waste containers, documented, packaged according to ANL-E waste handling procedures, and initially accumulated at or near the point of generation. Hazardous wastes are then picked up by trained ANL-E WMO personnel. Table 4.5 compares the typical annual volumes of wastes by category that are generated at the APS to the volumes of those waste categories generated by all ANL-E operations. All hazardous waste generated at ANL-E (including universal waste [see Table 4.5]) is delivered by licensed carriers to properly permitted commercial treatment or disposal facilities. All low-level radioactive waste (LLW) generated at ANL-E is delivered by licensed carriers to DOE's disposal facility in Richland, Washington. Other types of waste generated at ANL-E that are not generated at the APS, such as transuranic waste, are not addressed in this EA.

ANL-E holds an Illinois Environmental Protection Agency (IEPA) Resource Conservation and Recovery Act (RCRA) Part B Permit (IL0438020002) that allows ANL-E to manage hazardous waste at several designated container storage areas, one tank storage unit, and several treatment units before the waste is shipped off-site to properly RCRA-permitted treatment, storage, and disposal facilities.

General refuse (nonhazardous solid waste) is discarded to dumpsters staged at ANL-E buildings. To avoid improper disposal of chemical or hazardous wastes, procedures have been established to guide ANL-E personnel on what wastes can be placed in dumpsters. Wastes placed in dumpsters are collected by a commercial waste hauler and transported to the hauler's processing facility where recyclable materials are removed. The remaining waste is transported for disposal to an IEPA-permitted sanitary landfill. Construction and demolition waste is managed in roll-off containers which, when full, are transported by commercial haulers to processing facilities where recyclable materials are removed. Remaining materials are delivered to an IEPA-permitted landfill for disposal.

Wastewater is generated by a number of activities at the APS and consists of sanitary wastewater (from restrooms, cafeteria sinks and sinks in certain buildings and laboratories), laboratory wastewater (from laboratory sinks and floor drains in most buildings), de-ionized and purified water for laboratories and accelerator component cooling, and stormwater. Cooling water and cooling tower blowdown waters are discharged into the ANL-E laboratory wastewater treatment system. 
TABLE 4.5 Hazardous and Radiological Waste Generated Annually by ANL-E and the APS ${ }^{a}$

\begin{tabular}{lcc}
\hline \multicolumn{1}{c}{ Waste Category } & $\begin{array}{c}\text { ANL-E Quantity } \\
\text { (gal) }\end{array}$ & $\begin{array}{c}\text { APS Quantity } \\
\text { (gal) }\end{array}$ \\
\hline & $10,048^{\mathrm{d}}$ & $511^{\mathrm{e}}$ \\
RCRA hazardous waste & $13,672^{\mathrm{d}}$ & $40^{\mathrm{e}}$ \\
HSWA universal hazardous waste & $31,933^{\mathrm{h}}$ & $5^{\mathrm{e}}$ \\
Low-level radioactive wasteg & 321.2 million & 56.8 million \\
Wastewater &
\end{tabular}

a Both solid and liquid wastes were generated. For RCRA reporting, all waste totals are converted to gallons.

b Quantities represent wastes resulting from operations at the following APS divisions: Accelerator Systems Division (ASD), Experimental Facilities Division (XFD), APS User Program Division (UPD), and APS. Wastes related to infrastructure maintenance at BioCARS are also represented in these totals. Pursuant to APS policy, wastes resulting from experiments by external collaborators are returned to the home institutions of those collaborators. The data represent wastes delivered to WMO over the period September 1, 2001, through August 30, 2002.

c RCRA hazardous wastes are defined in 40 CFR 261. Illinois Environmental Protection Agency (IEPA) definitions are equivalent to the federal definitions.

d ANL-E Site Environmental Report, 2001, Section 2.3; see Table 2.7 for hazardous waste generated, treated, disposed of, or recycled in calendar year 2001; see Table 2.8 for mixed waste generated, treated, stored, and disposed of in calendar year 2001 (Golchert and Kolzow 2002).

e Data derived from WMO operating data (McNamee 2003a).

f Hazardous and Solid Waste Amendments of 1984 (HSWA) universal wastes include such items as spent fluorescent bulbs, some pesticides, spent lead acid batteries, and instruments and equipment containing elemental mercury. Universal wastes are defined in 40 CFR 273; IEPA definitions are equivalent to the federal definitions.

g Low-level radioactive waste (LLW) is defined by the U.S. Nuclear Regulatory Commission (NRC) regulation as radioactive waste that (1) is not high-level radioactive waste, spent nuclear fuel, transuranic waste (TRUW), or by-product material as defined in Section 11(e)(2) of the Atomic Energy Act (AEA) of 1954, and (2) is classified by the NRC as LLW.

h Data provided by WMO (McNamee 2003b). 
Wastewater is treated at the APS in two independent treatment systems, the sanitary system and the laboratory system. The sanitary wastewater collection and treatment system collects wastewater from sanitation facilities, the cafeteria, office buildings, and other portions of the site that do not contain radioactive or hazardous materials. This wastewater is treated in a biological wastewater treatment system consisting of primary clarifiers, trickling filters, final clarifiers, and slow sand filters.

Wastewater discharge at ANL-E is permitted by NPDES Permit No. IL 0034592. Under the provisions of this permit, treated sanitary wastewater is combined with treated laboratory wastewater and discharged through Outfall 001 to Sawmill Creek. The permit also addresses 39 other discharge points for industrial wastewaters (including, e.g., cooling water and cooling tower blowdown water) and stormwater that can be discharged without treatment but are required to be monitored by ANL-E. These additional discharge points hydraulically communicate with Sawmill Creek or with the Des Plaines River. The permit was renewed in 1994 (effective date, October 30, 1994), was modified in 1995 (effective date August 24, 1995), and was scheduled to expire on July 1, 1999. An application to renew the existing permit was submitted to the IEPA on December 28, 1998, allowing ANL-E to continue to operate under the provisions of the existing permit until the IEPA issues a replacement permit. A proposed renewal permit was issued for public comment in December 2002 and is expected to be issued in 2003. The volumes of wastewaters discharged at ANL-E in 2001 were 1.4 million L/day (0.38 million gal/day) of sanitary wastewater and 1.9 million L/day ( 0.50 million gal/day) of laboratory process wastewater.

The BSL-2 experiments at the APS generate small amounts of biological waste, less than $1 \mathrm{~kg}$ per year at the current usage of the facility. This waste is disinfected and then disposed of according to established ANL-E protocols.

A list of waste management permits issued to ANL-E is provided in Appendix C.

\subsection{TRANSPORTATION}

The ANL-E area is served by air, rail, and highway transportation systems. In addition, bulk materials are shipped near the ANL-E site along the Ship and Sanitary Canal between the Illinois River and Lake Michigan.

Visitors to the APS site arrive by car. ANL-E is normally accessed on the east by Northgate Road from Cass Avenue and on the west by Westgate Road from Lemont Road. Both access roads are two-lane, hard-surface roadways. Cass Avenue and Lemont Road both have full interchanges with Interstate 55, the Stevenson Expressway, less than one mile north of the site. Traffic entering or leaving ANL-E by Westgate Road is controlled by a traffic light, while traffic leaving ANL-E by either Northgate Road or Eastgate Road is controlled by stop signs. Access to the APS site within ANL-E is by two-lane, hard-surface road on the north, east, and west sides of the site, and the facility is surrounded by a hard-surface access road with parking lots at even intervals around the ring. 


\subsection{UTILITIES AND SERVICES}

Electrical service to ANL-E is provided by Exelon, formerly known as Commonwealth Edison. ANL-E is a member of the ComEd (Exelon) energy cooperative, which is a voluntary agreement to curtail energy use during periods of peak energy demand. APS currently consumes approximately $25 \mathrm{MW}$ of power per year, which is equal to the annual power consumption of approximately 225,000 residential customers. Since the 1990 APS EA was published, purchase of Lake Michigan source water from the DuPage County Water Commission has been implemented as an alternative to reliance upon on-site wells and canal water. ANL-E also has an on-site Central Heating Plant, a boiler facility for producing heat and steam for the site.

\subsection{ENVIRONMENTAL JUSTICE}

On February 11, 1994, the President of the United States issued Executive Order 12898, "Federal Actions to Address Environmental Justice in Minority and Low-Income Populations." This Executive Order mandates that Federal agencies incorporate environmental justice considerations as part of their missions. It directs federal agencies to address, as appropriate, disproportionately high and adverse human health or environmental effects of their actions, programs, or policies on minority and low-income populations. The Executive Order's accompanying cover memo specifically mentions the NEPA, providing the opportunity to incorporate environmental justice as part of the NEPA process.

Approximately 8.7 million people live within census tracts located within a 50-mi $(80-\mathrm{km})$ radius of ANL-E, and approximately 183,000 people live within census tracts located within $5 \mathrm{mi}(8 \mathrm{~km})$ of ANL-E (Table 4.6). On the basis of 2000 census data, $51 \%$ of the $50-\mathrm{mi}$ $(80-\mathrm{km})$ population and $24.5 \%$ of the $5-\mathrm{mi}(8-\mathrm{km})$ population are comprised of minorities, as compared with the state averages of $32.2 \%$ for Illinois, $14.2 \%$ for Indiana, and a national average of $30.9 \%$ (Figure 4.4). On the basis of 1990 census data (2000 data are not yet available), 10.7\% of the $50-\mathrm{mi}(80-\mathrm{km})$ population and $2.4 \%$ of the $5-\mathrm{mi}(8-\mathrm{km})$ population are low-income, as compared with the Illinois average of $11.3 \%$, the Indiana average of $9.9 \%$, and the national average of $13.3 \%$ (Figure 4.5). Table 4.6 summarizes the distribution of minority and lowincome populations in the area surrounding ANL-E. 
TABLE 4.6 Summary of the Distribution of Minority and Low-Income Populations Surrounding ANL-E

\begin{tabular}{lll}
\hline Radial Distance around ANL-E & $50-\mathrm{mi}$ & $5-\mathrm{mi}$ \\
\hline
\end{tabular}

Population and Minority Population Statistics (2000) ${ }^{a}$

Total population

Minority population

Native Americans or Alaska Natives

African Americans

Hispanic origin

Asians or Pacific Islanders and other race categories

Percent of minority populations

\section{Low-Income Population Statistics (1990) ${ }^{a}$}

Total population

$7,839,245 \quad 171,691$

Population below poverty line

$835,673 \quad 4,098$

Percent low-income populations
$8,691,957 \quad 183,256$

$4,252,327 \quad 41,861$

$23,026 \quad 259$

$1,686,284 \quad 10,427$

$1,462,388 \quad 12,277$

$1,080,629 \quad 18,898$

$51 \% \quad 24.5 \%$

a Based on information available for whole census tracts that fall within 50-mi and a 5-mi radii of the center of the APS facility at ANL-E; income data are not yet available for the 2000 census. 


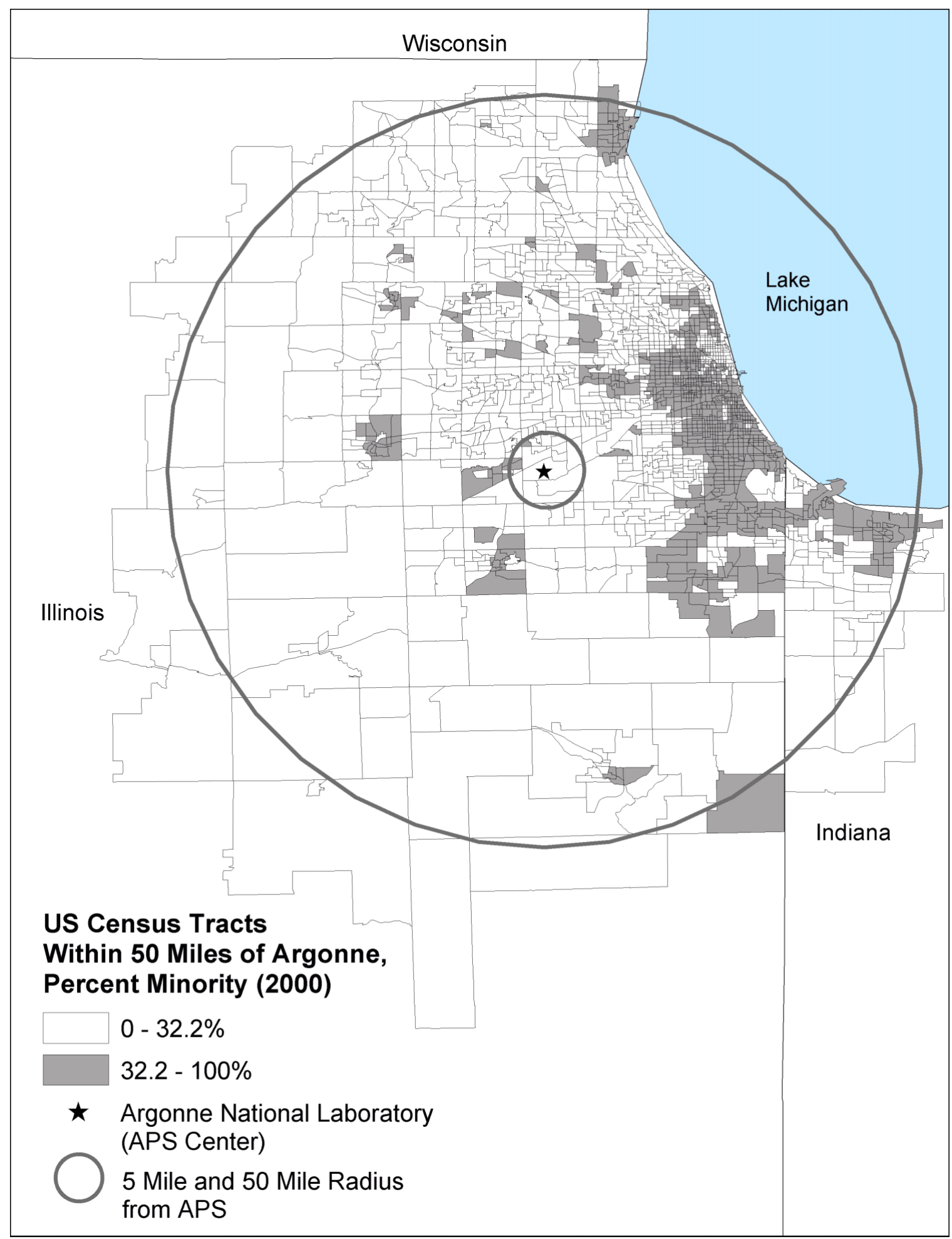

FIGURE 4.4 Minority Composition of Populations within 5 and 50 Miles of ANL-E, Based on 2000 U.S. Census Data 


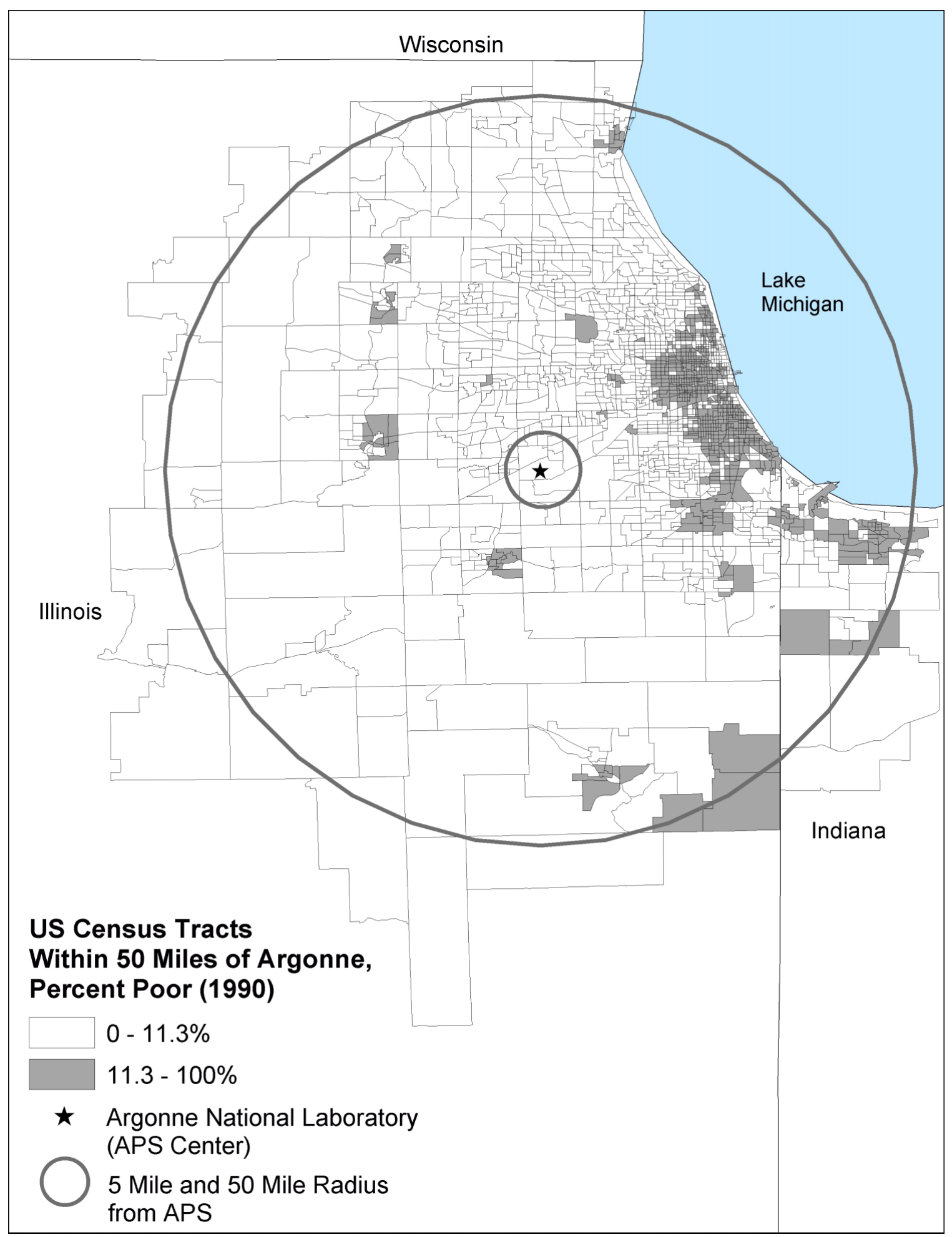

FIGURE 4.5 Income Composition of Populations within 5 and 50 Miles of ANL-E, Based on 1990 U.S. Census Data 


\section{ENVIRONMENTAL CONSEQUENCES OF THE PROPOSED ACTION AND THE NO-ACTION ALTERNATIVE}

This section describes the environmental consequences of the Proposed Action and the No-Action Alternative, as well as the cumulative impacts of the Proposed Action when added to other past, present, and future actions. The Proposed Action includes continuing and enhanced operations of the APS facilities, including construction and operation of new facilities. In each topical area, the impacts of continuing operation are discussed first, followed by the impacts of constructing and operating new facilities. Where appropriate, the potential impacts of BSL-3 research at the APS are also addressed.

Where the impacts of APS operations have changed from the conclusions reached in the 1990 EA for constructions and operations (DOE 1990), these changes are identified. In addition, where appropriate, the wetlands management EA (DOE 2001) is referenced, since wetlands adjacent to the APS facility were included in that document. The environmental remediation EA, prepared for ANL-E in 1997, did not address APS site areas, since no RCRA Solid Waste Management Units (SWMUs) are located in the APS area.

\subsection{EFFECTS OF THE PROPOSED ACTION}

\subsubsection{Soils}

As discussed in Section 4.2, soil activation and contamination are negligible under the current APS operations. The proposed action would not involve changes in the design and operation of the APS primary components (LINAC, LEUTL, synchrotron, and storage ring); therefore, conclusions from Section 4.2 still hold under the proposed action.

Soil erosion at the APS site during continued operations would remain low, as under current conditions (Section 4.2) because the vegetation cover would continue to be maintained. Construction of the CNM facility and parking area (Figure 3.2) would disturb soils on the western side of the APS ring. Construction of the CNM and parking area, beginning as early as 2003, would disturb between 2 and 4 acres ( 0.8 and 2 ha) of land. Most of this area of the APS site has been previously disturbed by construction of the APS ring and a road and parking lot. None of this area is classified as wetland or as a SWMU as defined by RCRA.

During construction of the CNM facility, ANL-E-approved construction practices, such as use of sediment fences, compaction, contouring, and sediment retention basins, would limit potential erosion and runoff. As described in Section 5.1.2, proposed mitigation for stormwater management from the CNM area includes creating a collection basin north of the new facility.

After construction of the CNM facility and parking area, landscaping and revegetation of disturbed soils would retard runoff and control erosion. The sediment load in stormwater runoff 
would be reduced by routing the runoff through a collection basin. No adverse impacts to soils would be expected as a result of implementing the proposed action.

\subsubsection{Water Resources}

\subsubsection{Surface Water: Continued Operations}

Potential surface water impacts at the APS site would continue to be associated only with stormwater discharges. The APS facility sanitary and laboratory wastewaters would continue to be separately collected, treated, and discharged by the ANL-E sanitary wastewater treatment plant and the ANL-E LWTP.

Continued operation of the APS facility as currently configured would continue to include control of stormwater throughout the APS site as described in Section 4.3.1. Under continued operations, attenuation of flow peaks and fluctuations in stormwater flows from the APS site, including flows to Wetland 302, would not be changed. Implementation of vegetation management and placement of flow-control grates for APS infield drainage would improve attenuation of flows into Wetland R. Concentrations of road salt and other materials in flows from roadways and parking lots following snowmelt and rain events would be reduced to a level that would protect the wetland through implementation of a sitewide wetland management plan.

As under current conditions, small amounts of cooling water containing short-lived activation products may be released to the wastewater treatment system as part of maintenance operations. Analysis of outfall effluent would be expected to continue to not detect the presence of O-15, the primary activation product. Thus, no radiation exposures are expected to result from the discharge of the cooling water.

\subsubsection{Surface Water: Enhanced Operations}

Adherence to the Stormwater Pollution Prevention Plan (SPPP), prepared prior to construction, would result in the minimization of impacts to surface water quality from construction of the CNM facility. During the construction, surface water quality impacts would be mitigated by implementation of sediment and erosion control measures (Section 3.1.3). The water quality of stormwater flows into the receiving stream to the north would be protected, and downstream impacts from sedimentation would be avoided.

During operations, stormwater flows would be routed as described in Figure 5.1. During operations of the CNM facility, flows in runoff from all existing and new roof drains would be attenuated by a new collection basin of $10,500 \mathrm{ft}^{3}\left(297 \mathrm{~m}^{3}\right)$ capacity prior to flow to the north. This control would reduce fluctuation in flows and filter and degrade some contaminants. Under the proposed action, the first 3,033 $\mathrm{ft}^{3}\left(86 \mathrm{~m}^{3}\right)$ of runoff from the new APS parking lot would be collected and pumped to the south to a bioswale. Water from this location would drain to the 


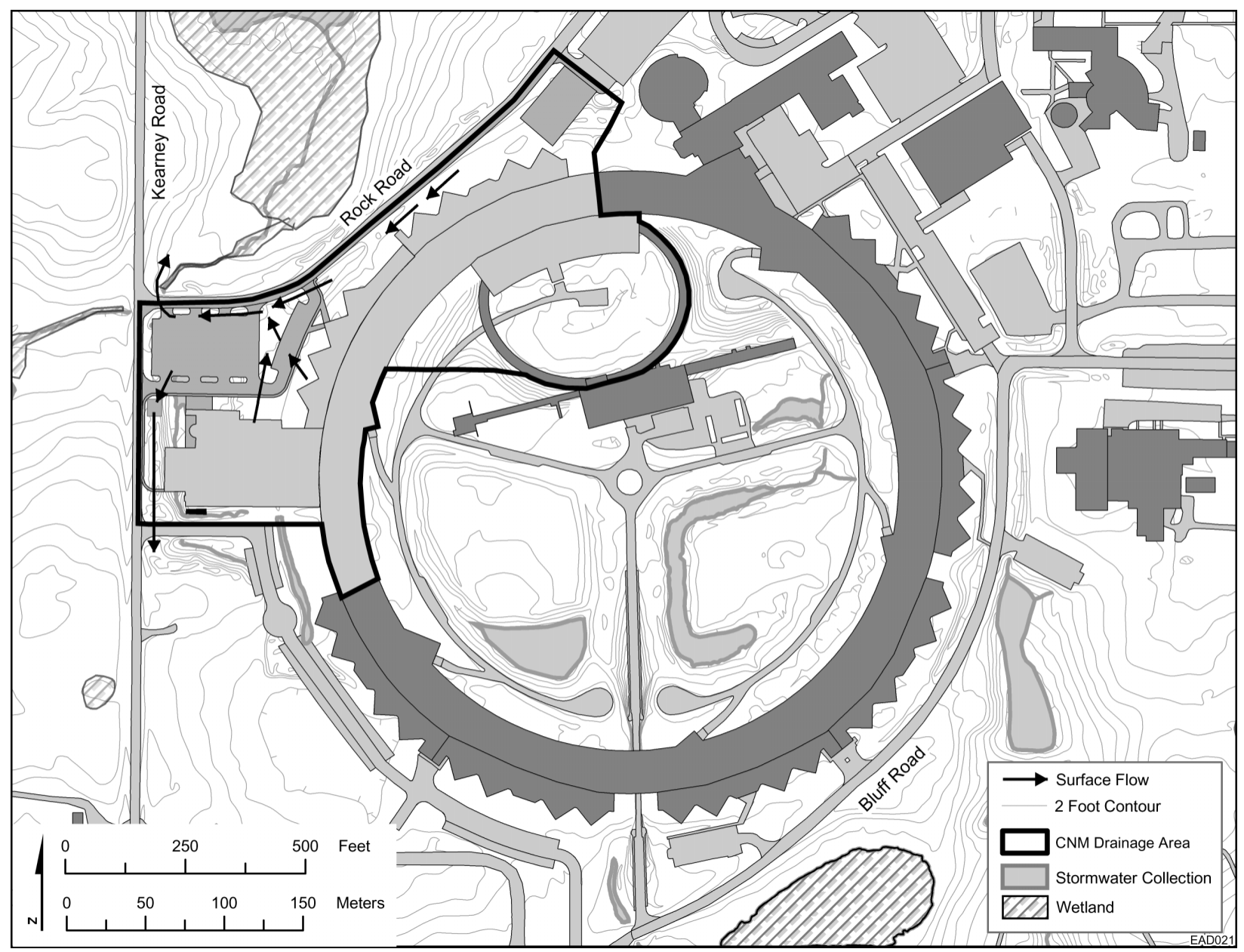

FIGURE 5.1 Direction of Stormwater Flow (arrows) in the Area of the CNM Facility

south across the ANL site boundary. The effect of alternative parking configurations on water quality are discussed below. Stormwater flows from the CNM site would meet water quality criteria that are protective of wetlands, including wetland communities and component biota. In addition, stormwater flows from the CNM drainage area would be diluted upon entering the receiving stream at the drainage system outflow point. The planting of native species in stormwater collection areas and other landscaped areas on the CNM site would promote the infiltration of precipitation.

Table 5.1 lists contaminants that originate on road and parking surfaces and may be included in stormwater runoff (Nelson 2002; Sonstrom 2002). Also given are the benchmark concentrations protective of wetlands and aquatic biota. Most of the benchmarks are the National Ambient Water Quality Criteria (NAWQC) established by the EPA; however, several contaminants do not have established national criteria. The ethylene glycol benchmark is the State of Michigan Water Quality Standard (the State of Illinois does not have a water quality standard for ethylene glycol); total phosphorus and total nitrogen are the EPA nutrient criteria for 
TABLE 5.1 Water Quality Criteria for Aquatic Biota for Common Parking Lot Runoff Constituents

\begin{tabular}{|c|c|c|c|}
\hline Constituent & $\begin{array}{c}\text { Benchmark } \\
\text { Value }(\mathrm{mg} / \mathrm{L}) \\
\end{array}$ & Benchmark Type ${ }^{a}$ & Sourceb \\
\hline Chloride & 230 & National WQC & EPA 1988 \\
\hline Copper & $0.009^{c}$ & National WQC & EPA 2002 \\
\hline Ethylene glycol & 190 & Michigan WQS & MDEQ 2002 \\
\hline Lead & $0.0025^{\mathrm{c}}$ & National WQC & EPA 2002 \\
\hline Zinc & $0.120^{\mathrm{c}}$ & National WQC & EPA 2002 \\
\hline Total phosphorus & 0.07625 & Ecoregional Nutrient Criteria & EPA 2000a \\
\hline Total nitrogen & 2.180 & Ecoregional Nutrient Criteria & EPA 2000a \\
\hline Oil/grease & $15^{\mathrm{d}}$ & Illinois WQS & IPCB 1996 \\
\hline \multicolumn{4}{|c|}{ a $\quad \mathrm{WQC}=$ water quality criteria; $\mathrm{WQS}=$ water quality standard. } \\
\hline \multicolumn{4}{|c|}{ b MDEQ = Michigan Department of Environmental Quality; IPCB = Illinois } \\
\hline \multicolumn{4}{|c|}{ Value assumes a water hardness of $100 \mathrm{mg} / \mathrm{L}$. } \\
\hline Illinois indigen & aquatic li & standard (IPCB 1996). & \\
\hline
\end{tabular}

Ecoregion VI, which includes northern Illinois; and the benchmark for oil/grease is the Illinois Water Quality Standard for Indigenous Aquatic Life. Salt used for deicing enters the wetland or aquatic environment as sodium and chloride ions in solution following snowmelt or rain events. However, chloride has a greater impact on biota than sodium (TRB 1991; Richburg et al. 2001) and is a more reliable measure of salt in the environment. No NAWQC for sodium has been established by the EPA.

Under the proposed action, most contaminants in stormwater runoff from the CNM parking area would be prevented from entering the receiving stream north of Rock Road. These contaminants would be included in the stormwater runoff that would be pumped to the south of the CNM site and outside the watershed of Wetland 302. The first 0.5 in. $(1.3 \mathrm{~cm})$ of stormwater runoff from impervious surfaces, such as parking areas, carries approximately $90 \%$ of the contaminant load of stormwater (IDEQ 2001). Pumping of runoff from the CNM parking area would include the first $0.5 \mathrm{in} .(1.3 \mathrm{~cm})$, and a minimum of approximately the first inch $(2.5 \mathrm{~cm})$ of rainfall, including 100-year, 24-hour storm events. Therefore, less than $10 \%$ of the 
contaminants from the CNM parking area would remain in the runoff remaining in the Wetland 302 watershed. These contaminant levels would be well below benchmark levels.

An analysis of impacts to surface water from winter salt application is provided in Appendix D. Under the proposed action, with present salting rates, chloride concentrations, averaged over the winter season, entering Wetland 302 from the receiving stream north of Rock Road would be between $50 \mathrm{mg} / \mathrm{L}$ and $126 \mathrm{mg} / \mathrm{L}$, depending on the soil temperature and potential infiltration.

Under parking alternative B, bioretention swales would be incorporated into the CNM facility parking area to receive stormwater flows from this parking area and adjacent areas. By temporarily retaining stormwater flows, the bioretention swales would reduce flow fluctuations and the amplitude of peak flows and would permit a gradual release of water. Stormwater peak flows would generally be lower than those presently occurring at the outflow of the existing stormwater collection basin, which only slightly reduces flow peaks. In addition, the soil and vegetation of the bioretention swales would filter out suspended particulates and contaminants from stormwater and contribute to the degradation of organic contaminants. Highly soluble materials, such as road salt and ethylene glycol, may largely pass through bioretention swales, although a portion of the ethylene glycol may be degraded. A wide range of removal efficiencies has been observed in bioretention swales, depending on engineering parameters and success of vegetation establishment (SMRC 2002; EPA 1999, 2000b). Contaminant concentrations in stormwater runoff from roads and parking lots, removal rates, and resulting concentrations are given in Table 5.2. Contaminant concentrations calculated for the low removal rates using the high value for initial runoff concentrations would be below respective benchmark values, except for nitrogen and phosphorus. However, the contaminants remaining in the stormwater would be diluted by the addition of flows from roof runoff, prior to release into the receiving stream. Resulting concentrations of nitrogen and phosphorus would be below benchmark values. In addition, the replaceable filter that would be included in the drainage system would further lower concentrations of petroleum-based oils and grease.

Chloride concentrations in runoff from the CNM facility drainage area were estimated for parking alternative B. Chloride concentrations, averaged over the winter seasons, entering Wetland 302 from the receiving stream north of Rock Road would be between 83 and $201 \mathrm{mg} / \mathrm{L}$. For parking alternative $C$ and $D$, chloride concentrations from the $16,000 \mathrm{ft}^{3}\left(453 \mathrm{~m}^{3}\right)$ of parking north of the CNM would be between 28 and $74 \mathrm{mg} / \mathrm{L}$ in the receiving stream.

Following storm events, stormwater runoff from developed areas has the potential to increase water elevation fluctuations in wetlands within the watershed. Therefore, potential changes in surface water elevation in Wetland 302 from construction of the CNM, LOM 437, and associated parking areas were evaluated. Under the proposed action, construction of the CNM, LOM 437, and associated parking areas would result in a negligible change in the increase in surface elevation of Wetland 302 compared with current conditions, primarily because the increase in impermeable area represents a small percentage of the watershed (Kottmeyer 2003). Thus the impact on wetland hydroperiod characteristics would be negligible. 
TABLE 5.2 Road and Parking Surface Runoff Concentrations, Bioretention Swale Reduction Rates, Resulting Concentrations, and Discharge Concentrations

\begin{tabular}{lccccc}
\hline Constituent & $\begin{array}{c}\text { Runoff } \\
\text { Concentration } \\
(\mathrm{mg} / \mathrm{L})^{\mathrm{a}}\end{array}$ & $\begin{array}{c}\text { Rioswale } \\
\text { Removal } \\
\text { Rate }\end{array}$ & $\begin{array}{c}\text { Maximum } \\
\text { Resulting } \\
\text { Concentration } \\
(\mathrm{mg} / \mathrm{L})^{\mathrm{b}}\end{array}$ & $\begin{array}{c}\text { Discharge } \\
\text { Concentration } \\
(\mathrm{mg} / \mathrm{L})\end{array}$ & $\begin{array}{c}\text { Benchmark } \\
\text { Value } \\
(\mathrm{mg} / \mathrm{L})\end{array}$ \\
\hline Copper & $0.007-0.013$ & $43-97$ & 0.0074 & 0.002 & 0.009 \\
Ethylene glycol & 70.2 & 0 & 70.2 & 22.1 & 190 \\
Lead & $0.003-0.005$ & $67-95$ & 0.00165 & 0.0005 & 0.0025 \\
Zinc & $0.108-0.151$ & $63-98$ & 0.0559 & 0.018 & 0.120 \\
Total phosphorus & $0-0.143$ & $29-87$ & 0.102 & 0.032 & 0.07625 \\
Total nitrogen & $1.6-5.63$ & $49-84$ & 2.87 & 0.905 & 2.180 \\
Oil/grease & $2.43-4.3$ & $75-90$ & 1.08 & 0.341 & 15 \\
\hline
\end{tabular}

a Sources: Nelson (2002); Sonstrom et al. (2002).

b Maximum concentrations were determined by using the high runoff concentration value and the low removal rate.

In addition, the stormwater detention area for roof drains that would be constructed under the proposed action, as well as the removal of a portion of parking area runoff by pumping, would contribute to attenuating storm flow peaks. Parking alternative B would also result in a negligible change from current conditions. Flow attenuation would be promoted by the detention capacity of the bioretention swales and the detention area for roof runoff. Because parking alternatives $\mathrm{C}$ and D have the same configuration within the CNM watershed, they would have similar effects on Wetland 302 surface water elevations. The detention area for roof drains, in addition to the reduced parking area north of the CNM facility, would contribute to attenuating storm flow peaks.

\subsubsection{Groundwater}

Continued operation of the APS facility would not involve the use of groundwater or the release of effluents to groundwater sources; thus, no direct impacts to groundwater are expected.

Any radioactivity in soil could be leached out by water and could result in groundwater contamination. However, as discussed in Sections 4.3.2 and 5.1.1, soil contamination is negligible under current APS operations. The proposed action would not change the design and 
operation of the APS components; therefore, soil contamination would continue to be negligible, so would groundwater contamination.

No groundwater would be used for CNM facility construction, nor would construction activities routinely discharge any effluents to groundwater. Construction of the CNM facility would not be expected to alter the direction or quantity of groundwater flow. The bottom of the CNM building footings would be $4 \mathrm{ft}(1.2 \mathrm{~m})$ below the proposed finished floor elevation of $744 \mathrm{ft}(267 \mathrm{~m})$. The glacial drift at the APS site is dominated by low-permeability glacial till. A thin, fairly continuous permeable sand layer is located below the APS facility at an elevation of about $720 \mathrm{ft}(219 \mathrm{~m})$ (Killey and Trask 1994). Minor, isolated sand units may be present at elevations above $720 \mathrm{ft}(219 \mathrm{~m})$; however, the presence of shallow sands is unlikely because none were encountered in the drilling program of Killey and Trask (1994). Therefore, construction of a foundation at an elevation of $740 \mathrm{ft}(256 \mathrm{~m})$ would not be expected to change groundwater flow within the glacial drift. Small accidental spills of materials or chemicals used during construction would be promptly cleaned up so that soils or groundwater would not be contaminated.

The infiltration of precipitation would be prevented on impervious surfaces in the CNM drainage area. However, because of the relatively impermeable disturbed soils currently present in the area of proposed construction and the predominance of non-native grasses in the vegetation cover, current infiltration rates are likely low. The increase in impervious surface would be expected to have a minor effect on infiltration to groundwater in the CNM drainage area. The planting of native species in stormwater collection areas and other landscaped areas on the CNM site would promote the infiltration of precipitation.

No adverse impacts to groundwater are expected as a result of implementing the proposed action.

\subsubsection{Air Quality and Noise}

Continued operations of the APS would result in very low emissions of criteria air pollutants. As shown in Table 4.1, the emissions from the APS facility and the associated emergency generators constitute at most about $6 \%$ of total ANL-E emissions, and emissions from ANL-E are less than $0.1 \%$ of the total emissions in the three closest counties.

A construction permit would be required before beginning construction of the CNM facility. The Urban Emissions Model (URBEMIS 2001, Version 6.2.1) (Jones \& Stokes 2000) was used to estimate emissions during construction of the CNM facility. Emissions from site grading, worker trips, stationary equipment, mobile equipment, and architectural coatings were estimated. Emissions of $\mathrm{PM}_{10}$, volatile organic compounds (VOCs), $\mathrm{NO}_{\mathrm{x}}, \mathrm{CO}$, and $\mathrm{SO}_{2}$ would all be less the 3 tons $/ y r(2,700 \mathrm{~kg} / \mathrm{yr})$. Under the EPA's general conformity program, projects with emissions less than 100 tons/yr $(91,000 \mathrm{~kg} / \mathrm{yr})$ are exempted from review because their emissions have been deemed to have negligible air quality impacts. Emissions associated with CNM facility construction would be of short duration and have negligible air quality impacts. 
Construction equipment would emit noise; the effects of this noise, however, would be temporary and local. Elevated noise levels may be noticed by hikers, bikers, horseback riders, and other users of the adjacent Waterfall Glen Forest Preserve. However, the forest preserve would provide a buffer zone between the construction activities and the nearest residents, schools, and religious institutions, which are more than $1 \mathrm{mi}(1.6 \mathrm{~km})$ away. Noise impacts on these sensitive receptors would be negligible.

The CNM would use existing emergency generators; thus no increase in emissions would be expected. A new 1-MW (3.5-MMBtu/h) natural-gas-fired boiler for humidification would be associated with the CNM complex. ${ }^{1}$ This boiler would not be operated during the summer and would normally operate at less than peak capacity. Even if operated at capacity for a full year, emissions of all criteria pollutants would be less than 1.5 tons $/ \mathrm{yr}(1,400 \mathrm{~kg} / \mathrm{yr})$. These emissions would all be less than the 100 tons/yr $(91,000 \mathrm{~kg} / \mathrm{yr})$ de minimis cutoff used in the EPA's general conformity program and would have only negligible off-site air quality impacts.

Another emission from the CNM would be standard space ventilation from occupied areas. In addition, research processes in cleanrooms would produce emissions that may involve small amounts of materials. Those emissions would exit the facility through scrubbers or highefficiency particulate air (HEPA) filters, which would reduce emissions by more than $99 \%$. Thus, emissions from the CNM would be expected to have negligible off-site air quality impacts. Chemicals expected to be used in the CNM are listed in Appendix B.

The BioCARS facility is already fully operational. Given a finite number of experimental stations, when BioCARS begins experiments with BSL-3 agents under the Proposed Action, an equal number of ongoing experiments (involving noninfectious organisms) will cease. Air pollution control devices will continue to function at current performance levels. Air quality impacts from current BioCARS activities are negligible. There will be no net change in air quality impacts as a result of the Proposed Action regarding BioCARS activities.

Noise sources associated with the CNM would include ventilation fans, transformers, chillers, and fans associated with space conditioning equipment. Similar sources already exist at the APS. The addition of a small number of new sources would cause only an imperceptible increase in noise levels off-site.

No adverse air quality or noise impacts are expected as a result of implementing the proposed action.

\subsubsection{Land Use, Recreation, and Aesthetics}

The continued operation of the APS is consistent with the dedication of ANL-E to research and development and would not interfere with recreational use of the Waterfall Glen

1 The boiler will be incorporated into the sitewide Title V Air Operating Permit, if required, depending on final design specifications. 
Forest Preserve. The APS facilities would remain visible from adjacent areas during continued operation.

Initiation of BSL-3 research and construction of the CNM facility are also consistent with the use of ANL-E for energy research and development and consistent with the mission of the APS as a major national user facility. Construction activities and associated noise related to the CNM may be noticed by users of the areas of the Waterfall Glen Forest Preserve that are immediately adjacent to the APS site. These effects, however, would be minor and temporary.

The CNM facility would be located adjacent to existing APS facilities and would have a negligible effect on the visual characteristics of the site. Viewers of the APS facilities from the Waterfall Glen Forest Preserve adjacent to the APS facilities are unlikely to notice the new facilities, which would be designed to achieve aesthetic harmony with the APS.

\subsubsection{Ecological Resources}

\subsubsection{Terrestrial Biota}

Continued operation of the APS facility would have negligible effects on terrestrial habitats and wildlife. Habitat disturbance on the APS site, including landscape maintenance activities, would not be expected to change from past disturbance levels. Wildlife would continue to avoid areas of human activity and would continue to be disturbed by vehicle use (user transportation or shipping) and noise sources (such as backup generators or cooling systems, traffic). The predominance of non-native species in vegetated areas of the APS site would be maintained by the continuation of past management practices.

Construction of the CNM facility and support areas, including parking areas, would require the disturbance of 2 to 4 acres ( 0.8 to 2 ha) of land. Existing vegetation and wildlife on the proposed construction sites would be eliminated. Habitat that would be lost on the proposed location is primarily managed grassland maintained by periodic mowing. Similar habitat is common on the ANL-E site. During construction of the parking area and proposed bioswales, several mature trees also would likely be removed. Construction of the CNM would result in only minor impacts to terrestrial biota because of the low species diversity and poor quality of managed grassland habitat for many species of wildlife. The use of native vegetation species for landscape plantings on the CNM facility site would increase species diversity on the APS site and avoid the introduction of invasive non-native species.

During operation of the CNM, there would be no direct discharge of wastewater effluent to the environment. Wastewater would be treated at the ANL-E wastewater treatment plant. Effects on air quality from operation of the CNM would be negligible. Therefore, operation of the CNM would be expected to have negligible impacts on biota beyond those of continued APS operations. 


\subsubsection{Wetlands and Aquatic Biota}

Executive Order 11990, Protection of Wetlands, requires federal agencies to minimize the destruction, loss, or degradation of wetlands and to preserve and enhance the natural and beneficial uses of wetlands. DOE regulations for implementing Executive Order 11990, as well as 11988, Floodplain Management, are set forth in 10 CFR 1022.

Continued operation of the APS facility would not be expected to result in changes to existing conditions of wetlands and aquatic biota. The water quality and flow characteristics of surface water and groundwater inflows to Wetland 302 northwest of the APS facility and Wetland $\mathrm{R}$ to the southeast would be improved through implementation of the management plans for those two wetlands.

Construction of new LOMs would not result in direct impacts to wetlands. Indirect impacts to Wetland 302 from sedimentation would be negligible with the implementation of approved ANL-E erosion and sediment control practices.

No wetlands would be filled by construction of the CNM facility. Construction of the facility and support areas, including parking areas and LOMs, could potentially result in increased sedimentation in Wetland 302, northwest of the APS. However, implementation of approved ANL-E practices for stormwater and erosion control during construction would be expected to result in negligible water quality impacts (Section 5.1.2.2). As a result, CNM construction activities would be expected to result in only negligible impacts to wetlands and aquatic biota.

Wetland 302 is managed as mitigation for potential future wetland impacts at the ANL-E site. Issues that affect the acceptability of this wetland as mitigation include (1) quantity of water supplied to the wetland, (2) variability of flows, (3) water quality, and (4) establishment of desirable wetland species. The watershed of Wetland 302 includes a portion of the APS site, the CNM drainage area (Figure 5.1). The development and maintenance of the desired characteristics of Wetland 302 are a high priority for ANL-E. A Wetland Management Plan being developed for Wetland 302 addresses environmental factors that may potentially impact the wetland and provides management actions to mitigate potential impacts and maintain required wetland characteristics.

Under the Proposed Action, most of the surface water originating within the CNM drainage area of the Wetland 302 watershed would continue to be directed into Wetland 302. A portion of the stormwater runoff from the CNM parking area would be pumped to the south and removed from Wetland 302 watershed. However, the amount of water removed would represent a small portion of the total hydrologic input to Wetland 302. The CNM parking area would constitute about $0.7 \%$ of the watershed of Wetland 302. The effect on infiltration to groundwater would be expected to be minor, and no changes are expected in groundwater flow as a result of the proposed action (Section 5.1.2.3). In addition, the planting of native species in stormwater collection areas and other landscaped areas on the CNM site would promote the infiltration of precipitation. The proposed action would not be expected to change the function or biotic communities of Wetland 302. 
As a result of the Proposed Action, the total amount of impervious surfaces within the watershed of Wetland 302 would increase from $13.1 \%$ to $14.8 \%$ of the watershed. Stormwater runoff from developed areas following storm events has the potential to increase water elevation fluctuations in wetlands within the watershed. As discussed in Section 5.1.2.2, construction of the CNM, LOM 437, and associated parking areas would result in a negligible change in the rise in surface elevation of Wetland 302 following storm events, compared with current conditions. The stormwater detention area for roof drains that would be constructed under the proposed action, as well as the removal of a portion of parking area runoff by pumping, would contribute to attenuating storm flow peaks.

Under the proposed action, most contaminants in stormwater runoff from the CNM parking area would be prevented from entering the receiving stream north of Rock Road (see Section 5.1.2.2). Most of these contaminants would be included in the stormwater runoff that would be pumped south of the CNM site and outside the watershed of Wetland 302. Less than $10 \%$ of the contaminants from the CNM parking area would remain in the runoff that enters Wetland 302. These contaminant levels would be well below benchmark levels and would not be expected to result in adverse impacts to Wetland 302.

Under the Proposed Action, the total amount of roads, parking areas, and walkways receiving deicing salt within the watershed of Wetland 302 would increase approximately $3 \%$ and would change from 8.3 to $8.5 \%$ of the watershed. The total surface area within the watershed of Wetland 302 presently receiving salt is $8.3 \%$ of the watershed. The management of Wetland 302, including minimization of salt usage on-site, will be discussed in the sitewide wetland management plan.

Although deicing salt applied to roads, parking lots, and walkways enters the wetland or aquatic environment as sodium and chloride ions, chloride has a greater impact on biota than does sodium (TRB 1991; Richburg et al. 2001) and is a more reliable measure of salt in the environment. Although the NAWQC for chloride, $230 \mathrm{mg} / \mathrm{L}$, is considered protective of wetlands (EPA 1990), some wetland species can be affected by chloride concentrations of $168 \mathrm{mg} / \mathrm{L}$ (Wilcox 1986), potentially affecting wetland vegetation communities. Salt-tolerant species may increase in abundance while intolerant species decrease.

The concentration of chloride in runoff from the CNM drainage area currently entering the receiving stream was calculated to be between $197 \mathrm{mg} / \mathrm{L}$ and $356 \mathrm{mg} / \mathrm{L}$, depending on soil temperature (see Section 5.1.2.2). Implementation of the Wetland 302 Management Plan would result in reduced chloride levels in the wetland, including the input from the CNM drainage area. In addition, chloride concentrations in Wetland 302 would likely be lower during the growing season. Because the sodium chloride $(\mathrm{NaCl})$ brought into the $\mathrm{CNM}$ building may interfere with the scientific mission, it is also the intent of the program to develop alternative methods of controlling hazardous conditions caused by snow and ice. These methods would likely further reduce chloride concentrations in runoff from the CNM area. Stormwater runoff from the CNM drainage area combines with the runoff from the southwest portion of the Wetland 302 watershed. That runoff forms the receiving stream into which the CNM runoff discharges. These combined flows then enter Wetland 302. The concentration of chloride in runoff from the combined flows currently entering Wetland 302 was calculated to be between $70 \mathrm{mg} / \mathrm{L}$ and 
$184 \mathrm{mg} / \mathrm{L}$, depending on soil temperature. Thus, current chloride concentrations may exceed benchmark levels and result in adverse impacts to Wetland 302.

Under the proposed action, the concentration of chloride in runoff from the CNM drainage area entering the receiving stream was calculated to be between $148 \mathrm{mg} / \mathrm{L}$ and $224 \mathrm{mg} / \mathrm{L}$, depending on soil temperature. The concentration of chloride in runoff from the combined flows entering Wetland 302 was calculated to be between $50 \mathrm{mg} / \mathrm{L}$ and $126 \mathrm{mg} / \mathrm{L}$, depending on soil temperature. Of the four parking alternatives evaluated, the proposed action results in the lowest chloride concentrations. Operation of the CNM under the proposed action, including parking areas, would not be expected to result in the degradation of Wetland 302 biotic communities.

Under parking alternative $\mathrm{B}$, the construction of a series of bioretention swales in association with CNM facility construction would be expected to mitigate the effects of the increase in impervious surface by reducing amplitudes of stormwater flows (see Section 5.1.2.2). Bioretention swales are stormwater management features constructed to treat stormwater flows discharged to sensitive areas such as streams and other wetlands. Surface water from the CNM drainage area enters a small stream that flows into Wetland 302. The proposed bioretention swales would permit infiltration and reduce velocities of stormwater flows, as well as provide temporary retention to allow more gradual outflow of stormwater to the stream entering Wetland 302. Parking alternative B would result in a negligible change in the increase in surface elevation of Wetland 302 from current conditions. Flow attenuation would be promoted by the detention capacity of the bioretention swales and the detention area for roof runoff.

During CNM operation, most of the contaminants in stormwater runoff from the CNM drainage area, including parking areas, roadways, and roof drains, would be expected to be filtered out by the bioretention swales. Water quality characteristics of stormwater runoff entering the receiving stream from the CNM drainage area are discussed in Section 5.1.2.2. Concentrations of contaminants from the drainage area, prior to mixing in the stream, would be below water quality criteria that are protective of wetlands, including wetland communities and component biota. In addition, these concentrations would be further reduced by dilution in the receiving stream. Impacts to wetland biota due to exposure to contaminant concentrations below these benchmark values would be expected to be negligible.

Under parking alternative $\mathrm{B}$, the concentration of chloride in runoff from the $\mathrm{CNM}$ drainage area entering the receiving stream was calculated to be between $260 \mathrm{mg} / \mathrm{L}$ and $374 \mathrm{mg} / \mathrm{L}$, depending on soil temperature. The concentration of chloride in runoff from the combined flows entering Wetland 302 was calculated to be between $83 \mathrm{mg} / \mathrm{L}$ and $201 \mathrm{mg} / \mathrm{L}$, depending on soil temperature. As a result, operation of the CNM under parking alternative B may exceed benchmark levels for chloride and result in adverse impacts to Wetland 302. However, as noted above, impacts to Wetland 302 from deicing salts would be addressed in the Wetland Management Plan.

Because parking alternatives $\mathrm{C}$ and $\mathrm{D}$ have the same configuration within the CNM watershed, they would have similar effects on Wetland 302 surface water elevations. The 
detention area for roof drains, in addition to the reduced parking area north of the CNM facility, would contribute to attenuating storm flow peaks.

Under parking alternatives $\mathrm{C}$ and $\mathrm{D}$, the concentration of chloride in runoff from the CNM drainage area entering the receiving stream was calculated to be between $173 \mathrm{mg} / \mathrm{L}$ and $263 \mathrm{mg} / \mathrm{L}$, depending on soil temperature. The concentration of chloride in runoff from the combined flows entering Wetland 302 was calculated to be between $59 \mathrm{mg} / \mathrm{L}$ and $146 \mathrm{mg} / \mathrm{L}$, depending on soil temperature. The upper level, resulting from thawed soil, represents $87 \%$ of the benchmark value for chloride $(168 \mathrm{mg} / \mathrm{L})$. Operation of the CNM under parking alternatives $\mathrm{C}$ and D would not likely result in the degradation of Wetland 302 biotic communities; however, under thawed soil conditions, chloride concentrations would approach the benchmark level.

Comparison with Past Predictions. Stormwater from the existing main parking lot to the north of the APS discharges through a channel into the lower portion of Wetland 302 near the upstream end of Wetland 303. Before APS construction began, DOE estimated that stormwater impacts to these wetlands would be minor as a result of a planned stormwater management system that would attenuate stormwater surges and remove hydrocarbons from the parking lot runoff (Environmental Assessment Proposed 7-GeV Advanced Photon Source, DOE/EA-0389) (DOE 1990). A recent assessment indicated that the stormwater management system was not

installed as planned and that the quality of the two wetlands was somewhat degraded near the stormwater discharge point. DOE will more thoroughly evaluate stormwater impacts to Wetlands 302 and 303 and identify in the sitewide wetland management plan actions to address the impacts.

\subsubsection{Threatened and Endangered Species}

Continued operation of the APS facility would have negligible effects on federal- and state-listed species. Listed species are not likely to use habitats present on the APS site. Habitat disturbance on the APS site, including landscape maintenance activities, would not be expected to change from past disturbance levels. Wildlife would continue to avoid areas of human activity and would continue to be disturbed by vehicle use and noise sources.

Continued operation of the APS would not adversely affect either the quantity or the quality of water in the aquifer that feeds the Hine's emerald dragonfly (Somatochlora hineana) habitat. The dragonfly habitat is fed by the regional Silurian dolomite aquifer that is 150 to $200 \mathrm{ft}$ (46 to $61 \mathrm{~m}$ ) thick in southeast DuPage County (Zeizel et al. 1962). The dolomite is a regional aquifer, extending in Illinois from Lake County in the north to Kankakee and Iroquois Counties in the south (Willman 1967). At the APS, the dolomite is overlain by more than $100 \mathrm{ft}(30 \mathrm{~m}) \mathrm{of}$ glacial drift material (Killey and Trask 1994). Much of this drift is fine-grained, lowpermeability glacial till, with thin interbeds of discontinuous sands and gravels. Flow within the drift is predominantly lateral within the more permeable interbeds, with little or no connection to the dolomite aquifer (Quinn et al. 2001).

The ANL-E water supply is from Lake Michigan. Continued operation of the APS would not involve pumping water from the dolomite aquifer. Wastewater from the APS would continue 
to be treated at the ANL-E wastewater treatment plants and discharged to Sawmill Creek; stormwater would be managed to avoid impacts to surface waters.

Because of the configuration of the APS, soil or groundwater activation from operations is not expected (Section 4.2). In addition, because there is very little connection between the glacial till aquifer that underlies the APS and the dolomite aquifer that feeds the Hine's emerald dragonfly habitat, there would be no impacts on the dolomite aquifer from continued operation of the APS.

Construction and operation of the CNM facility would not affect Federal-listed species. Neither construction nor operation would adversely affect either the quantity or the quality of water in the aquifer that feeds the Hine's emerald dragonfly habitat. Neither construction nor operation of the CNM facility would involve pumping water from the dolomite aquifer. Wastewater from the CNM would be treated at the ANL-E wastewater treatment plants and discharged to Sawmill Creek. During construction and operation, stormwater would be managed to avoid impacts to surface waters. Because there is very little connection between the glacial till aquifer and the dolomite aquifer that feeds the dragonfly habitat, there would be no impacts on the dolomite aquifer from construction or operation of the CNM facility.

Although Kirtland's snake, state listed as threatened, may occur on the ANL-E site, its occurrence at the proposed CNM location would be unlikely because of the presence of preferred habitat nearby. Therefore, construction would be unlikely to adversely affect the Kirtland's snake. Construction of the CNM facility would have negligible affects on other state-listed species because they do not occur in the vicinity of the proposed CNM, and habitat for those species would not be impacted by construction. Operation of the CNM would not adversely affect Federal- or state-listed species.

\subsubsection{Cultural Resources}

No impacts to cultural resources are anticipated as a result of continued operations or new construction. The APS site has been surveyed, and archaeological sites were mitigated during APS construction. No historic structures would be impacted during construction of the CNM or operation of the CNM or BSL-3 facilities. The surrounding landscape of the nearby structures that were determined eligible for listing on the NRHP was not a factor in their eligibility status; therefore, CNM facility construction also would not have an adverse effect on these structures visually. Any APS activities or expansions beyond those proposed would require additional cultural resource analysis.

\subsubsection{Socioeconomics}

APS operations constitute an important part of ANL-E operations, which employ about 3,500 people and result in direct expenditures of about $\$ 500$ million. However, these numbers represent only a small portion of employment and economic activity in the Chicago region. In DuPage County alone, personal nonfarm income in 2000 was approximately $\$ 42$ billion dollars, 
while personal nonfarm income in the Chicago metropolitan area in 2000 was about $\$ 290$ billion dollars (BEA 2002). Continuing operation of the APS with up to 500 permanent staff represents a very small fraction of the economic activity in the county and region.

Construction of the CNM facility would employ about 50 construction workers. This employment would have negligible economic impact on the region. Income for persons employed in the general construction industry was $\$ 2.2$ billion for DuPage County and $\$ 12.7$ billion for the Chicago metropolitan area in 2000 (BEA 2002).

\subsubsection{Human Health}

\subsubsection{Continued Operations}

\section{Radiological Effects}

Radiological effects on human health associated with continuing operations would be well below the regulatory dose limits for APS operations. Continuing operations would not involve modifications to the designs of the APS primary components and would not affect their operations. Therefore, potential radiation doses to the APS workers, beamline users, on-site workers, and off-site public would stay at the same levels as discussed in Section 4.9.1. In summary, under normal conditions, the estimated maximum radiation doses to the APS workers, beamline users, on-site workers, and off-site public would be less than 100, 5.8, 1.6, and $3.0 \mathrm{mrem} / \mathrm{yr}$, respectively. The actual exposure levels would be much smaller than the estimated values. Under off-normal conditions, the impacts would be limited to the APS workers and the beamline users. Potential radiation doses associated with the MCI, which involves a beam loss within the LEUTL, would be about $218 \mathrm{mrem}$ for an incidence duration of one minute. Potential doses to on-site workers and off-site public would be less than 0.066 mrem. In reality, a beam loss is unlikely, and even if it occurs, would last much shorter than one minute. Therefore, potential impacts would be much less than $218 \mathrm{mrem}$ and $0.066 \mathrm{mrem}$. See Section 4.9.1 and Table 4.3 for conversion of doses presented throughout this section to human health risks.

Comparison with Past Predictions. Before APS operations began, potential radiation exposures to various receptors under normal and off-normal conditions were estimated and presented in a NEPA document, Environmental Assessment, Proposed 7-GeV Advanced Photon Source, DOE/EA-0389 (DOE 1990). Table 5.3 compares the preconstruction predictions made for the 1990 EA with the updated estimates presented in this EA. The updated estimates are either very close to or lower than the original estimates. The small differences in exposures to direct external radiation for APS workers, beamline users, on-site workers and the off-site public are due to minor changes in assumed exposure distances. The dose to the off-site public from air emissions is much lower in this EA because APS operations have changed such that production of air activation products is greatly reduced. 
TABLE 5.3 Comparison of Radiation Exposures Presented in This EA with Those Reported in the 1990 APS EA ${ }^{a}$

Receptor/Source or Event

\section{Normal Conditions}

APS workers/external radiation

Beamline users/external radiation

On-site workers/external radiation

Off-site public/external radiation

Off-site public/air emission

Off-Normal Conditions

APS workers/MCI

$218 \mathrm{mrem}^{\mathrm{g}}$

$0.066 \mathrm{mrem}^{\mathrm{g}}$

On-site workers/MCI
$100 \mathrm{mrem} / \mathrm{yr}$

$5.8 \mathrm{mrem} / \mathrm{yr}^{\mathrm{b}}$

$1.6 \mathrm{mrem} / \mathrm{yr}^{\mathrm{d}}$

$6.25 \mathrm{mrem} / \mathrm{yr}^{\mathrm{e}}$

$0.007 \mathrm{mrem} / \mathrm{yr}^{\mathrm{f}}$
DOE $1990^{\mathrm{b}}$
$120 \mathrm{mrem} / \mathrm{yr}$

$6 \mathrm{mrem} / \mathrm{yr}^{\mathrm{c}}$

$1.5 \mathrm{mrem} / \mathrm{yr}^{\mathrm{d}}$

$6 \mathrm{mrem} / \mathrm{yr}^{\mathrm{e}}$

$0.06 \mathrm{mrem} / \mathrm{yr}^{\mathrm{f}}$

a Radiation exposures listed in this table are estimated maximum exposures. The 1990 EA was prepared prior to APS construction and operation (DOE 1990).

b Radiation dose corresponds to a distance of $66 \mathrm{ft}(20 \mathrm{~m})$ from the storage ring and an exposure duration of $2,000 \mathrm{~h} / \mathrm{yr}$.

c Radiation dose corresponds to a distance of $46 \mathrm{ft}(14 \mathrm{~m})$ from the storage ring and an exposure duration of $2,000 \mathrm{~h} / \mathrm{yr}$.

d Radiation dose corresponds to a distance of $460 \mathrm{ft}(140 \mathrm{~m})$ from the storage ring and an exposure duration of 2,000 h/yr.

e Radiation dose corresponds to the nearest fence line $460 \mathrm{ft}$ (140 m) from the storage ring and an exposure duration of $8,000 \mathrm{~h} / \mathrm{yr}$.

f Radiation dose corresponds to the nearest fence line with the maximum air concentration.

$\mathrm{g}$ The MCI assumed in this report involves the loss of an electron beam in the LEUTL.

$\mathrm{h}$ The MCI assumed in DOE (1990) involved the loss of a positron beam in the insertion device. The listed dose of 1,170 mrem for an APS worker was found to be a mistake by checking the source document (Moe 1990) that provides this information. The dose to the APS worker should have been 183 mrem instead. 
In the $1990 \mathrm{EA}$, the MCI was based on a scenario in which a positron beam was lost and hit the walls of an insertion device. Later study has shown this is an impossible scenario because the beam would never be able to travel that far. With the inclusion of the LEUTL in the APS systems, the revised MCI is based upon a scenario in which the electron beam is lost within its enclosure, which is the scenario considered in this EA.

\section{Nonradiological Effects}

Normal Conditions. Under normal operational conditions, potential impacts to human health would be limited to potential physical hazards for the APS workers and beamline users conducting research activities, which would not extend beyond the laboratory areas. The potential release of hazardous materials to the environment through air emissions and wastewater discharge would be very small.

Potential impacts to the APS workers and beamline users would result from chemical exposures and physical injuries. Chemical exposures would occur through the inhalation, ingestion, and dermal absorption pathways; physical injuries would result from accidents during conduct of experiments under special temperature and pressure conditions with or without the use of special equipment.

Engineering designs were incorporated into the APS facilities to reduce potential air dispersion of chemical vapors and powders, thereby substantially lowering potential chemical exposures through the inhalation pathway. Such designs include the installation of fume hoods, incorporation of an air ventilation system to allow directional air flow to the laboratory, and the installation of HEPA filters to eliminate airborne particulate matter. Ingestion of chemicals would be unlikely to occur with the adoption of good hygiene practices. Dermal absorption of chemicals would be reduced to a minimum by wearing personal protective equipment (PPE), such as a laboratory coat and gloves, while conducting experiments. Potential physical hazards would be reduced to a minimum by incorporating safety measures into the experiment designs and by following safe handling procedures during the experiments. Under these conditions, potential impacts to workers and beamline users would be very small and would not result in deleterious effects to human health.

Implementation of an experiment safety review is the first step in integrating safety into management activities and would minimize the occurrence of laboratory accidents and reduce potential chemical exposures and physical hazards. To use the APS beamlines for research activities, researchers are required to submit proposals detailing experimental purposes, procedures, materials, and equipment that would be used. The proposals are reviewed by a committee with expertise in the related field. The experiment safety review has the following functions: (1) to identify and analyze hazards associated with planned experiments; (2) to define safety envelopes by selecting, specifying, and authorizing required hazard controls; (3) to perform experiments within the defined bounds of safety envelopes; and (4) to evaluate the safety performance of completed experiments to provide continuous feedback for improving safety. Under the oversight of ANL-E, each CAT management team would assume responsibility for evaluating the submitted proposals and ensuring that the experiments conducted at its 
beamlines and in its LOM space by CAT personnel, their collaborators, and independent investigators do not present unacceptable risks. A proposal would not be approved until all necessary safety measures for addressing the potential hazards identified by the review committee were incorporated into the experiment design. After approval of the proposal, the researchers would be required to take safety training courses defined in the selected safety envelopes before conducting the experiments. During the experiments, specific hazard controls according to the experiment design would be installed, and material and equipment safety handling procedures to reduce potential accidents would be closely followed.

The safety envelopes (APS 2000) cover potential hazards related to the conduct of experiments at the APS under the following situations: (1) at ambient temperature and pressure; (2) at cryogenic temperatures using liquid nitrogen; (3) at high temperatures involving the use of an electric furnace; (4) using Class 3 or 4 laser powers; (5) involving high-pressure systems; (6) using chemicals that are carcinogens, flammable liquids, oxidizers, corrosives, reactives, or compressed gases; (7) using infectious microorganisms; (8) using radioactive materials; and (9) any combination of the above situations. Standard precautions for personnel protection, standard laboratory operating procedures, safety training courses, and shipping guidance for experiment samples are specified in each envelope. The SOPs provide guidance on the safe use of specific chemicals and equipment and on the safe conduction of specific experimental procedures, such as etching, cleaving, and polishing. Additional SOPs related to research activities that are not covered under the current APS operation would be developed as needed in the future.

Designated safety coordinators in each LOM are responsible for monitoring experimental activities and assisting the beamline users in normal and emergency conditions. Their existence provides an additional layer of protection for human health and the environment.

Off-Normal Conditions. Typical laboratory accidents could occur; however, the primary impacts from such accidents are expected to be limited to the laboratory workers and beamline users involved in the experiments. The potential release of chemicals, if any, to the environment are expected to be very small and would be of short duration because (1) the amount of chemicals handled in the experiments would be small, (2) the engineering designs of the facilities would control and reduce the release, and (3) the accidents would be mitigated quickly by designated safety coordinators and by the ANL-E emergency response system. Therefore, potential impacts to other on-site workers and the off-site general public are expected to be negligible. The safety measures discussed under "Normal Conditions" are designed to reduce the frequency of such accidents. In fact, since the beginning of its operation, no major accident has occurred in the APS facilities.

\subsubsection{Enhanced Operations: BSL-3 Operations}

Currently, the BioCARS facility is used for BSL-2 research, although it was constructed and furnished for BSL-3 research as well. For the Proposed Action, BSL-3 research would be conducted in this facility. Research activities in the BSL-3 facility would involve indigenous or exotic agents that may cause serious or potentially lethal disease as a result of exposure by the 
inhalation route if released to the environment. Further descriptions of the activities and impacting factors associated with the BSL-3 facilities are provided in Appendix A.

\section{Normal Conditions}

The unique concern of potential human heath risks associated with the operation of a BSL-3 facility are the injuries and illnesses associated with handling infectious substances by the laboratory workers and the contraction of illnesses by other on-site workers and the off-site general public through contact with infected laboratory workers or through the environmental release of infectious substances. Although the BSL-3 facility at the APS would not be required to register with the CDC because there is currently no plan to use select agents in the facility, its operation would be in accordance with CDC guidelines and the safety requirements of ANL-E as established by the Institutional Biosafety Committee (IBC). The type of potential human health risks associated with the operation of the existing BSL-3 facility would be the same type as that associated with other CDC-registered laboratories, such as hospital and medical laboratories. For APS facilities, however, the potential risks of these types of adverse effects would be lower because the APS facility would not be a large-scale biological research or production facility; therefore, the quantity of each organism would be limited. Furthermore, the APS facility would be used mainly for sample preparation prior to structure examination by photon beamlines; cultivation of microorganisms would be conducted at the home institution of the beamline user and sent to the APS. The quantities of the microorganisms to be used at any time in the BSL-3 facility would be small, limited to less than $10 \mathrm{~mL}$.

The incidence of acquired infections associated with operations in CDC-registered laboratories has been extremely low since the implementation of CDC-developed guidelines issued in 1974. A recent bibliographic database (Collins 2000) based on reports starting from about the beginning of the 20th century to August 2000 reveals substantial reductions in laboratory-acquired infections reported in the 1990s. There is a particularly notable lack of reported cases in the literature in the United States in the last 10 years. Therefore, the potential human health impact associated with routine operation of a BSL-3 facility would be best characterized as minor. A detailed description of the safety controls of the BSL-3 is included in Appendix A.

Potential pathways for infectious agents to escape the BSL-3 facility and cause human health impacts are direct transmission, vector-borne transmission, vehicle-borne transmission, airborne transmission, and water-borne transmission. By following the established agenthandling procedures; operating the facility in accordance with all safety requirements, including implementation of experiment safety review and safety training courses as described in Section 5.1.8.1; and conducting regular and thorough facility maintenance activities, potential human health impacts would be reduced to a minimum. The following paragraphs discuss the potential transmission pathways and the respective mechanisms for their elimination.

Direct Transmission. Direct transmission requires a worker to be exposed to an infectious agent through inhalation, ingestion, or dermal contact (e.g., through cuts in the skin). Using biosafety cabinets, following specific agent-handling requirements, and implementing 
facility safety procedures would minimize the likelihood of worker exposure. Although laboratory-associated infections could occur and an infected worker could become a carrier for the agents and expose other people through direct transmission, such events would be considered as abnormal because of their low frequency of occurrence. Discussions on off-normal events are provided in the "Off-Normal Conditions" section below.

Vector-Borne Transmission. With an effective pest control program, the possibility of human exposure through insects and rodents would be severely limited. Because of the location and design of the BioCARS facility, entry by pests is extremely unlikely. The ANL-E PFS administers a contract with an exterminating company. They are on-site once a week (on Tuesdays), and they cover certain areas on a routine basis. In addition, they can be called in on Tuesdays to cover any areas that need service that are not part of their regular coverage. Service for the APS area is obtained by calling the building administrator, who then makes contact with PFS for the work that is needed.

Vehicle-Borne Transmission. Vehicle-borne transmission could result from contamination of clothing, skin, hair, or any other material that leaves the BSL-3 facility. According to the SOP of BioCARS, all potentially contaminated waste materials would be captured, properly treated, packaged, and shipped to an outside vendor for final disposal. All facility personnel would be required to wear personal protective equipment (PPE), if necessary, while conducting research activities in the facility, and they would remove and leave this protective equipment behind before departing the facility. By following these guidelines, the potential for vehicle-borne transmission would be substantially reduced.

Air-Borne Transmission. All air leaving the BSL-3 facility would be HEPA-filtered. With the high efficiency $(99.97 \%)$ of HEPA filters, the number of microorganisms in their vegetative state in the exhaust air would be nearly zero. Many environmental factors, such as ultraviolet light, dehydration, high or freezing temperatures, and free oxygen, would kill the microorganisms and further reduce their existence. A mathematical prediction of the potential survival of microorganisms in the environment is estimated to be about $0.01 \%$ (Mitscherlich and Marth 1984). With the filtration power of HEPA filters and the low survival rates of microorganisms in the ambient environment, the possibility of air-borne transmission is very low. To maintain the filtration function, the HEPA filters would be routinely checked and replaced.

Water-Borne Transmission. The wastewaters discharged from the BioCARS facility would not contain pathogenic microorganisms. Standard practices at BioCARS require that waste liquids generated from BSL-2 or BSL-3 research be accumulated, disinfected, and managed through ANL-E's waste management program. Contaminated liquids are prohibited from being flushed down laboratory sink drains, and all discharges to the ANL-E wastewater treatment system would be in compliance with pertinent ANL-E protocols. Water from the laboratory sink drains of the BioCARS facility (e.g., glassware cleaning solutions) would be discharged to the ANL-E industrial wastewater treatment plant, where it would be treated and discharged through Outfall 001B. The flow of Outfall 001B would be combined with the flow of Outfall 001A for sanitary wastewater and discharged into Sawmill Creek approximately 3,500 ft $(1,100 \mathrm{~m})$ south of the wastewater treatment plant (Outfall 001). 
The experience of the U.S. Department of the Army (Army) at its Biological Defense Research Program (BDRP) facilities over several decades provides further insight into the potential for laboratory-acquired infection. The final programmatic environmental impact statement (PEIS) prepared by the Army to evaluate its BDRP facilities (Army 1989) states that since 1976, there have been no occurrences of overt disease in laboratory workers handling infectious organisms; although in 1980, one focal infection with $F$. tularensis occurred at the site of a puncture wound. The BDRP PEIS also estimated laboratory-acquired infection rates for its facilities for different biocontainment levels (roughly equivalent to the CDC BSL levels) over different periods of time. For its BSL-3 equivalent laboratory operations, the estimated rate was 1 infection per 500,000 person-hours worked from 1960 to 1962. For its BSL-4 equivalent laboratory operations, the estimated rate was 1 infection per 1,000,000 person-hours worked from 1960 to 1969. These infections included subclinical infections and mild illnesses where hospitalization was not required (Army 1989). Assuming the workers worked an average of 2,000 hours per year, the above figures converted to a rate of 1 infection per 250 person-years for BSL-3 equivalent laboratory operations, and 1 infection per 500 person-years for BSL-4 equivalent laboratory operations. With much fewer working hours, as would be the case for most APS BSL-3 facility users (typically two to three days per experiment and an expected maximum of two experiments per year), the infection rate would be further reduced.

The BDRP PEIS also estimated the rate of public infection resulting from its laboratory operations to be less than 1 per billion person-years and the risk of death to a laboratory worker to be 1 per 200 million person-years for the Defensive Period (1970 to 1989). The risk of death to a laboratory worker during the Offensive or Weapons Period (1954 to 1964) was estimated to be about 5 orders of magnitude higher, 1 per 2,000 person-years. Potential risks involving the BSL-3 facilities at the APS would be much lower than the risks reported for the Army facilities. This would be because of the lower volume of infectious agents that would be handled at the APS facilities than that handled at the Army BDRP laboratories, the shorter duration of the experiments, the fewer experimental procedural steps, and the lower level of research activities that would be conducted at the APS facilities compared with the level of research activities conducted at the Army facilities during the Defensive and Offensive Weapons Periods.

Experience with biological research laboratories at ANL-E spans several decades; the Biosciences Division currently has BSL-1 and BSL-2 laboratories in operation. On the basis of information provided by the ESH Coordinator of the Biosciences Division (Essling 2002a-c), no exposure or infection associated with its laboratory operations was reported in the past 10 years. Although ANL-E does not currently operate a BSL-3 laboratory, ANL-E has the expertise to evaluate and inspect the BioCARS BSL-3 facility and to make suggestions to improve the SOP. This expertise, along with the fact that the experiments would be conducted by experienced BSL-3 workers, would ensure that the BSL-3 facilities would be operated safely and that potential impacts to human health and the environment would be controlled and minimized. 


\section{Off-Normal Conditions}

The potential for laboratory-acquired infection is considered an accident because of the low frequency of exposures. According to the CDC (1999), because control of infection in laboratories has achieved such a high level of sophistication and because of common acceptance of standard laboratory practices, laboratory-acquired infections are expected to be virtually nonexistent today. The CDC statement is supported by the compilation of microbial disease reports by Collins (2000), which shows that in the last 10 years, no laboratory-acquired infection was reported in the United States. The low risk numbers estimated by the DA in the final PEIS regarding the operations of its laboratories under the BDRP (see discussions in the Normal Conditions Section) further support the CDC statement.

Although the frequency of accidents is very low, they do still occur. The primary routes of exposure are through unintentional injections by sharps, dermal contact through a cut wound in the skin, and inhalation of aerosols generated by normal laboratory equipment. The potential infection associated with such accidents could be reduced or stopped by prompt treatment with antibiotics, antiviral drugs, or other appropriate medical strategies.

Low-probability events that involve the generation of heat, fire, and wind could actually result in the microorganisms being killed. Consequently, some catastrophic events, such as earthquakes, fires, explosions, and airplane crashes, were viewed to have the potential of reducing the release of microorganisms. The low probability of such disastrous events, combined with the low probability of such an event's occurring during an activity when microorganism containment would be vulnerable, renders potential exposures through such events unlikely to occur.

An existing emergency power generator is available to provide power for the biosafety cabinets and the exhaust fans. The experimenters would be required to be present at all time when BSL-3 experiments were being conducted; thus, the risk of theft or sabotage would be very small.

\subsubsection{Enhanced Operations: Construction and Operation of the CNM Facility}

Physical injuries or even fatalities could occur during the construction of the proposed CNM facility. However, CNM construction injury rates are expected to be less than one-tenth that experienced by the general construction industry given the aggressive safety program in place at ANL-E. The current total injury rate in nonresidential building construction is 7.6 injuries per 100 workers per year. The total injury rate for contracted work at the APS during the past five years has been 0.0 (no lost-time injuries), during which more than $\$ 20$ million in contracted work has been completed.

Operation of the CNM would not involve modifications to the designs of the APS components (LINAC, synchrotron, and storage ring) and would not affect their operations. The Proposed Action would involve construction of new beamlines and LOMs that would be designed in accordance with the APS shielding policy so that individual radiation exposures 
would be maintained at about the current levels. However, because the Proposed Action would result in hiring additional workers and attracting more beamline users (according to Glagola [2002], the number of users projected for 2007 would be twice as many as that in 2001), collective exposures of these receptors would increase proportionally. Discussions on individual radiation exposures are provided in Section 5.1.8.1 under "Radiological Effects."

The CNM facility would support the research activities related to the study of material behavior at the nanoscale and include laboratories for fabricating and characterizing the materials. Depending on the proposed experiments by beamline users, a wide variety of chemicals and equipment would potentially be used in the study. In addition, some biological agents (BSL-1 or 2) would potentially be introduced. Appendix B provides more detailed discussions on the experimental activities associated with the CNM facility. The types of materials used in the CNM facility would potentially be diverse, and so would the types of potential hazards associated with their uses. The amount of materials used in the CNM facility would be small, thereby reducing the degree of potential hazards. The safety of human health associated with operations of the CNM facility would be ensured by (1) incorporating engineering designs into the new facilities to reduce the potential release of hazardous substances, (2) implementing the experiment safety review to identify potential hazards before conduct of the experiments and to incorporate safety measures into experiment designs, and (3) providing safety training courses to the beamline users and implementing the requirement to conform with the established safe handling procedures during the conduct of experiments to reduce the occurrence of accidents. Potential routes of human exposure to hazardous substances are inhalation, ingestion, and dermal absorption, as discussed in Section 5.1.8.1 under "Nonradiological Effects." Therefore, the effectiveness of reducing human health risks through engineering designs, experimental safety review, and material safe handling procedures provided in that section are also applicable to the CNM facility.

On the basis of the discussions in Section 5.1.8.1, potential human health impacts associated with CNM operations would be negligible.

\subsubsection{Waste Management}

In accordance with standard procedures at the BioCARS facility, all liquid waste from BSL-3 level research would be decontaminated before collection, shipment, and disposition through the ANL-E waste management program (ANL 2000). All solid biohazardous wastes would also be decontaminated before management and shipment for further off-site treatment and disposition. Depending on the chemical components in the wastes and the chemical components used for disinfection, the resulting waste may be classified as hazardous due to chemical composition and would require management as such. Biological wastes generated at the CNM would be similarly managed. Operation of the BSL-3 facility and the CNM would not generate any waste required to be managed as medical waste under Illinois medical waste regulations. 
Additional activities at the CNM would result in an increase in waste generation from the APS. While waste quantities and waste types are not known, the types of work carried out are similar to the types of work carried out in other areas of the APS and the ANL-E site and would be handled by ANL-E WMO. Wastes can be expected to be generated in relatively small volumes (e.g., grams, liters, or gallons per month), and existing waste management capacities at ANL-E can be expected to easily absorb increases to ANL-E waste volumes from CNM-related activities (see Table 5.4).

\subsubsection{Transportation}

No upgrades to transportation or transportation networks are required for continued operation of the APS facility. Materials used in BSL-3 research activities would be transported in accordance with all applicable regulations. A maximum of a 5\% increase in traffic could occur if the CNM office space reaches maximum capacity of 150 people at one time (60 regular staff and up to 90 new off-site users). The majority of waste generated at APS can be combined with regular ANL-E waste shipments. However, BSL-3 wastes (estimated on the order of mg and mL quantities per year) would be transported separately (as indicated in Section 5.1.9 and Appendix A).

Parking spaces now occupying areas included in the footprint of new facilities would be replaced. Construction of the CNM facility would not interfere with the transportation requirements of other ANL-E workers or of local area residents. Construction traffic would access the APS site from existing entrances to the site. Temporary congestion at entrance gates may be experienced. All roads are adequate for transportation of both workforce and materials. Truck transport of bulk materials for construction at the APS site would not impact local area residents accessing their homes from Lemont Road, since this roadway is already used heavily for materials transport.

TABLE 5.4 Projected Hazardous Waste, Radiological Waste, and Wastewater Generated Annually by ANL-E and the APS under the Proposed Action

\begin{tabular}{lccc}
\hline \multicolumn{1}{c}{ Waste Category } & $\begin{array}{c}\text { Projected } \\
\text { ANL-E Quantity } \\
(\mathrm{gal})\end{array}$ & $\begin{array}{c}\text { Projected } \\
\text { APS Quantity } \\
\text { (gal) }\end{array}$ & $\begin{array}{c}\text { Increase } \\
\text { above Existing } \\
\text { Levels (gal) }\end{array}$ \\
\hline RCRA hazardous waste & 11,248 & 1,711 & 1,200 \\
HSWA universal hazardous waste & 13,682 & 50 & 10 \\
Low-level radioactive waste & 31,933 & 5.25 & 0.25 \\
Wastewater & 321.6 million & 57.2 million & 0.350 million \\
\hline
\end{tabular}




\subsubsection{Utilities and Services}

No major changes in utilities services would be required for construction and operation of the CNM. The APS currently consumes approximately $25 \mathrm{MW}$ of power annually. The current CNM design would draw another 3.5 MW. ANL-E, including the APS, implements energy conservation measures during times of high electricity demand.

\subsubsection{Environmental Justice}

For two reasons, no disproportionately high and adverse human health or environmental impacts to minority and low-income populations are anticipated under the Proposed Action during continued APS operation, construction of the proposed CNM, or operation of the CNM. First, none of the impacts of operations of the APS or proposed enhancements would have high or adverse health or environmental impacts. The impacts of the Proposed Action are limited to within site boundaries or uninhabited areas close to the ANL-E southern boundary. Second, the populations immediately surrounding the ANL-E site cannot be considered minority or lowincome, on the basis of national and Illinois thresholds for minority and low-income populations (see Section 4.13). While the greater Chicago area, within $50 \mathrm{mi}(80 \mathrm{~km})$ of ANL-E is ethnically and racially diverse, with areas with a high proportion of minority peoples, these areas would not be adversely affected by APS operations.

\subsection{EFFECTS OF NO ACTION}

The No-Action Alternative is the continued operation of the APS without enhanced operations, such as the construction and operation of the CNM, and without BSL-3 research at BioCARS. This section summarizes the conclusions regarding the environmental impacts of continued operation contained in Section 5.1.

Soil erosion at the APS site is controlled on this relatively flat area by landscaping, lawn maintenance, and limiting transportation to paved roadways and parking lots. Continued operation of the APS facility has little impact on soils due to erosion.

The APS facility does not include sanitary or laboratory wastewater treatment facilities; these liquid wastes are collected, treated, and discharged by ANL-E (see Section 4.3, Cumulative Impacts). Surface water quality in streams and wetlands adjacent to the APS facility is maintained by detention basins that remove sediments from site runoff. Impacts from sediments on local area streams during continued APS operations would be minor. Continued operation of the APS would not impact groundwater. Activation of groundwater from APS operations is not expected, because of the configuration of the APS.

Under the No-Action Alternative, criteria air pollutant emissions from the APS would remain less than $1 \%$ of total ANL-E releases. The APS would continue to have no impacts on adjacent areas from the noise of operations. 
Continued operation of the APS would be consistent with existing land use at ANL-E. Recreational and aesthetic qualities of adjacent areas of the Waterfall Glen Forest Preserve would not change from current conditions.

Impacts to ecological resources from operation of the APS facility under the No-Action Alternative would be similar to those for continued operations. Habitat disturbance and management activities on the APS site would not change from past disturbance levels. Wildlife would continue to avoid areas of human activity and would continue to be disturbed by vehicle use and noise sources. Therefore, operation of the APS facility under the No-Action Alternative would have negligible effects on terrestrial habitats, wildlife, wetlands, aquatic biota, and threatened and endangered species.

No impacts to cultural resources are anticipated as a result of continued operation of the APS.

The operations of the APS is an important part of ANL-E operations, which employ about 3,500 people and result in direct expenditures of about $\$ 500$ million.

Potential human health impacts for the No-Action Alternative are expected to be the same as those for the Proposed Action. In general, radiation exposures would be well below regulatory standards set to protect human health. The possibility for acquired-infection associated with operation of the BSL-1 and BSL-2 facilities is expected to be very small so that potential biological effect is characterized as minor. Chemical risks and physical injuries are expected to be limited to the laboratory workers or beamline users. The possibility of accidents is expected to be very small because of the implementation of safety measures. Detailed discussions on the potential human health impact are provided in Section 5.1.8.

Waste management activities would continue to meet all regulatory requirements. Pollution prevention and waste minimization practices would continue to reduce the amount of waste generated.

Transportation conditions and utility usage would remain the same under the No-Action Alternative.

No disproportionately high or adverse impacts to minority or low-income populations are expected because of continued operations of the APS facility under the No-Action Alternative, because when compared with state averages, no such populations occur in the immediate vicinity of ANL-E.

\subsection{CUMULATIVE EFFECTS OF THE PROPOSED ACTION}

Under the proposed action, the small increase in wastewater effluents discharged to the ANL-E sanitary and laboratory wastewater treatment plants, combined with other ANL-E effluents at Outfall 001, is expected to have little cumulative effect on the water quality and biota of Sawmill Creek and the Des Plaines River. Although outfall effluents occasionally exceed 
NPDES permit limits, the proposed action would not be expected to change overall surface water quality at the ANL-E site.

Criteria air pollutant releases from the APS under the proposed action would be very small. Because they represent a small portion of total ANL-E releases, cumulative impacts from air pollutant releases at the APS would be expected to be negligible. Noise generated by construction would be cumulative with noise from aircraft traffic, local road traffic, and the model airplane field in the Waterfall Glenn Forest Preserve adjacent to the APS site. Together this noise may be a temporary annoyance to other users of the forest preserve.

The Proposed Action would make a negligible contribution to cumulative effects on ecological resources at the ANL-E site. Habitat loss because of implementation of the Proposed Action would make a negligible contribution to overall habitat loss in the region from development. Planting of native species on the CNM site, combined with other landscaping with native vegetation at ANL-E, would result in greater biodiversity and habitat quality of developed areas of the site.

The APS facility is only one of many facilities at ANL-E that release airborne radioactive emissions or produce penetrating radiation as part of their operations. APS facility releases are a small fraction compared with the total emission from all ANL facilities. The maximum perimeter dose to a hypothetical off-site individual from APS emissions was estimated to be about $1.1 \%$ of the maximum perimeter dose from all ANL emissions. These doses are much lower than the $10 \mathrm{mrem} / \mathrm{yr}$ dose limit set for air emissions. The proposed action would not be expected to increase the dose to off-site individuals or exceed the dose limit when combined with other ANL-E emissions. 


\section{CONSULTATION LETTERS}

The correspondence reproduced in this chapter includes references to a new facility, the Center for Structural Genomics; that facility is no longer part of the proposed action. 


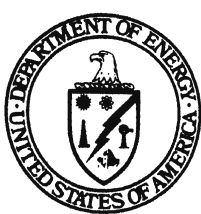

Ms. Anne E. Haaker, Deputy State Historic

Department of Energy

Argonne Area Office

9800 South Cass Avenue

Argonne, Illinois 60439

JAN 212003
MRED

JAN 2 2 2003

O301220010wDU

Preservation Services

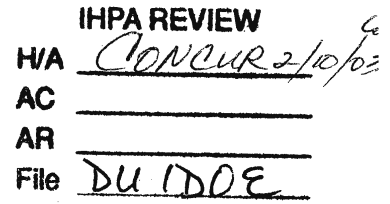

Illinois Historic Preservation Agency

Old State Capitol

Springfield, Illinois 62701

Dear Ms. Haaker:

The Department of Energy (DOE) is requesting your concurrence that proposed activities at Argonne National Laboratory would not affect structures or archaeological sites that are eligible for listing on the National Register of Historic Places.

DOE is preparing an Environmental Assessment (EA) for enhanced operations of the Advanced Photon Source (APS). The APS is a third generation synchrotron light source - a type of steady-state particle accelerator that provides high-brilliance beams of high-energy $x$-rays to a variety of scientists. The EA will address continued and enhanced operations of the APS. Continued operations would include existing types of research activities and upgrades to utility systems at the APS. Enhanced operations would include (1) construction and operation of a $40,000 \mathrm{ft}^{2}$ Center for Nanoscale Materials at the APS, (2) construction and operation of a $30,000 \mathrm{ft}^{2}$ Structural Genomic Center at the APS, and (3) biosafey level 3 research at the APS. Enclosure 1 shows the location of the APS at Argonne, and enclosure 2 shows the proposed new centers at the APS.

DOE does not believe these proposed activities would affect any eligible properties because the proposed new construction would be within the footprint of the area disturbed during construction of the APS in the early 1990's and because no structures at the APS are eligible for listing.

If you have any questions, please call Donna Green at (630) 252-2264.

Sincerely,

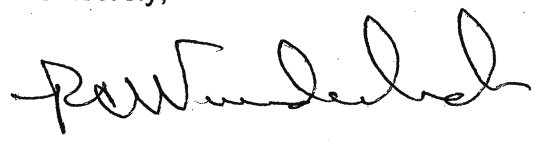

Robert C. Wunderlich Area Manager

Enclosures:

As Stated

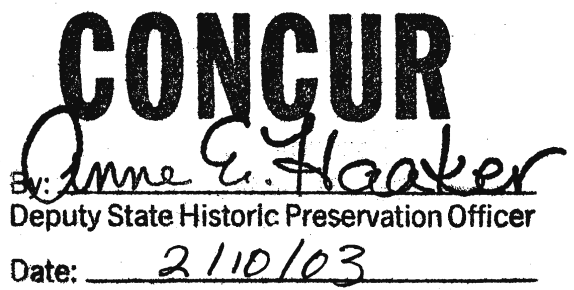

A component of the Chicago Operations Office 
Mr. John Rogner, Field Supervisor

U. S. Fish and Wildlife Service

Chicago Illinois Field Office

1250 South Grove Avenue, Suite 103

Barrington, Illinois 60010

Dear Mr. Rogner:

The Department of Energy (DOE) is requesting your concurrence that proposed activities at Argonne National Laboratory would not have adverse effects on Federally-listed threatened or endangered species.

DOE is preparing an Environmental Assessment (EA) for enhanced operations of the Advanced Photon Source (APS). The APS is a third generation synchrotron light source - a type of steady-state particle accelerator that provides high-brilliance beams of high-energy $X$-rays to a variety of scientists. The EA will address continued and enhanced operations of the APS. Continued operations would include existing types of research activities and upgrades to utility systems at the APS. Enhanced operations would include (1) construction and operation of a $40,000 \mathrm{ft}^{2}$ Center for Nanoscale Materials at the APS, (2) construction and operation of a 30,00 $\mathrm{ft}^{2}$ Structural Genomic Center at the APS, and (3) biosafey level 3 research at the APS. Enclosure 1 shows the location of the APS at Argonne, and enclosure 2 shows the proposed new centers at the APS.

DOE does not believe these proposed activities would adversely affect any Federally-listed species because we are not aware of any such species at the Argonne site and because the activities would not have ecological effects outside the site.

If you have any questions, please call Donna Green at (630) 252-2264.

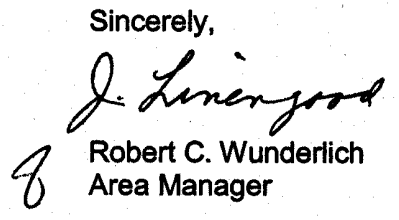

Enclosures:

As Stated

bc: w/encls.

G. Walach, GL

P. Siebach, STS

J. Houck, AAO

F. Gines, AAO

A. Cohen, ANL/EQO, 201

I. Lang, ANL/ASD, 401

E. Stull, ANL/EAD, 900

File: $5400.2(2.8)$ 


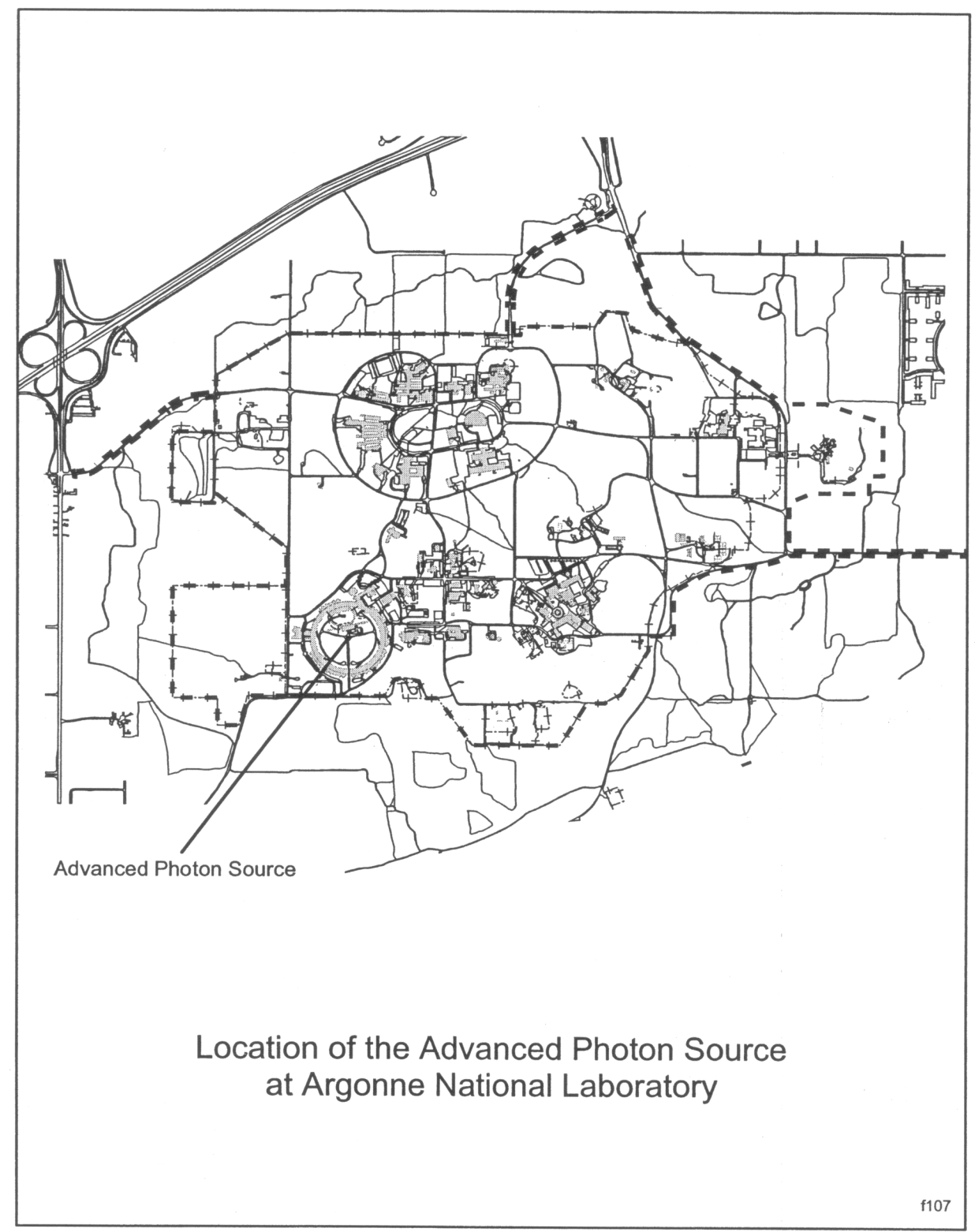




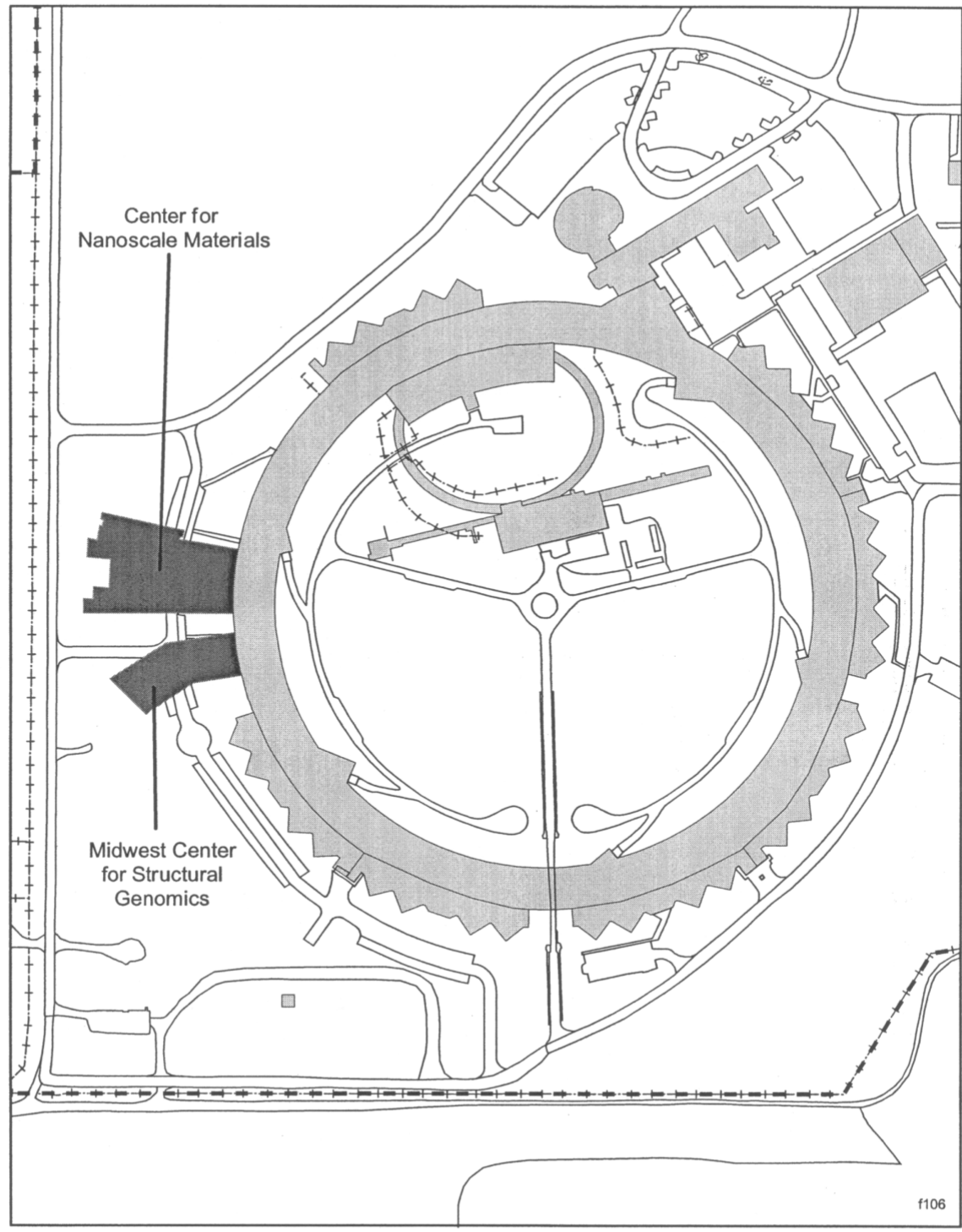

Planned Construction at the Advanced Photon Source 


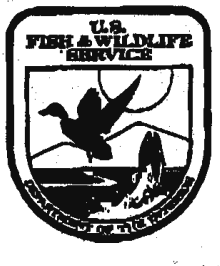

DN REPLY REFERR TO

\section{United States Department of the Interior}

U.S. FISH AND WILDLIFE SERVICE

Chicago Illinois Field Office

1250 South Grove Avenue, Suite 103

Barrington, Illinois 60010

847-381-2253 847-381-2285 (Fax)

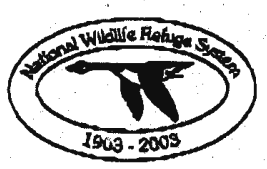

colebinting 4

Centuky

of Consonvation!

FWS/AES-CIFO

(T1372)

Augus: 27, 2002

Mr. Robert C. Wunderlich

Department of Energy

Argonne Area Office

9800 South Cass Avenue

Argonne, Illinois 60439

Dear Mr. Wunderlich:

This responds to your letter dated August 13, 2002 requesting information on endangened or threatened species on or near the site of the proposed enhanced operations of the Advariced. Photon Source located at T37N, R11E, Section 9 at Argonne National Laboratory, DuP'age County, Illinois as depicted on the map you enclosed.

The proposed site as depicted on your map is approximately 1 mile from a known habilit location for the federally endangered Hine's emerald dragonfly (Somatochlora hineana). The Hine's emerald dragonfly occupies marshes and sedge meadows fed by calcareous groundwater seepage and underlain by dolomite bedrock. In general, these areas are characterized by the presence of slowly flowing water and nearby or adjacent forest edges. Water quality and quantity is an important element of the Hine's emerald dragonfly habitat. Maintaining adequate water quality through surface and groundwater monitoring is essential since the species uses its aquatic habitat for breeding and spends the majority of its life cycle in an aquatic form. We request that studies be conducted in order to determine if the proposed project, could atversely affect the hlabitat of the Hine's emerald dragonfly. Studies should focus on determining if the proposed project is in the same aquifer as the aquifer that supplies groundwater to the Jijne's emerald dragonfly site and if the project would affect water quality or quantity. Waterisined-wide studies are currently underway coordinated by Corlands and the U.S. Amy Corps of Erigineers Chicago District. 
If the studies reveal that the project adversely affects water quality or quantity, consultation on this project should begin with the Service and the U.S. Army Corps of Engineers in accordance with section 7 of the Act.

This letter only addresses federally listed species; the Ilinois Department of Natural Resources should be contacted for information on State-listed species. Any impacts to wetlands or waters of the United States may require a permit from the U. S. Army Corps. of Engineers. This letter does not preclude separate evaluation and comment by the U.S. Fish and Wildlife Service on wetland impacts proposed for section 404, Clean Water Act authorization.

If you have any questions, please contact Ms. Cathy Pollack at 847/381-2253, ext. 239 or Ms. Karla Kramer at 847/381-2253, ext. 230.

Sincerely,
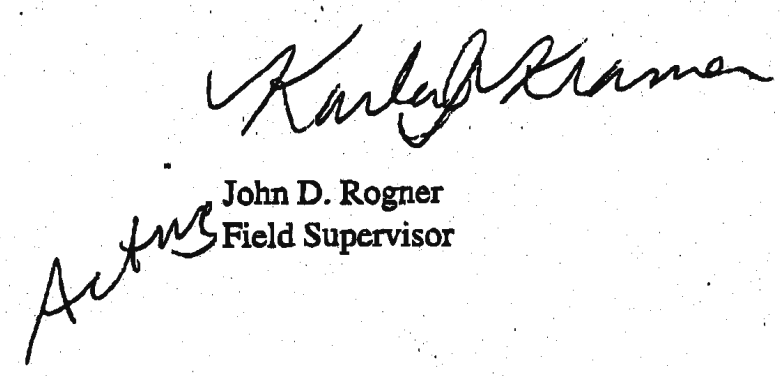
Mr. John Rogner, Field Supervisor

U. S. Fish and Wildife Service

Chicago Illinois Field Office

1250 South Grove Avenue, Suite 103

Barrington, Illinois 60010

Dear Mr. Rogner:

References: 1. Letter, R. Wunderlich to J. Rogner, dated August 13, 2002

2. Letter, J. Rogner to R. Wunderlich, dated August 27, 2002

On August 13, the Department of Energy requested your concurrence that continued operations of and proposed upgrades to the Advanced Photon Source (APS) at Argonne National Laboratory would not have adverse effects on Federally-listed threatened or endangered species. You responded on August 27 and asked for studies to determine if the proposed activities could adversely affect the Hine's emerald dragonfly habitat approximately one mile to the south of the APS.

We have evaluated the impacts of continued operations of the APS and upgrades to the APS and concluded that neither would adversely affect either the quantity or the quality of water in the aquifer that feeds the dragonfly habitat.

The dragonfly habitat is fed by the regional Silurian dolomite aquifer that is 150 to 200 feet thick in southeast DuPage County. At the APS, the dolomite is overlain by more than 100 feet of glacial drift material. Much of this drift is fine-grained low-permeability glacial till, with thin interbeds of discontinuous sands and gravels. Flow within the drift is predominantly lateral within the more permeable interbeds, with little or no connection to the dolomite aquifer.

The Argonne water supply is from Lake Michigan. Neither continued operations of the APS nor proposed upgrades to the APS would involve pumping water from the dolomite aquifer.

Wastewater from the APS would continue to be treated at the Argonne Wastewater Treatment Plants and discharged to Sawmill Creek; storm water would be managed to avoid impacts to surface waters.

Since the APS is a particle accelerator, it has a potential to create short-lived activation products such as oxygen-15 in soil and groundwater. However, activation products in the soil and groundwater at the APS are expected to remain negligible due to the configuration of the APS. Because there is very little connection between the glacial till aquifer that underlies the APS and the dolomite aquifer that feeds the dragonfly habitat, there would be no impacts on the dolomite aquifer from continued operations and upgrades of the APS. 
If you have any questions, please call Donna Green at (630) 252-2264.

Sincerely,

\section{signed by}

Robert C. Wunderlich

Area Manager 


\title{
United States Department of the Interior
}

\author{
FISH AND WILDLIFE SERVICE \\ Chicago Ecological Services Field Office \\ 1250 South Grove Avenue, Suite 103 \\ Barrington, Illinois 60010 \\ Phone: (847) 381-2253 Fax: (847) 381-2285
}

IN REPLY REFER TO:

FWS/AES-CIFO/T1372/T331

Mr. Robert C. Wunderlich

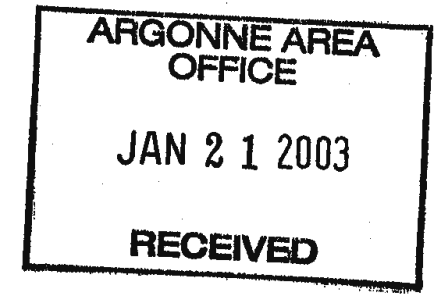

January 15,2003

Department of Energy

Argonne Area Office

9800 South Cass Avenue

Argonne, Illinois 60439

Dear Mr. Wunderlich:

Thank you for your response dated December 16,2002 in regards to a letter from us dated August 27, 2002 requesting searches for the federally endangered Hine's emerald dragonfly (Somatochlora hineana) at the proposed Argonne National Laboratory development site located at T37N, R11E, Section 9 at Argonne National Laboratory, DuPage County, Illinois as depicted on the map you enclosed.

We concur with the opinion of the Department of Energy, for reasons given, that the dragonfly is not likely to be present on the subject parcel.

Based on the information provided in your submittal and a review of our records, we do not believe that any federally endangered or threatened species occur in the vicinity of the site. Based on the information provided, it does not appear that the project is likely to adversely affect any federally threatened or endangered species or adversely modify critical habitat of such species. This precludes the need for consultation on this project in accordance with section 7 of the Endangered Species Act of 1973, as amended. Should project modifications or new information indicate that endangered or threatened species may be affected, and the project is funded, authorized or carried out by a Federal agency, then consultation with the Service should be initiated by the Federal action agency.

This letter only addresses federally listed species; the Illinois Department of Natural Resources should be contacted for information on State-listed species. Any impacts to wetlands or waters of the United States may require a permit from the U. S. Army Corps. of Engineers. This letter 
$6-12$

Mr. Robert C. Wunderlich

2

does not preclude separate evaluation and comment by the U.S. Fish and Wildlife Service on wetland impacts proposed for section 404, Clean Water Act authorization.

If you have any questions, please contact Ms. Kristy Mielcarek at 847/381-2253, ext. 227 or Ms. Karla Kramer at 847/381-2253, ext. 230.

Sincerely,

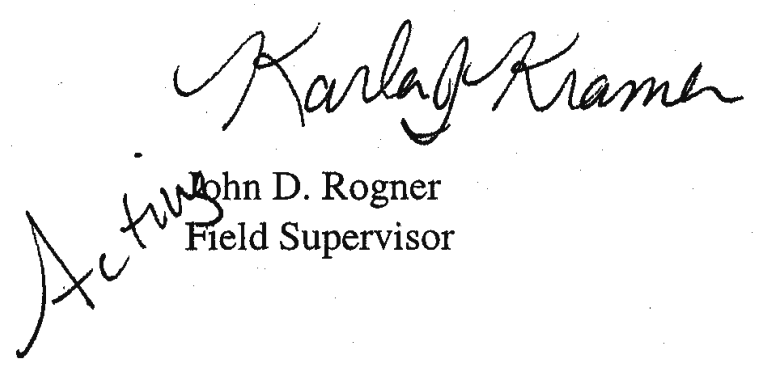




\section{REFERENCES}

Advanced Photon Source, 1998, Advanced Photon Source Safety Assessment Document, APS-3.1.2.1.0, Rev.1, prepared by Argonne National Laboratory for U.S. Department of Energy, Argonne, Ill., May.

Advanced Photon Source 2000, Standard Safety Envelopes for Experiment Activities at the Advance Photon Source, available at http://www.aps.anl.gov/xfd/safetyenvelopes/ safetyenvelopes.html, accessed Aug. 15, 2002.

Alvord, C.W., 1922, The Illinois Country 1673-1818, A.C. McClurg \& Co., Chicago, Ill.

ANL: See Argonne National Laboratory.

APS: See Advanced Photon Source.

Argonne National Laboratory, 2000, Waste Handling and Disposal at Argonne National Laboratory, Office of Public Affairs, Dec. 6, available at http://www.anl.gov/OPA/env/ WMfacts.html, accessed Aug. 7, 2002.

Argonne National Laboratory, 2002a, Office of Public Affairs Web Site, Argonne, Ill., available at http://www.anl.gov/OPA/photo/chimap3.gif, accessed Aug. 11, 2002.

Argonne National Laboratory, 2002b, Office of Public Affairs Web Site, Argonne, Ill., available at http://www.aps.anl.gov/ald/grafgal2/digital/photos/nrthaer15766.jpg; accessed Aug. 11, 2002.

Army: See U.S. Department of the Army.

BEA: See Bureau of Economic Analysis.

BIO: See Biosciences Division.

BioCARS, 2002, Web site at http://cars.uchicago.edu/biocars/index.html, accessed Aug. 7, 2002.

Bureau of Economic Analysis, 2002, "Regional Accounts Data, Local Area Personal Income," U.S. Department of Commerce, available at http://www.bea.gov/bea/regional/reis/action.cfm, accessed Aug. 14, 2002.

CDC: See Centers for Disease Control and Prevention.

Centers for Disease Control and Prevention, 1999, Biosafety in Microbiological and Biomedical Laboratories, U.S. Department of Health and Human Services, Public Health Service, CDC and National Institutes of Health (NIH), 4th Ed., Washington, D.C., April. 
Collins, C.H., 2000, "Laboratory- and Some Other Occupationally-Acquired Microbial Diseases: A Bibliography," available at http://www.boku.ac.at/iam/efb/lai.htm.

Curtis, S.A., and A. Berlin, 1980, unpublished information, Argonne National Laboratory, Argonne, Ill.

DOE: See U.S. Department of Energy.

Dolecek, E., 2002, personal communication from Dolecek (Environment, Safety, and Health Division, Argonne National Laboratory, Argonne, Ill.) to J.-J. Cheng (Environmental Assessment Division, Argonne National Laboratory, Argonne, Ill.), July 8.

EPA: See U.S. Environmental Protection Agency.

Essling, M.A., 2002a, "Status of Pathogenic Organism Investigation," attachment to facsimile transmittal from Essling (Biosciences Division, Argonne National Laboratory, Argonne, Ill.) to Cheng, J.-J. (Environmental Assessment Division, Argonne National Laboratory, Argonne, Ill.), Aug. 8.

Essling, M.A., 2002b, "Conducting Inventories of Biosafety Level 2 Infectious Materials," attachment to facsimile transmittal from Essling (Biosciences Division, Argonne National Laboratory, Argonne, Ill.) to Cheng, J.-J. (Environmental Assessment Division, Argonne National Laboratory, Argonne, Ill.), Aug. 8.

Essling, M.A., 2002c, "Resumption of Normal Activities after Pathogenic Organism Investigation," attachment to facsimile transmittal from Essling (Biosciences Division, Argonne National Laboratory, Argonne, Ill.) to Cheng, J.-J. (Environmental Assessment Division, Argonne National Laboratory, Argonne, Ill.), Aug. 8.

Federal Emergency Management Agency, 1982, Flood Insurance Rate Map, Community Panel Number 1701970065 B, DuPage County, Ill.

FEMA: See Federal Emergency Management Agency.

Glagola, B., 2002, personal communication from Glagola (Advanced Photon Source Operations Division, Argonne National Laboratory, Argonne, Ill.) to K. Wescott (Environmental Assessment Division, Argonne National Laboratory, Argonne, Ill.), June.

Golchert, N.W., and R.G. Kolzow, 2002, Argonne National Laboratory-East Site Environmental Report for Calendar Year 2001, ANL-02/2, Argonne National Laboratory, Argonne, Ill., Sept.

Golchert, N.W., et al., 2001, Argonne National Laboratory-East Site Environmental Report for Calendar Year 2000, ANL-01/2, Argonne National Laboratory, Argonne, Ill., Sept.

Hughes, G.M., et al., 1966, Bedrock Aquifers of Northeastern Illinois: Illinois State Geological Survey, Circular 406. 
Idaho Department of Environmental Quality, 2001, "Bioinfiltration Swale (Bioretention Swale)," BMP \#38b, in Catalog of Stormwater Best Management Practices for Idaho Cities and Counties, available at http://www.deq.state.id.us/water/stormwater_catalog/doc_bmp38b.asp, accessed May 2, 2003.

IDEQ: See Idaho Department of Environmental Quality.

IEPA: See Illinois Environmental Protection Agency.

Illinois Environmental Protection Agency, 2002, Illinois Annual Air Quality Report 2001, IEPA/BOA 02-015, Bureau of Air, Springfield, Ill., Aug.

Illinois Pollution Control Board, 1996, Title 35, Subtitle C, Chapter 1, Part 302, Subpart D: Secondary Contact and Indigenous Aquatic Life Standards, Section 302.407, Illinois Pollution Control Board, Springfield, Ill., May 24.

IPCB - see Illinois Pollution Control Board

Jones \& Stokes 2000, URBEMIS7G for Windows Computer Program User's Guide, Version 5.1.0, Sacramento, Calif., Oct., available at http://www.arb.ca.gov/planning/urbemis/ urbemis.htm.

Killey, M.M., and C.B. Trask, 1994, Geotechnical Site Investigation for an Advanced Photon Source at Argonne National Laboratory, Illinois, Illinois State Geological Survey, Environmental Geology Report 147.

Kottmeyer, N., 2003, "Proposed Argonne National Laboratory Project Wetland Impact Determination," memo from Kottmeyer (Principal Environmental Engineer) to J. Boyer (Wetland Specialist), DuPage County Department of Environmental Concerns, Wheaton, Ill., May 29.

KriStar, undated, A Summary of Tests of Flo-Gard ${ }^{\mathrm{TM}}$ and of Fossil Rock ${ }^{\mathrm{TM}}$, available at http://www.kristar.com/level2/info/infoAl.html, accessed April 30, 2003.

McNamee, D., 2003a, personal communication from McNamee (Waste Management Operations, Argonne National Laboratory, Argonne, Ill.) to R. Kolpa (Environmental Assessment Division, Argonne National Laboratory, Argonne, Ill.), Jan. 15.

McNamee, D., 2003b, personal communication from McNamee (Waste Management Operations, Argonne National Laboratory, Argonne, Ill.) to R. Kolpa (Environmental Assessment Division, Argonne National Laboratory, Argonne, Ill.), Jan. 15.

MDEQ: See Michigan Department of Environmental Quality.

Michigan Department of Environmental Quality, 2002, Rule 57 Water Quality Values, Surface Water Quality Assessment Section, Lansing, Mich., Nov. 25. 
Mitscherlich, E., and E.H. Marth, 1884, Microbial Survival in the Environment, Springer-Verlag, Berlin, Germany.

Moe, H.J., 1990, Advanced Photon Source: Radiological Design Considerations, APS-LS-141, Argonne National Laboratory, Argonne, Ill., January.

Moe, H.J., 1991, Advanced Photon Source: Radiological Design Considerations, APS-LS-141 Revised, Advanced Photon Source Division, Argonne National Laboratory, Argonne, Ill., July.

Moe, H.J., 1998, Radiological Considerations in the Operation of the Low-Energy Undulator Test Line (LEUTL), APS-LS-272, Argonne National Laboratory, Argonne, Ill., April.

National Council on Radiation Protection and Measurements, 1987, Ionizing Radiation Exposures of the Population of the United States, NCRP Report No. 93, Bethesda, Md.

NCRP: See National Council on Radiation Protection and Measurements.

Nelson, K., 2002, Use of a Constructed Reedbed Wetland in the Mitigation of Highway Runoff on the Ground-Water Quality in a Carbonate Rock Area, prepared for the Susquehanna River Basin Commission, in cooperation with the Pennsylvania Department of Transportation, Publication No. 219, Feb.

Quinn, J.J., et al., 2001, "Predicting the Effect of Deep-Rooted Hybrid Poplars on the Groundwater Flow System at a Phytoremediation Site," International Journal of Phytoremediation 3(1):41-60.

Richburg, J., et al., 2001, "Effects of Road Salt and Phragmites australis Invasion on the Vegetation of a Western Massachusetts Calcareous Lake-Basin Fen," Wetlands 21(2):247-255.

SMRC: See Stormwater Managers Resource Center.

Sonstrom, R., et al., 2002, "Treatment of Parking Lot Stormwater Using a Storm Treat System," Environmental Science and Technology 36(20):4441-4446.

Stormwater Managers Resource Center, 2002, "Stormwater Management Fact Sheet: Bioretention," available at http://www.stormwatercenter.net, site maintained by the Center for Watershed Protection, accessed Nov. 1, 2002.

Swanson, W.P., 1979, Radiological Safety Aspects of the Operation of Electron Linear Accelerators, Technical Report Series No. 188, International Atomic Energy Agency, Vienna, Austria.

Tanner, H.H., 1987, Atlas of Great Lakes Indian History, University of Oklahoma Press, Norman, Okla. 
Transportation Research Board, 1991, Highway Deicing: Comparing Salt and Calcium Magnesium Acetate: Special Report 235, National Research Council, Washington, D.C.

TRB: See Transportation Research Board.

Tuggle, B., 1996, letter from Tuggle (U.S. Fish and Wildlife Service, Chicago Field Office, Barrington, Ill.) to E. Dodd (Environment, Safety, and Health/Quality Assurance Oversight, Argonne National Laboratory, Argonne, Ill.), July 25.

University of Chicago, 2003, Cars Safety Plan, available at http://cars.uchicago.edu/safety/ Safety_current.pdf.

U.S. Department of the Army, 1989, U.S. Army Medical Research and Development Command (USAMRDC), Final Programmatic Environmental Impact Statement; Biological Defense Research Program, Fort Detrick, Frederick, Md., April.

U.S. Department of Energy, 1990, Environmental Assessment, Proposed 7-GeV Advanced Photon Source, DOE/EA-0389, Feb.

U.S. Department of Energy, 2001, Environmental Assessment for Proposed Wetlands Management on the Argonne National Laboratory-East Site, DOE/EA-1387, Sept.

U.S. Environmental Protection Agency, 1988, Ambient Water Quality Criteria for Chloride1988, EPA 440/5-88-001, Office of Water, Washington, D.C.

U.S. Environmental Protection Agency, 1990, Water Quality Standards for Wetlands, National Guidance, EPA 440/5-90-011, Office of Water, Regulations and Standards, Washington, D.C.

U.S. Environmental Protection Agency, 1999, Stormwater Technology Fact Sheet, Bioretention, EPA 832-F-99-012, Office of Water, Washington, D.C.

U.S. Environmental Protection Agency, 2000a, Ambient Water Quality Criteria Recommendations, Information Supporting the Development of State and Tribal Nutrient Criteria for Rivers and Streams in Nutrient Ecoregion VI, Office of Water, and Office of Science and Technology, Health and Ecological Criteria Division, Washington, D.C.

U.S. Environmental Protection Agency, 2000b, Low Impact Development (LID), a Literature Review, EPA 841-B-00-005, Office of Water.

U.S. Environmental Protection Agency, 2002, National Recommended Water Quality Criteria: 2002, EPA 822-R-02-047, Office of Water.

U.S. Environmental Protection Agency, 2003, National Emission Inventory (NEI) 1999 Final Version 2 for Criteria Pollutants, Office of Air Quality Planning and Standards, Research Triangle Park, N.C., Jan. 8, available at ftp://ftp.epa.gov. 
Van Lonkhuyzen, R.A., and K.E. LaGory, 1994, Wetlands of Argonne National Laboratory-East DuPage County, Illinois, ANL/EAD/TM-12, Environmental Assessment Division, Argonne National Laboratory, Argonne, Ill.

Walitschek, D., et al., 1988, unpublished information, Argonne National Laboratory, Ill.

Wescott, K., and D. O'Rourke, 2001, unpublished information, Argonne National Laboratory, Argonne, Ill., Sept.

Wilcox, D., 1986, "The Effects of Deicing Salts on Vegetation in Pinhook Bog, Indiana," Canadian Journal of Botany 64:865-874.

Willman, H.B., 1967, Geologic Map of Illinois, Illinois State Geological Survey, 1:500,000 scale map.

Winer, R., 2000, National Pollutant Removal Database for Stormwater Treatment Practices, 2nd Ed., Center for Watershed Protection, Ellicott City, Md.

Ziezel, A.J., et al., 1962, Ground-water Resources of DuPage County, Illinois, Illinois State Water Survey and Illinois State Geological Survey Cooperative Ground-Water Report 2. 


\section{GLOSSARY}

100-year floodplain: Lowlands bordering a river that would be flooded, on average, once in every 100 years.

Accelerator: A device (i.e., machine) used to produce high-energy, high-speed beams of charged particles, such as electrons, protons, or heavy ions, for research in high-energy and nuclear physics, synchrotron radiation research, medical therapies, and some industrial applications.

Activation: The process of making a radioisotope by bombarding a stable element with neutrons or protons. For example, when elements in air are exposed to radiation (irradiated), they can be changed into unstable isotopes (e.g., carbon-11, oxygen-15, nitrogen-13).

Activation product: A radionuclide produced by activation (see "activation," above).

Aquifer: A geologic formation that can yield significant quantities of groundwater to wells or springs.

Bench-scale studies: Very small-scale studies carried out in a laboratory, typically conducted prior to field-scale or pilot-scale studies.

Bending magnet: Bending magnets deflect the electrons in the accelerator into a circular path so that they follow a closed loop.

BioCARS: The structural biology group of the Consortium for Advanced Radiation Sources (managed by the University of Chicago Center for Advanced Radiation Sources), formed to foster frontier research in the field of macromolecular crystallography.

Biohazard: A hazard that is posed to humans by a biological organism, or by a material produced by such an organism.

Biosafety cabinet: A ventilated cabinet that is the primary containment device for operations involving biohazard materials.

Biosafety Level-3: Biosafety levels are specific combinations of work practices, safety equipment, and facilities that are designed to minimize the exposure of workers and the environment to infectious agents. Biosafety Level-3 applies to agents that may be transmitted by the respiratory route, which can cause serious infection. Biosafety levels are defined by the Centers for Disease Control and Prevention (CDC).

Bioswales: A vegetated catch basin or drainage channel that moves water as slowly as possible so that runoff is filtered by contact with vegetation and infiltration is maximized.

Biota: The living organisms in a given region. 
Blowdown water: Water removed from an evaporative system (e.g., cooling tower or boiler) to reduce mineral concentrations that can cause scaling.

Booster synchrotron: A piece of equipment that accelerates the electron beam to high energy before the beam is injected into the storage ring.

Chemical self-assembly: In chemical solutions, self-assembly (also called Brownian assembly) results from the random motion of molecules and the affinity of their binding sites for one another. Also refers to the joining of complementary surfaces in nanomolecular interaction.

Chillers: Cooling equipment

Cleanroom: A specially constructed enclosed area environmentally controlled with respect to at least one or more of the following parameters: particulate, temperature, humidity, air pressure, velocity and directionality of airflow, vibration, noise, viable particulate, and lighting.

Corrosives: Materials that cause visible destruction of, or irreversible alterations in, animal or human skin tissues at the site of contact.

Criteria air pollutants: Common air pollutants for which National Ambient Air Quality Standards have been established. They include sulfur dioxide, nitrogen oxides, carbon monoxide, ozone, particulate matter, and lead.

Cryogenic temperature: Producing, or related, to the production of extremely low temperatures.

Cumulative impacts: Potential impacts when the Proposed Action is added to other past, present, and reasonably foreseeable future actions.

de minimis: Certain quantities of pollutants that are legally defined as to be small enough to be exempt from environmental regulations.

Dermal absorption: Entry of a substance into the body through the skin.

Dolomite: Calcium magnesium carbonate, a common rock-forming mineral. Many rocks referred to as limestone are actually dolomite.

Effluent: A gas or fluid discharged into the environment. The term usually applies to wastewater discharged from a point source (such as a pipe) to surface waters.

Endangered Species: Any plant or animal species that is likely to become extinct within the foreseeable future throughout all or a significant portion of its range.

Exfoliating bark: Bark that peels off in thin layers.

Exotic: A species that is not native to a given area. 
Forb: Herbaceous plant other than those in the Gramineae (true grasses), Cyperaceae (sedges), and Juncaceae (rushes) families, that is, any nongrass-like plant having little or no woody material.

Fugitive emissions: Emissions (air pollutants) released to the air other than from stacks or vents. They are often due to equipment leaks, evaporative processes, and windblown disturbances.

Glacial till: Material (e.g., sand, pebbles, and boulders) deposited by a glacier.

Glaciation: The formation, movement, and recession of glaciers and ice sheets. Glaciation is a collective term describing all the geological processes associated with glacial activity.

Glacial drift: A load of rock material transported and deposited by a glacier. Glacial drift is usually deposited when the glacier begins to melt.

Glacial loading: Deformation of the earth's crust by the weight of glaciers.

Hazardous waste: According to the Resource Conservation and Recovery Act (RCRA), a waste that because of its characteristics may (1) cause or significantly contribute to an increase in serious irreversible illness, or (2) pose a substantial hazard to human health or the environment when improperly treated, stored, transported, disposed of, or otherwise managed. Hazardous waste possesses at least one of the following characteristics: ignitability, corrosivity, reactivity, or toxicity. Hazardous waste is not radioactive.

Hazardous material: Any substance capable of causing harm to people, animals, or the environment.

Heavy metal compound: A compound that contains heavy metals. Heavy metals are metallic elements of high molecular weight, such as mercury, chromium, cadmium, lead, and arsenic, that are toxic to plants and animals at known concentrations.

Herbaceous vegetation: Pertaining to plants with a nonwoody stem that die back in winter in the temperate zone.

High-throughput computational facility: A facility that delivers large amounts of computing capacity to its users over long periods of time by pooling available computing resources on the network.

Hydrologic: Pertaining to hydrology, the applied science concerned with the waters of the earth.

Indigenous: A species that occurs naturally in an area; native.

Infrastructure: The basic facilities, services, and utilities needed for the functions of an industrial facility or site. Transportation, water supply, and electrical systems are part of the infrastructure. 
Inhalation: Breathing. Material that is inhaled enters the lungs.

Insertion devices: Periodic arrays of magnet structures that are placed in the straight sections of the storage rings.

Invasive species: Native or non-native species that threaten ecosystems or habitats by displacing native species that are components of stable ecosystems or habitats.

Isostatic adjustments: Changes in land elevation caused by the buoyancy of the earth's crust (see also "glacial loading and unloading.")

Latent cancer: A cancer that becomes active following a latent period (i.e., a period of inactivity).

Linear acceleration/accelerator (LINAC): A long straight tube in which particles (mostly electrons or protons) are accelerated by electrostatic fields or electromagnetic waves and thus achieve very high energies.

Listed species: Species that are designated as threatened or endangered.

Lithography: In semiconductor science, it is a process used to transfer a pattern from a mask or reticule to a layer of resist deposited on a wafer.

Low-level radioactive waste: Waste that contains radioactivity and is not classified as high-level waste, transuranic waste, or spent nuclear fuel.

Low-level mixed waste: Waste that contains both hazardous and low-level radioactive waste.

Maximally exposed individual: A hypothetical person who because of proximity, activities, or living habits could receive the highest possible dose of radiation or of a hazardous chemical from a given event or process.

Maximum credible incidence: The most serious incident that could be expected from the range of hazards.

Metrology: The science of measurement.

Mitigation: A series of actions implemented to ensure that projected impacts will result in no net loss of habitat value or wildlife populations.

Nanoscale: 1 to 100 billionths of a meter.

Nanoscience: The extension of existing sciences into the nanoscale level.

Neutron: An uncharged elementary particle with a mass slightly greater than that of the proton, and found in the nucleus of every atom heavier than hydrogen. 
Nitrogen oxides $\left(\mathrm{NO}_{x}\right)$ : The oxides of nitrogen, primarily nitrogen oxide and nitrogen dioxide, that are produced in the combustion of fossil fuels. Nitrogen oxides are criteria air pollutants.

Off-normal conditions: Abnormal or unplanned events or conditions.

Old field: An area that was formerly cultivated or grazed and where woody vegetation has begun to invade.

Order of magnitude: An amount equal to ten times a given value. If some quantity was ten times as great as another quantity, it would be an order of magnitude greater; if one hundred times as great, it would be larger by two orders of magnitude.

Outfall: The discharge point of a drain, sewer, or pipe into a body of water.

Oxidizers: Substances that give up oxygen readily to stimulate the combustion of organic matter.

Particulate matter: Fine liquid or solid particles, such as dust, smoke, mist, or fumes, found in air emissions. The size of the particulates is measured in micrometers (0.000039 inch). $\mathrm{PM}_{10}$ (particulate matter with an aerodynamic diameter equal to or less than 10 micrometers) and $\mathrm{PM}_{2.5}$ (particulate matter with an aerodynamic diameter equal to or less than 2.5 micrometers) are criteria air pollutants.

Particulates: Liquid or solid particles, such as dust, soot, mist, or smog, that are small enough to become airborne.

Penetrating radiation: Radiation that is able to penetrate many materials, including the human body. Gamma rays, beta particles, and neutrons are types of penetrating radiation.

Photons: A particle of light. The name given to a small bundle or quantum of electromagnetic energy.

Radionuclide: A radioactive atom or atoms.

Reactives: Materials that have a tendency to undergo chemical reaction with the release of energy. Undesirable effects, such as pressure buildup, temperature increase, or formation of toxic by-products may occur, because of the reactivity of a substance to heating, burning, direct contact with other material, or other conditions found in use or in storage.

Riparian: Relating to, living in, or located on the bank of a river, lake, or tidewater.

Sedges: Perennial nonwoody plants common to most freshwater. Sedges resemble grasses.

Sedimentation: The removal, transport, and deposition of sediment particles by wind or water.

Seismic: Pertaining to any earth vibration, especially that of an earthquake. 
Select Agents: Biological agents of human disease whose transfer or receipt requires a facility to be registered with the CDC under 42 CFR Part 72.6. Select agents have historically been associated with weapons production efforts and thereby require a heightened level of security.

Silt: A sedimentary material consisting of fine mineral particles intermediate in size between sand and clay.

Skyshine: Ionizing radiation that escapes skyward through roof shielding and reflects or shines back toward the ground some distance from the source.

Storage ring: A device, associated with an accelerator, that stores the accelerated electrons in a circular orbit at a particular speed. To achieve nuclear reaction, the electrons are directed against particle groups orbiting in the reverse direction.

Synchrotron: A machine that accelerates and guides charged particles, such as electrons, into an orbit. As the electrons round each bend in the accelerator ring, they are guided by powerful magnets and give off energy in the form of light. This is called "synchrotron light."

Synchrotron radiation/synchrotron light: The radiation emitted by charged particles being accelerated in magnetic fields and moving at speeds near that of light. Synchrotron radiation is another term for synchrotron light, the broad spectrum of light produced by a synchrotron. It ranges from infrared light to visible light, to X-rays.

Tectonic: Concerning changes in the structure of the earth's crust or the forces that cause such changes.

Terrestrial: Living or growing on land rather than in water or air.

Threatened species: Any plant or animal species that is likely to become an endangered species within the foreseeable future throughout all or a significant portion of its range.

Transformer: A device that transfers electrical energy from one electric circuit to another, without changing the frequency. The energy transfer usually takes place with a change of voltage.

Transuranic waste (TRUW): Radioactive waste that contains more than 100 nanocuries per gram of alpha-emitting isotopes with atomic numbers greater than 92 and half-lives greater than 20 years.

Undulator: A device that moves the beam of light in the storage ring by about a micrometer.

Wet chemical processing: Laboratory procedures that use liquid chemical solutions (wet) rather than, or in addition to, laboratory instruments.

Wetland seeps: In wetlands, seeps are land that oozes water. 
$X$-ray: A high-energy electromagnetic radiation. It has a wavelength between 0.01 and 100 nanometers, which is between gamma rays and ultraviolet light, and can penetrate solids and ionized gas. 
APPENDIX A:

ACTIVITIES AND IMPACTING FACTORS ASSOCIATED WITH THE PROPOSED BIOLOGICAL SAFETY LEVEL-3 FACILITY 
A-2 


\section{APPENDIX A:}

\section{ACTIVITIES AND IMPACTING FACTORS ASSOCIATED WITH THE PROPOSED BIOLOGICAL SAFETY LEVEL-3 FACILITY}

The Consortium for Advanced Radiation Sources (BioCARS) Biological Safety Level-3 (BSL-3) Facility is the National User Facility for Macromolecular Crystallography, where users from universities nationwide can safely conduct $\mathrm{x}$-ray diffraction experiments on crystals of BSL-2 and BSL-3 agents. All experiments conducted at BioCARS are reviewed to ensure that the proper safety protocols are in effect. ${ }^{1}$ Table A.1 gives the definitions of the four biosafety levels defined by the Centers for Disease Control and Prevention (CDC). Agents classified as BSL-2 involve a broad range of indigenous, moderate-risk agents that are present in the community and associated with human disease of varying severity. Agents classified as BSL-3 are indigenous or exotic agents associated with serious and potentially lethal human diseases as a result of exposure by the inhalation route. The infection does not spread easily to others, however, and preventive or therapeutic intervention is available (high individual risk but low community risk). Examples of the microorganisms assigned to this level include Mycobacterium tuberculosis, St. Louis encephalitis virus, and Coxiella burnetii. Which particular BSL-3 agents will be used at the BioCARS facility will depend on the scientific proposals of principal investigators conducting experiments at BioCARS. The quantities of the agents to be used at any time at the BioCARS facility are small and typically involve a total of tens of crystals, with the volume of each crystal typically $\leq 10 \mathrm{~nL}\left(\leq 0.2 \mathrm{~mm}^{3}\right)$. Crystals are typically prepared at the user's home institution (itself a BSL-3 facility) and sent in accordance with U.S. Department of Transportation (DOT) regulations to the BioCARS facility, at most several days prior to the experiment. In some cases, it is necessary to prepare crystals at the BioCARS facility, in which cases a small amount of the agent solution is sent $(\leq 1 \mathrm{~mL}, \leq 10 \mathrm{mM})$.

In addition to the above categorizations, "The Antiterrorism and Effective Death Penalty Act of 1996" called for the definition of select agents that pose a severe threat to human health and safety and the regulation of the transfer thereof. Select agents were defined by the CDC in Title 42, Part 72, of the Code of Federal Regulations (42 CFR 72), Appendix A. Laboratories seeking to conduct research involving select agents must be registered with the CDC and undergo periodic CDC oversight audits. The currently proposed BSL-3 research agenda does not include the study of select agents. Thus, there are no immediate plans to seek CDC registration for the BSL-3 facility. However, it is possible that studies involving select agents will be proposed for the future. If decisions are made to accept research involving select agents into the BSL-3 facility, then CDC registration will be pursued. It is believed that the current engineering design of the BSL-3 facility will not require modification or enhancement in order to secure $\mathrm{CDC}$ registration.

1 Centers for Disease Control and Prevention (CDC) guidance is available at its Web site: http://www.cdc.gov/od/ ohs/biosfty/bmbl4/bmbl4toc.htm. 
TABLE A.1 CDC Definitions of Biosafety Levels

\begin{tabular}{|c|c|c|}
\hline Level & Description & Precautions \\
\hline BSL-1: & $\begin{array}{l}\text { "...viable microorganisms not known to } \\
\text { consistently cause disease in healthy } \\
\text { adult humans." } \\
\text { Examples: Bacillus subtilis, Naegleria } \\
\text { gruberi, and infectious canine hepatitis } \\
\text { virus. }\end{array}$ & $\begin{array}{l}\text {... standard microbiological practices } \\
\text { with no special primary or secondary } \\
\text { barriers recommended, other than a sink } \\
\text { for handwashing. }\end{array}$ \\
\hline BSL-2: & $\begin{array}{l}\text { "...broad spectrum of indigenous } \\
\text { moderate-risk agents that are present in } \\
\text { the community and associated with } \\
\text { human disease of varying severity." } \\
\text { Examples: Hepatitis B virus, the } \\
\text { salmonellae, and human-derived blood. }\end{array}$ & $\begin{array}{l}\text {...primary barriers should be used as } \\
\text { appropriate, such as splash shields, face } \\
\text { protection, gowns, and gloves. } \\
\text { Secondary barriers such as handwashing } \\
\text { sinks and waste decontamination } \\
\text { facilities must be available... }\end{array}$ \\
\hline BSL-3: & $\begin{array}{l}\text { "...indigenous or exotic agents with a } \\
\text { serious and potentially lethal infection." } \\
\text { Examples: Mycobacterium tuberculosis, } \\
\text { St. Louis encephalitis virus, and } \\
\text { Coxiella burnetii. }\end{array}$ & $\begin{array}{l}\text { All laboratory manipulations should be } \\
\text { performed in a Biological Safety } \\
\text { Cabinet (BSC) or other enclosed } \\
\text { equipment... Secondary barriers for this } \\
\text { level include controlled access to the } \\
\text { laboratory and ventilation requirements } \\
\text { that minimize the release of infectious } \\
\text { aerosols from the laboratory. }\end{array}$ \\
\hline $\begin{array}{l}\text { BSL-4 } \\
\text { (Included for } \\
\text { completeness. } \\
\text { Work at this } \\
\text { level is NOT } \\
\text { proposed) }\end{array}$ & $\begin{array}{l}\text { "...dangerous and exotic agents that } \\
\text { pose a high individual risk of life- } \\
\text { threatening disease, which may be } \\
\text { transmitted via the aerosol route and for } \\
\text { which there is no available vaccine or } \\
\text { therapy." Examples: Marburg virus and } \\
\text { Congo-Crimean hemorrhagic fever } \\
\text { virus. }\end{array}$ & $\begin{array}{l}\text {...Class III BSC or in a full-body, air } \\
\text { supplied positive-pressure personnel } \\
\text { suit. The BSL- } 4 \text { facility itself is } \\
\text { generally a separate building or } \\
\text { completely isolated zone with complex, } \\
\text { specialized ventilation requirements and } \\
\text { waste management systems to prevent } \\
\text { release of viable agents to the } \\
\text { environment. }\end{array}$ \\
\hline
\end{tabular}

Source: Available at CDC Web site: http://www.cdc.gov/od/ohs/biosfty/bmbl4/bmbl4toc.htm. 
Research at the BioCARS facility is, for the most part, basic research. Some proprietary research is conducted though, mainly to understand the interaction between drugs and their target proteins. The techniques of genetic engineering are used, along with other standard microbiological techniques, at the home institutions of the experimenters to produce samples for study at BioCARS. The facilities at BioCARS are not appropriate for the production of genetically engineered organisms.

Consistent with the normal operation of BioCARS, biological materials would be cultured at the home institution of the principal investigator. After the biological materials are cultured and purified, the process determining the optimal conditions for crystal growth commences. Proposals for beamtime at BioCARS usually do not take place before crystals have been obtained. Often the crystals can be frozen in liquid nitrogen and shipped by commercial carrier in accordance with U.S. Department of Transportation (DOT) regulations. Crystals that cannot, for whatever reason, be frozen, are shipped at room temperature or packed in dry ice. Occasionally crystals can be obtained but are too fragile to be shipped by any means. In this case, the purified biological material is transported by the appropriate means, and crystallization is initiated at BioCARS. In every case, the experiments are designed to minimize the handling of the biological material. This is done not only to protect the environment from the biological material, but also to protect the biological material from contamination from the environment.

The standard and specific safety practices, the safety equipment (primary engineering barriers), and secondary barriers, such as administrative controls and standard operating procedures (SOPs) for work with the BSL-3 agents, are described in the CDC's "Biosafety in Microbiological and Biomedical Laboratories" guidelines (CDC 1999). The BioCARS implementation of these practices and engineering and administrative controls is described in the BioCARS BSL-3 SOP. ${ }^{2}$

The most important features of the facility involve the Class II, type B2 biological safety cabinet and the directional airflow, where the air from the facility is exhausted through the safety cabinet after high-efficiency particulate air (HEPA) filtering. HEPA filters remove $99.97 \%$ of particles in air with a diameter of $0.3 \mu \mathrm{m}$ or larger. All sample manipulations are conducted in the safety cabinet. A sample (single crystal) is then transferred in a safe manner to the experimental station where the experiment is conducted. All waste generated during sample manipulation is collected and sent to incineration upon completion of the experiment. Because of the small quantity of the agents used and the engineering and administrative controls (described in the BioCARS SOP), the risk of an environmental release of agents is very low.

2 The scope of the BioCARS SOP is comprehensive. In addition to addressing the health, safety, and environmental aspects of each experiment, the BioCARS SOP also addresses biological agent security issues, including chain-of-custody controls and packaging requirements for shipments, controls for researcher access to biological agents, engineering controls for access to biological agent storage areas, quality control features for all aspects of agent management (including disinfection), and training of personnel regarding appropriate safe handling practices and administrative controls. The BSL-3 SOP appears as Appendix T to the CARS Safety Plan. The CARS Safety Plan, which addresses all activities occurring within the facility, was first published in May 1995 and last revised in January 2003. It can be viewed at http://cars.uchicago.edu/safety/Safety_current.pdf. 
Individual experiments at BioCARS typically last two to three days. Currently, the facility supports an average of three experiments per year involving BSL-2 organisms. This level of activity is expected to continue into the foreseeable future. In addition, once the Proposed Action commences, the facility will support an expected two experiments per year involving BSL-3 organisms. However, the facility is now being operated at capacity. Therefore, to accommodate any new experiments involving BSL-3 agents, a proportional number of experiments (involving noninfectious biological agents) would be eliminated.

Chemicals used to support research on biological organisms are those commonly associated with microbiological research and are used in very limited quantities. For each experiment involving either BSL-2 or BSL-3 organisms, typical waste types and quantities include standard salt buffer solutions in milliliter quantities; wash solvents (typically $95 \%$ ethanol) in milliliter quantities; the sample itself (normally a single crystal of microgram proportion); and decontamination solutions (aqueous hypochlorite solutions) in milliliter quantities. For each experiment conducted at BioCARS, including those involving BSL-3 agents, the largest single volume waste will be personal protective equipment (PPE) (gloves, laboratory coats, etc.) and rags and wipes. A few cubic feet of such waste per experiment is typical. All wastes associated with BSL-3 organisms would be captured, disinfected, and delivered to the Waste Management Operations Division (WMO) of Argonne National Laboratory-East's (ANL-E's) Plant Facilities and Services (PFS) for subsequent delivery to an appropriately permitted commercial facility for incineration. Provisions are in place for currently generated BSL-2 wastes to be handled in the same manner. However, for some BSL-2 wastes, the individual researcher has the option of having all wastes and excess chemicals returned to his/her home institution. In those instances, ANL-E will provide support for such shipments. Each experiment is expected to generate small amounts of wastewater, primarily from the disinfection of experimental solutions. Wastewaters directly associated with experiments will be captured and removed from BioCARS for further treatment or off-site disposal, as appropriate. Other wastewaters associated with routine operation of the BioCARS facility include small amounts of detergent wash solutions from cleaning of experimental equipment and glassware and handwashing activities. Because there is no potential for agent contamination in such wash waters, they are currently discharged via the ANL-E industrial sewer system to the ANL-E industrial waste treatment facility. This management scheme would not change under the Proposed Action. The volumes and character of such wash solutions also would not change appreciably under the Proposed Action. Finally, solutions containing radioisotopes are prohibited from introduction into the BioCARS facility, and the process of conducting experiments using $\mathrm{x}$-ray beams cannot activate the samples. Consequently, no radioactive or mixed wastes are possible. $^{3}$

As noted previously, under the Proposed Action, because the facility is now operating at capacity, some ongoing experiments involving noninfectious biological organisms would cease in order to accommodate an equal number of experiments involving BSL-3 agents. However, this would result in very little overall change to impacts from the BioCARS facility. Impacts to ambient air from building ventilation and biosafety cabinet exhausts should not change. Waste

3 Some sealed radiological materials would be present as reference standards. However, no wastes would result from the presence or use of these materials. Appropriate controls have been established for all such materials. 
volumes from each typical BSL-2 or BSL-3 experiment are very small (on the order of milliliter to deciliter quantities of liquids, milligram to gram quantities of solids, as well as a few cubic feet of solid waste, such as PPE, rags, and wipes). Wastes from experiments involving noninfectious wastes are of the same types and general orders of magnitude. Consequently, overall, waste volumes can also be expected to undergo very little change from those presently generated once BSL-3 research begins. However, the character of the waste would change slightly, and, as described previously, separate management procedures for BSL-3-related wastes would be put into effect for experiments involving those agents. Management of BSL-3-related wastes in the manner described would represent only small increases to the overall amount of biological agent-related wastes already being delivered to WMO from this facility and would not exceed WMO's current waste handling capacity.

\section{REFERENCE FOR APPENDIX A}

Centers for Disease Control and Prevention, 1999, Biosafety in Microbiological and Biomedical Laboratories, U.S. Department of Health and Human Services, Public Health Service, CDC and National Institutes of Health (NIH), 4th Ed., Washington, D.C., April. 
APPENDIX B:

EXPERIMENTAL ACTIVITIES AND IMPACTING FACTORS ASSOCIATED WITH THE PROPOSED CENTER FOR NANOSCALE MATERIALS FACILITY 


$$
\text { B-2 }
$$




\section{APPENDIX B:}

\section{EXPERIMENTAL ACTIVITIES AND IMPACTING FACTORS ASSOCIATED WITH THE PROPOSED CENTER FOR NANOSCALE MATERIALS FACILITY}

A comprehensive treatise on the scientific case for the Center for Nanoscale Materials (CNM) was published by Argonne National Laboratory (ANL-E) in December $2000 .{ }^{1}$ This appendix provides a brief overview of the CNM mission, focusing on physical infrastructure, experimental activities, and anticipated worker and environmental impacts of the proposed CNM research facility.

The study of material behavior at the nanoscale (i.e., virtually at the molecular level) holds great promise for expanding our ability to understand and predict important behaviors and properties of a wide array of materials. The current universal interest and focus on nanoscience and nanotechnology is supported by the recent development of tools that enable the preparation, characterization, and manipulation of nanoscale materials. The primary mission of the CNM would be the identification, exploration, development, and refinement of the techniques for fabrication of new nanoscale materials and the further development of tools for the characterization and study of these materials. In addition, the CNM would provide a venue and state-of-the-art facility for collaboration and coordination of research in this rapidly growing field of study. The CNM would be available to researchers from other national laboratories, universities, and industry, and would ensure that the science is truly national in its scale and focus.

The infrastructure necessary to support these research objectives consists of five main components: (1) conventional laboratories, (2) fabrication facilities, (3) instruments for characterization, (4) high-throughput computational facilities, and (5) new x-ray beamlines. The new facility being proposed will house the laboratories, fabrication facilities, characterization instruments, and computational facilities. The juxtaposition of the proposed CNM facility with the existing Advanced Photon Source (APS) facility would provide the opportunity to employ the x-ray beam already being generated at the APS with only minor modification to existing APS facilities and operations. The salient CNM capability would be its ability to conduct all stages of research on nanoscale materials, from synthesis and patterning through metrology, compositional and structural determination, and physical phenomena characterization. The physical environment of the CNM would consist of cleanrooms, encompassing approximately 10,000 $\mathrm{ft}^{2}$, and laboratories for chemical and physical measurements, mathematical computations, and data analysis, also covering approximately $10,000 \mathrm{ft}^{2}$. The remainder of the facility, approximately $20,000 \mathrm{ft}^{2}$, would be devoted to offices, conference rooms, and various infrastructure support operations.

Design specifications for the CNM experimental areas would incorporate the engineering and administrative controls necessary for the safe application of the energy sources employed

1 J.M. Gibson, et. al., 2000, Scientific Case for a Center for Nanoscale Materials at Argonne National Laboratory, Argonne National Laboratory, Argonne, Ill., Dec. 8. 
and the safe handling of the chemicals that would be involved in various research activities, many of which display hazardous properties. These design features would provide for the protection of the experimenters and also preempt intolerable contamination of nanoscale samples. Although the scale at which experimental activities would be conducted suggests that the potential environmental and worker impacts would be relatively small, the control devices that are expected to be installed on the ventilation systems of the cleanrooms and chemical hoods in some of the fabrication laboratories would provide additional substantial mitigation of those impacts. High-efficiency particulate air (HEPA) filters would be installed to service processes that may produce hazardous particulates (e.g., chemical milling operations), while scrubbers would be installed for processes having the potential to release hazardous chemical vapors or aerosols (e.g., electroplating and corrosive etching operations). Although final performance specifications have not yet been established, it can be anticipated that ventilation control devices would be expected to have contaminant removal efficiencies of $99 \%$ or greater. Because of its proximity to the APS, the CNM would be able to take advantage of existing major infrastructure support elements. For example, the existing APS emergency power generator would be reconfigured to provide emergency power to the CNM as well. However, some additional infrastructure unique to the CNM would be constructed, including a 1-MW natural-gas-fired steam generator that would be used to maintain humidity at optimal levels within experimental areas.

Experimental activities at the CNM would include fabrication and patterning of nanoscale materials and their subsequent characterization using a variety of instruments. Techniques employed in fabrication and patterning can include conventional wet chemical organic and inorganic synthesis; many techniques already widely used in industry, including chemical vapor deposition, physical vapor deposition, electrophoresis, electrochemistry, and etching; and new technologies that would be developed as part of the research effort. Patterning capabilities within the CNM would include optical and high-resolution electron beam lithography; liquid metal and gas sourced focused ion beam milling; x-ray lithography (utilizing the APS beamline); reactive ion etching; ion milling and ion-beam etching; wet chemical etching; and various scanning probe techniques, including nanoscribing, tip-assisted deposition, tip-controlled oxidation, and electrochemical reactions.

A wide variety of chemicals would be required to support the research activities at the CNM. Some nanoscale fabrication, patterning, and characterization research is already ongoing at various ANL-E facilities. Table B.1 lists the types of chemicals routinely being used to support this research. The quantities displayed are amounts typically kept on hand at these research locations but could represent quantities consumed over months or years, depending on the particular application and level of activity. This chemical listing provides some general insight into the types of chemicals that are likely to be present in the CNM to support continued ANL-E research. Chemicals supporting CNM research by ANL-E personnel are expected to be procured from commercial vendors through existing ANL-E chemical supply paths and delivered to ANL-E by commercial carriers. However, because the CNM is envisioned to be a user facility, researchers from other institutions, who could represent the majority in a fully mature CNM operation, may propose the use of different chemicals in their research ventures. All experiments, 
TABLE B.1 Types of Chemicals Routinely Used to Support Nanoscale Research Activities

\begin{tabular}{|c|c|c|c|c|}
\hline Common Name & CAS No. & Hazard & $\begin{array}{l}\text { Physical } \\
\text { Form }\end{array}$ & Quantity \\
\hline 2-Methylbutane & 78-78-4 & Flammable liquid glass IA & Liquid & $4 \mathrm{~L}$ \\
\hline 3-Mercaptopropyltrimethoxysilane & & & Liquid & $1 \mathrm{~L}$ \\
\hline 3-Methacryloxypropyltrimethoxysilane & & & Liquid & $1 \mathrm{~L}$ \\
\hline Acetic acid, $100 \%$ & $64-19-7$ & $\begin{array}{l}\text { Acid, corrosive, combustible liquid } \\
\text { Class II, Unstable Class } 2\end{array}$ & Liquid & $16 \mathrm{~L}$ \\
\hline Acetone & $67-64-1$ & Flammable liquid Class IB & Liquid & $28 \mathrm{~L}$ \\
\hline Acetonitrile & $75-05-8$ & Flammable liquid Class IB, Toxic & Liquid & $4 \mathrm{~L}$ \\
\hline Acetylene & $74-86-2$ & Flammable gas & Gas & $145 \mathrm{scf}^{\mathrm{a}}$ \\
\hline Adhesion promoters (non-HMDS) & & Flammable liquid Class IB & Liquid & $2 \mathrm{~L}$ \\
\hline Akanes & & Flammable liquid Class IB & Liquid & $2 \mathrm{~L}$ \\
\hline Ammonia & $7664-41-7$ & Toxic, corrosive & Gas & $2,270 \mathrm{scf}$ \\
\hline Ammonium bifluoride & $12125-01-8$ & Corrosive, toxic & Liquid & $7.5 \mathrm{~kg}$ \\
\hline Ammonium cerium nitrate & & & Solid & $1 \mathrm{~kg}$ \\
\hline Ammonium fluoride $40 \%$ & & & Liquid & $16 \mathrm{~L}$ \\
\hline Ammonium hydroxide & $1336-21-6$ & Caustic, corrosive, toxic & Liquid & $2.5 \mathrm{~kg}$ \\
\hline Ammonium hydroxide $57 \%$ & $1336-21-6$ & Caustic, corrosive, toxic & Liquid & $7.5 \mathrm{~kg}$ \\
\hline Ammonium phosphate & & & Solid & $500 \mathrm{~g}$ \\
\hline Anisole & $100-66-3$ & Flammable liquid & Liquid & $8 \mathrm{~L}$ \\
\hline Argon - inert gas & $740-37-1$ & Asphyxiant & Gas & $5,040 \mathrm{scf}$ \\
\hline Aromatics & & Flammable liquid Class IB & Liquid & $4 \mathrm{~L}$ \\
\hline $\begin{array}{l}\text { Biochemicals, waste: DNA, proteins, } \\
\text { metal colloids, cells, soft materials }\end{array}$ & & & Other & $100 \mathrm{~g}$ \\
\hline Boron trichloride & $10294-34-5$ & Toxic, corrosive & Gas & $150 \mathrm{scf}$ \\
\hline Butoxyethoxyethanol & & & Liquid & $16 \mathrm{~L}$ \\
\hline Butyl acetate & $123-86-4$ & Flammable liquid Class IB & Liquid & $8 \mathrm{~L}$ \\
\hline Carbon dioxide & $124-38-9$ & Asphyxiant & Gas & $532 \mathrm{scf}$ \\
\hline Carbon tetrachloride & $56-23-5$ & Toxic, other health hazard & Liquid & $0.1 \mathrm{~L}=100 \mathrm{~g}$ \\
\hline Carbon tetrafluoride & $75-73-0$ & & Gas & $306 \mathrm{scf}$ \\
\hline Ceric sulfate & $13590-82-4$ & Oxidizer Class 2 & Solid & $100 \mathrm{~g}$ \\
\hline Chlorine & $7782-50-5$ & Toxic, corrosive & Gas & $807 \mathrm{scf}$ \\
\hline Chlorobenzene & $108-90-7$ & Flammable liquid Class IC & Liquid & $4 \mathrm{~L}$ \\
\hline Chlorodifluoromethane & & Asphyxiant & Gas & \\
\hline Chloropentafluoroethane & $75-16-3$ & Asphyxiant & Gas & $85 \mathrm{scf}$ \\
\hline $\begin{array}{l}\text { Cobalt electroplating solutions and } \\
\text { chemicals for analysis }\end{array}$ & & & Liquid & $20 \mathrm{~L}$ \\
\hline Copper electroplating and chemicals & & Strong acid & Liquid & \\
\hline Copper sulfate & 7758-98-7 & Toxic & Solid & $2.5 \mathrm{~kg}$ \\
\hline Cyclopentanone (SU-8 2000 thinner) & & & Liquid & $4 \mathrm{~L}$ \\
\hline Deposition sources & & & Solid & $2.5 \mathrm{~kg}$ \\
\hline Detergents & & & Liquid & $16 \mathrm{~L}$ \\
\hline Dichlorodifluoromethane & $56275-41-3$ & Halocarbon (R-12) & Gas & $94 \mathrm{scf}$ \\
\hline Dichloroethane & $107-06-2$ & Flammable liquid Class IB, Toxic & Liquid & $4 \mathrm{~L}$ \\
\hline
\end{tabular}


TABLE B.1 (Cont.)

\begin{tabular}{|c|c|c|c|c|}
\hline Common Name & CAS No. & Hazard & $\begin{array}{l}\text { Physical } \\
\text { Form }\end{array}$ & Quantity \\
\hline Dichloro silane & $4109-96-0$ & Flammable, toxic, corrosive & Gas & $1,138 \mathrm{scf}$ \\
\hline Diethyl ether & $112-34-5$ & Combustible liquid Class IIIB & Liquid & $1 \mathrm{~L}$ \\
\hline Diols & & Flammable liquid Class IB & Liquid & $2 \mathrm{~L}$ \\
\hline $\begin{array}{l}\text { Diphenylphosphinoethyl- } \\
\text { dimethylethoxysilane }\end{array}$ & & & Liquid & $1 \mathrm{~L}$ \\
\hline Diphenylphosphinoethyltriethoxysilane & & & Liquid & $1 \mathrm{~L}$ \\
\hline Ethane & $74-80-0$ & Flammable gas & Gas & $200 \mathrm{scf}$ \\
\hline Ethanolamine & & & Liquid & $16 \mathrm{~L}$ \\
\hline Ethyl alcohol, ethanol & $64-17-5$ & Flammable liquid Class IB & Liquid & $42 \mathrm{~L}$ \\
\hline Ethyl ether & $60-29-7$ & $\begin{array}{l}\text { Flammable liquid Class IA, } \\
\text { Unstable Class I }\end{array}$ & Liquid & $1 \mathrm{~L}$ \\
\hline Ethyl lactate & & & Liquid & $8 \mathrm{~L}$ \\
\hline Ethylenediamine & $107-15-3$ & $\begin{array}{l}\text { Corrosive, toxic, flammable liquid } \\
\text { Class IC }\end{array}$ & Liquid & $1 \mathrm{~L}$ \\
\hline Ferric chloride & & & Solid & $1 \mathrm{~kg}$ \\
\hline Ferric nitrate & & & Solid & $1 \mathrm{~kg}$ \\
\hline Fluorine, $5 \% \mathrm{~F}_{2}$ in $\mathrm{He}$ & $7782-41-4$ & Highly toxic, oxidizer & Gas & $159 \mathrm{scf}$ \\
\hline Formic acid, $88 \%$ & $64-18-6$ & $\begin{array}{l}\text { Acid, corrosive, combustible } \\
\text { liquid Class IIIA }\end{array}$ & Liquid & $3 \mathrm{~L}$ \\
\hline Gallium & $7440-55-3$ & Toxic, corrosive & Liquid & $10 \mathrm{~g}$ \\
\hline $\begin{array}{l}\text { Gold electroplating solutions and } \\
\text { chemicals for analysis }\end{array}$ & & Weak bases & Liquid & $4 \mathrm{~L}$ \\
\hline Helium - inert gas & $7440-59-7$ & Asphyxiant & Gas & $2,037 \mathrm{scf}$ \\
\hline Heptane & $142-82-5$ & Flammable liquid Class IB & Liquid & $4 \mathrm{~L}$ \\
\hline Hexachloroplatinic acid $8 \%$ & 26023-84-7 & Corrosive, toxic & Liquid & $12 \mathrm{~L}=26 \mathrm{lb}$ \\
\hline Hexamethyldisilazane & $999-97-3$ & $\begin{array}{l}\text { Flammable liquid Class IB, water } \\
\text { reactive Class 2, toxic }\end{array}$ & Liquid & $2 \mathrm{~L}$ \\
\hline Hexane & $110-54-3$ & Flammable liquid Class IB & Liquid & $4 \mathrm{~L}$ \\
\hline Hydrazine & $302-01-2$ & $\begin{array}{l}\text { Corrosive, highly toxic, } \\
\text { combustible Class II, unstable } \\
\text { Class I }\end{array}$ & Solid & $200 \mathrm{~g}$ \\
\hline Hydrazine monohydrate & $7803-57-8$ & $\begin{array}{l}\text { Corrosive, toxic, combustible } \\
\text { liquid Class IIIA }\end{array}$ & Liquid & $1 \mathrm{~L}$ \\
\hline Hydrochloric acid & $7647-01-0$ & Acid, corrosive, toxic & Liquid & $48 \mathrm{~L}$ \\
\hline Hydrofluoric Acid & $7664-39-3$ & Toxic, corrosive & Gas & $67 \mathrm{scf}$ \\
\hline Hydrogen & 1333-74-0 & Flammable gas & Gas & $3,096 \mathrm{scf}$ \\
\hline "Forming Gas" - 5\% $\mathrm{H}_{2}$ in $\mathrm{N}_{2}$ & $1333-74-0$ & Flammable gas & Gas & $516 \mathrm{scf}$ \\
\hline Hydrogen bromide & $10035-10-6$ & Toxic, corrosive, irritant & Gas & $48 \mathrm{scf}$ \\
\hline Hydrogen peroxide $30 \%-50 \%$ & $7722-84-1$ & $\begin{array}{l}\text { Acid, oxidizer Class 2, unstable } \\
\text { Class } 2\end{array}$ & Liquid & $6 \mathrm{~L}$ \\
\hline $\begin{array}{l}\text { Iodine } \\
\text { Isopropyl alcohol }\end{array}$ & $67-63-0$ & Flammable liquid Class IB & $\begin{array}{l}\text { Solid } \\
\text { Liquid }\end{array}$ & $\begin{array}{l}100 \mathrm{~g} \\
48 \mathrm{~L}\end{array}$ \\
\hline
\end{tabular}


TABLE B.1 (Cont.)

\begin{tabular}{|c|c|c|c|c|}
\hline Common Name & CAS No. & Hazard & $\begin{array}{l}\text { Physical } \\
\text { Form }\end{array}$ & Quantity \\
\hline Isopropyl alcohol, PMMA developer & $67-63-0$ & Flammable liquid Class IB & Liquid & $16 \mathrm{~L}$ \\
\hline KOH developer & & & Liquid & $4 \mathrm{~L}$ \\
\hline Krypton - inert gas & $7439-90-9$ & Asphyxiant & Gas & $70 \mathrm{scf}$ \\
\hline $\begin{array}{l}\text { Lead electroplating solutions and } \\
\text { chemicals for analysis }\end{array}$ & & & Liquid & $16 \mathrm{~L}$ \\
\hline Liquid nitrogen & $7727-37-9$ & Cryogenic liquid & Liquid & $300 \mathrm{~L}$ \\
\hline Magnesium & $7439-95-4$ & Flammable solid & Solid & $50 \mathrm{~g}$ \\
\hline Metalorganics & & Toxic, flammable Class IB & Liquid & $4 \mathrm{~L}$ \\
\hline Methane & $74-82-8$ & Flammable gas & Gas & $360 \mathrm{scf}$ \\
\hline Methyl alcohol & $67-56-1$ & Flammable liquid Class IB & Liquid & $40 \mathrm{~L}$ \\
\hline Methyl ethyl ketone & 78-93-3 & Flammable liquid Class IB & Liquid & $4 \mathrm{~L}$ \\
\hline MIBK (PMMA developer) & & Flammable liquid Class IB & Liquid & $16 \mathrm{~L}$ \\
\hline Morpholine & $110-91-8$ & $\begin{array}{l}\text { Corrosive, flammable liquid } \\
\text { Class IC, toxic }\end{array}$ & Liquid & $14 \mathrm{~L}$ \\
\hline n-Butyl alcohol & $71-36-3$ & Flammable liquid Class IC & Liquid & $4 \mathrm{~L}$ \\
\hline Neon & $7440-01-9$ & Asphyxiant & Gas & $35 \mathrm{scf}$ \\
\hline Nickel plating bath (nickel sulfate $36 \%$ ) & 7786-81-4 & Toxic & Liquid & $10 \mathrm{~L}$ \\
\hline Nitric acid & $7697-37-2$ & Acid, corrosive, oxidizer Class 2 & Liquid & $18 \mathrm{~L}$ \\
\hline Nitrogen - inert gas & $7727-37-9$ & & Gas & Plumbed $^{b}$ \\
\hline Nitrogen trifluoride & $10102-43-9$ & Toxic, oxidizer & Gas & $55 \mathrm{scf}$ \\
\hline Nitrous oxide & $10024-97-2$ & Oxidizer gas & Gas & $522 \mathrm{scf}$ \\
\hline Novalac resist (Shipley) & & & Liquid & $8 \mathrm{~L}$ \\
\hline Organic acids & & Corrosive, toxic & Liquid & $4 \mathrm{~L}$ \\
\hline Other organics & & Toxic, flammable liquid Class IA & Liquid & $4 \mathrm{~L}$ \\
\hline Oxygen & 7782-44-7 & Oxidizer & Gas & $5,392 \mathrm{scf}$ \\
\hline Ozone & & Cryogenic gas, oxidizer Class 4 & Liquid & \\
\hline Ozone & & Cryogenic gas, oxidizer Class 5 & Liquid & $0.1 \mathrm{~L}$ \\
\hline Pentane & $109-66-0$ & Flammable liquid Class IA & Liquid & $4 \mathrm{~L}$ \\
\hline Perchloric acid & & & Liquid & $4 \mathrm{~L}$ \\
\hline Perfluoropropane & 76-19-7 & & Gas & $60 \mathrm{scf}$ \\
\hline Petroleum ether & $\begin{array}{l}\text { Mixture, } \\
\text { Various }\end{array}$ & Flammable liquid Class IB & Liquid & $4 \mathrm{~L}$ \\
\hline Phosphoric acid & $7664-38-2$ & Acid, corrosive & Liquid & $16 \mathrm{~L}$ \\
\hline Phosphorus pentoxide & $1314-56-3$ & $\begin{array}{l}\text { Corrosive, water reactive } \\
\text { Class } 2\end{array}$ & Liquid & $2 \mathrm{~kg}$ \\
\hline \multicolumn{2}{|c|}{ Platinum electroplating solutions and chemicals } & Strong acid & Liquid & $4 \mathrm{~L}$ \\
\hline $\begin{array}{l}\text { PM acetate, photoresist (PMA solvated. } \\
\text { Novalac) }\end{array}$ & $\begin{array}{l}\text { PMA: } \\
108-65-6\end{array}$ & Combustible liquid Class II & Liquid & $32 \mathrm{~L}$ \\
\hline PMGI 101 developer & & & Liquid & $8 \mathrm{~L}$ \\
\hline PMGI SF6 (Microchem) & & & Liquid & $2 \mathrm{~L}$ \\
\hline PMMA in anisole (Microchem) & & & Liquid & $8 \mathrm{~L}$ \\
\hline
\end{tabular}




\begin{tabular}{|c|c|c|c|c|}
\hline Common Name & CAS No. & Hazard & $\begin{array}{l}\text { Physical } \\
\text { Form } \\
\end{array}$ & Quantity \\
\hline Polyamide-based photoresists & $26023-21-2$ & Flammable liquid Class IB & Liquid & $16 \mathrm{~L}$ \\
\hline Potassium & $7440-09-7$ & Pyrophoric, corrosive & Solid & $50 \mathrm{~g}$ \\
\hline Potassium hydroxide & $1310-58-3$ & Corrosive, toxic & Liquid & $7.5 \mathrm{~kg}$ \\
\hline Potassium iodide & 7681-11-0 & & Solid & $100 \mathrm{~g}$ \\
\hline Propane & $74-98-6$ & Flammable gas & Gas & $8 \mathrm{scf}$ \\
\hline Pt Tetrakis & & Toxic (PF3) & Gas & $258 \mathrm{scf}$ \\
\hline Pump oil & & Combustible liquid Class IIIb & Liquid & $24 \mathrm{~L}$ \\
\hline Pyridine & $110-86-1$ & Flammable liquid Class IB & Liquid & $1 \mathrm{~L}$ \\
\hline Quartz cleaner & & & Liquid & \\
\hline Remover PG (nMP) & & & Liquid & $16 \mathrm{~L}$ \\
\hline $\begin{array}{l}\text { Resist thinner (PGMEA, ethyl lactate, } \\
\text { ethyl acetate, Anisole) }\end{array}$ & & Combustible liquid Class II & Liquid & $32 \mathrm{~L}$ \\
\hline Salts & & Corrosive, toxic & Solid & $1,000 \mathrm{~g}$ \\
\hline Scrubbers & & & Liquid & \\
\hline Silane & $7803-62-5$ & Pyrophoric & Gas & $100 \mathrm{scf}$ \\
\hline Silicon tetrachloride & $10026-04-7$ & $\begin{array}{l}\text { Corrosive, water reactive Class } 2 \text {, } \\
\text { irritant }\end{array}$ & Liquid & $0.1 \mathrm{~L}=100 \mathrm{~g}$ \\
\hline Siloxane & $2370-88-9$ & Flammable Class Ic & Liquid & $30 \mathrm{~g}$ \\
\hline Sodium & $7440-23-5$ & $\begin{array}{l}\text { Corrosive, flammable solid, water } \\
\text { reactive Class } 3\end{array}$ & Solid & $50 \mathrm{~g}$ \\
\hline Sodium hydroxide & $1310-73-2$ & Caustic, corrosive & Liquid & $7.5 \mathrm{~kg}$ \\
\hline $\begin{array}{l}\text { Sodium sulfide in aqua regia, natrium } \\
\text { gold sulfide }\end{array}$ & & Corrosive, toxic & Liquid & $20 \mathrm{~L}$ \\
\hline Stripper & & Flammable liquid Class IB & Liquid & $16 \mathrm{~L}$ \\
\hline SU-8 (Microchem) negative epoxy resist & & & Liquid & $8 \mathrm{~L}$ \\
\hline SU-8 2000 (Microchem) resist & & & Liquid & $8 \mathrm{~L}$ \\
\hline SU-8 resist developer & & & Liquid & $16 \mathrm{~L}$ \\
\hline Sulfur hexafluoride & $2251-62-4$ & Asphyxiant & Gas & $300 \mathrm{scf}$ \\
\hline Sulfuric acid & $7664-93-9$ & $\begin{array}{l}\text { Acid, corrosive, oxidizer Class } 2 \text {, } \\
\text { water reactive Class } 2\end{array}$ & Liquid & $12 \mathrm{~L}$ \\
\hline Teteraethylorthosilicate & $78-10-4$ & $\begin{array}{l}\text { Combustible liquid Class II, } \\
\text { irritant }\end{array}$ & Liquid & $1.1 \mathrm{~L}$ \\
\hline Tetrafluoroethane & & Toxic, asphyxiant & Gas & $516 \mathrm{scf}$ \\
\hline Tetrahydrofuran & 109-99-9 & Flammable liquid Class IB & Liquid & $12 \mathrm{~L}$ \\
\hline Thiols & & Flammable liquid Class IB & Liquid & $2 \mathrm{~L}$ \\
\hline TMAH developer & & Caustic, corrosive, toxic & Liquid & $32 \mathrm{~L}$ \\
\hline Toluene & $108-88-3$ & Flammable liquid Class IB, toxic & Liquid & $4 \mathrm{~L}$ \\
\hline Trifluoromethane & $75-46-7$ & & Gas & $16 \mathrm{scf}$ \\
\hline Tungsten carbonyl & $14040-11-0$ & Toxic, unstable Class 1 & Solid & $50 \mathrm{~g}$ \\
\hline Tungsten hexacarbonyl & & toxic & Solid & $50 \mathrm{~g}$ \\
\hline Various acids & & Acid, corrosive, oxidizer Class 2 & Liquid & $16 \mathrm{~L}$ \\
\hline Various bases & Various & Caustic, corrosive, toxic & Liquid & $7.5 \mathrm{~kg}$ \\
\hline
\end{tabular}


TABLE B.1 (Cont.)

\begin{tabular}{|c|c|c|c|c|}
\hline Common Name & CAS No. & Hazard & $\begin{array}{c}\text { Physical } \\
\text { Form } \\
\end{array}$ & Quantity \\
\hline Various electrolytes & Various & Corrosive & Liquid & $6 \mathrm{~L}$ \\
\hline Various metalorganic liquids & & Highly toxic, flammable Class IB & Liquid & $100 \mathrm{~g}$ \\
\hline Various metalorganic liquids & & Toxic, flammable Class IB & Liquid & $6 \mathrm{~L}$ \\
\hline Xenon - inert gas & $7440-63-3$ & Asphyxiant & Gas & $70 \mathrm{scf}$ \\
\hline Xenon difluoride & $13709-36-9$ & Irritant, unstable Class 2 & Solid & $15 \mathrm{~g}$ \\
\hline Xylenes & $1330-20-7$ & Flammable liquid Class IC & Liquid & $4 \mathrm{~L}$ \\
\hline ZED-N50 (Zeon Corp) ZEP developer & & & Liquid & $8 \mathrm{~L}$ \\
\hline ZEP 520A (Zeon Corp) resist & & & Liquid & $4 \mathrm{~L}$ \\
\hline ZMD-B EB- ZEP resist rinse & & & Liquid & $8 \mathrm{~L}$ \\
\hline
\end{tabular}

including those being conducted by ANL-E researchers as well as external collaborators, would be subject to critical hazard analysis through the application of ANL-E's Integrated Safety Management (ISM) protocols to ensure that CNM engineering design capabilities are not exceeded and that appropriate engineered, procedural, and administrative controls are identified and installed. In addition to the chemical and physical hazards posed by many of the chemicals that would be used, some biological agents may also be studied at the CNM. Biological Safety Level-2 (BSL-2) engineered, procedural, and administrative controls would be established to support any research involving biohazardous materials. The current experimental horizon for the CNM does not involve the use of radioactive materials, except potentially for radioisotopelabeled biological materials. Activation of nanoscale targets exposed to the APS beamline is considered to not be possible given the nature of radiation exposures that would occur.

Wastes can be expected to result from most aspects of CNM experimental activities; however, the majority of wastes would be associated with nanoscale material fabrication and patterning. The chemicals listed in Table B.1 as well as the technologies discussed above provide some insight into the types of wastes that can be anticipated. These include Resource Conservation and Recovery Act (RCRA) hazardous waste, such as spent RCRA-listed and RCRA-characteristic solvents, aqueous corrosive solutions resulting from spent electroplating baths or chemical etchant baths, off-specification or excess RCRA-listed chemicals, toxic wastes (including both organic and organo-metallic compounds), some aqueous wash solutions, and nonhazardous chemical wastes. In addition to chemical wastes directly related to experimental activities, nonhazardous solid wastes typical of office operations would also be generated at the $\mathrm{CNM}$, as well as both hazardous and nonhazardous industrial wastes resulting from maintenance of the facility infrastructure. Research involving biological agents may generate limited quantities of biohazard wastes that would require special handling that may include 
decontamination at the CNM and/or disposal at off-site appropriately permitted facilities. All wastes generated within the CNM are expected to be managed through existing ANL-E waste handling and disposal procedures, through the assistance of the Waste Management Operations (WMO) Division of ANL-E's Plant and Facility Services (PFS). ${ }^{2}$ Liquid wastes (e.g., solvents) would be captured, containerized, and initially stored with other current APS wastes at the designated initial waste accumulation point until removal by WMO personnel. Some acidic and corrosive wastes would be discharged to the CNM facility's acid neutralization tank. Following neutralization and characterization, the contents of this tank could be released into the ANL-E wastewater treatment system. HEPA filters that would be periodically replaced would be managed through WMO in a manner consistent with the characteristics they display. Likewise, scrubber water would be captured, characterized, and ultimately managed through WMO. Additional wastewaters expected to be generated would be detergent wash solutions that would be discharged to laboratory sinks that are plumbed to the ANL-E industrial waste treatment plant. Techniques would be in place to replenish electroplating baths and etchant baths to minimize wastes. Disposal is expected to be accomplished through the use of commercial off-site facilities in accordance with existing WMO protocols. WMO would also provide support for disposal of any biological wastes that are generated.

Because of the fluidity of activities expected in any research and development venture, a precise characterization and quantitation of all CNM-related wastes is not possible. However, the intrinsically small scale at which individual CNM operations would be conducted, the basic facility design, and administrative controls established through the ANL-E Safety Analysis Review (SAR) process all support the assumption that impacts to experimenters and to the environment from CNM activities would be initially very small and further mitigated by administrative and engineering controls. Wastes can be expected to be generated in relatively small volumes (e.g., grams, liters, or gallons per month), and existing waste management capacities at ANL-E can be expected to easily absorb what are expected to be insignificant increases to ANL-E waste volumes from CNM-related activities.

2 As is the current policy within APS, at the end of the experiment, external collaborators would be required to remove all remaining samples and excess chemicals that they have brought to the site. WMO would support the external researchers in these activities. 
ENVIRONMENTAL PERMITS IN EFFECT AS OF DECEMBER 31, 2001, AT ARGONNE NATIONAL LABORATORY-EAST 


$$
\text { C-2 }
$$




\section{APPENDIX C:}

ENVIRONMENTAL PERMITS IN EFFECT AS OF DECEMBER 31, 2001, AT ARGONNE NATIONAL LABORATORY-EAST

\begin{tabular}{|c|c|c|c|}
\hline Type & Subject of Permit & Building & $\begin{array}{c}\text { Expiration } \\
\text { Date }\end{array}$ \\
\hline Air & Title V-ANL-E & Sitewide & $4 / 3 / 01$ \\
\hline Air & ALEX Alkali Metal Scrubber ${ }^{\mathrm{a}}$ & 370 & Incorporated Title V \\
\hline Air & Alkali Metal Reaction Booth ${ }^{\mathrm{a}}$ & 308 & Incorporated Title V \\
\hline Air & APS Emergency Generators (3) & 400 & Incorporated Title V \\
\hline Air & Argonne Service Station & 300 & Incorporated Title V \\
\hline Air & Boiler No. 5 Low $\mathrm{NO}_{\mathrm{x}}$ Gas Burnerb & 108 & Incorporated Title $\mathrm{V}$ \\
\hline Air & Central Heating Plant & 108 & Incorporated Title V \\
\hline Air & Central Shops Dust Collector ${ }^{\mathrm{a}}$ & 363 & Incorporated Title V \\
\hline Air & Gasoline Dispensing Facility ${ }^{c}$ & 46 & Incorporated Title V \\
\hline Air & Salt Cake/Recovery Electrodialysis Plant & 369 & Incorporated Title V \\
\hline Air & Sulfuric Acid Storage Tank ${ }^{\mathrm{a}}$ & 108 & Incorporated Title V \\
\hline Air & Torch Cutting (Welding) Fumes ${ }^{\mathrm{a}}$ & Sitewide & Incorporated Title V \\
\hline Air & Transportation Research Facility & 376 & Incorporated Title V \\
\hline Air & Wood Shop Dust Collector ${ }^{\mathrm{a}}$ & 368 & Incorporated Title V \\
\hline Air & Waste Bulking Sheds ${ }^{\mathrm{a}, \mathrm{d}}$ & 306 & Incorporated Title V \\
\hline Air & Open-Burning Permit - Fire Dept. ${ }^{\mathrm{a}}$ & 333 & $04 / 18 / 01$ \\
\hline Air & Open Burning - Vegetation & Sitewide & $01 / 29 / 01$ \\
\hline NESHAP & Advanced Photon Source & 400 & Incorporated Title V \\
\hline NESHAP & Alkali Metal Reaction Booth & 206 & Incorporated Title $\mathrm{V}$ \\
\hline NESHAP & Alpha Gamma Hot Cell Facility & 212 & Incorporated Title V \\
\hline NESHAP & Building Exhausts ${ }^{\mathrm{a}, \mathrm{e}}$ & 212 & Incorporated Title V \\
\hline NESHAP & Building Rehab - Phase $1^{\mathrm{d}}$ & 306 & Incorporated Title $\mathrm{V}$ \\
\hline NESHAP & Building Vents & 306 & Incorporated Title V \\
\hline NESHAP & Chemical Photooxid. Vial Crusher ${ }^{f}$ & 306 & Incorporated Title V \\
\hline NESHAP & CP-5 D\&D Project & 330 & Incorporated Title V \\
\hline NESHAP & Building 301 Hot Cell D\&D Project & 301 & Incorporated Title V \\
\hline NESHAP & Intense Pulsed Neutron Source & 375 & Incorporated Title $\mathrm{V}$ \\
\hline NESHAP & Lab Wastewater Treatment Plant & 575 & Incorporated Title V \\
\hline NESHAP & Lead Brick Cleaning (carbon dioxide) & $200 / 317$ & Incorporated Title V \\
\hline NESHAP & Melt Attack/Coolability Experiment & 315 & Incorporated Title V \\
\hline NESHAP & Mixed Waste Storage Facility & 303 & Incorporated Title V \\
\hline NESHAP & M-Wing Hot Cells & 200 & Incorporated Title V \\
\hline NESHAP & New Brunswick Lab Hoods & 350 & Incorporated Title V \\
\hline NESHAP & PCB Tank Cleanoutg & Sitewide & Incorporated Title V \\
\hline NESHAP & Rad Hoods & Sitewide & Incorporated Title V \\
\hline
\end{tabular}




\begin{tabular}{|c|c|c|c|c|}
\hline Type & Subject of Permit & Building & Issued & $\begin{array}{c}\text { Expiration } \\
\text { Date }\end{array}$ \\
\hline NESHAP & Rad (TRUW) Waste Storage Facility & 331 & \multicolumn{2}{|c|}{ Incorporated Title $\mathrm{V}$} \\
\hline NESHAP & WMO Portable HEPA Filtersg & 306 & \multicolumn{2}{|c|}{ Incorporated Title V } \\
\hline NESHAP & WMO HEPA Filter Systems $(6)^{\mathrm{h}, \mathrm{i}}$ & Sitewide & \multicolumn{2}{|c|}{ Incorporated Title V } \\
\hline Hazardous Waste & RCRA Part B & Sitewide & 09/30/97 & $11 / 04 / 07$ \\
\hline Miscellaneous & Deer Population Control Permit & Sitewide & $1 / 26 / 01$ & $02 / 23 / 02$ \\
\hline Miscellaneous & Nuisance Wildlife Control & Sitewide & $01 / 01 / 01$ & $01 / 31 / 02$ \\
\hline Solid Waste & Landfill & 800 Area & $03 / 31 / 82$ & j \\
\hline Solid Waste & Landfill & 800 Area & 03/30/89 & - \\
\hline Solid Waste & Landfill & 800 Area & $04 / 12 / 89$ & - \\
\hline Solid Waste & Landfill Groundwater Assessment & 800 Area & $09 / 30 / 91$ & - \\
\hline Solid Waste & Landfill Leachate Characterization & 800 Area & $09 / 30 / 91$ & - \\
\hline Solid Waste & Landfill Leachate Test Wells & 800 Area & $08 / 31 / 90$ & - \\
\hline Solid Waste & Landfill Revised Closure Plan ${ }^{k}$ & 800 Area & $04 / 24 / 92$ & - \\
\hline Solid Waste & Landfill Supplemental Closure Plan & 800 Area & $09 / 15 / 92$ & - \\
\hline Solid Waste & Landfill Supplemental Permit Groundwater & 800 Area & $04 / 19 / 94$ & - \\
\hline Solid Waste & Landfill Supplemental Permit Groundwater & 800 Area & $01 / 11 / 95$ & - \\
\hline Solid Waste & Landfill Supplemental Permit Groundwater & 800 Area & $11 / 20 / 97$ & - \\
\hline Solid Waste & Landfill Supplemental Permit Groundwater & 800 Area & $08 / 25 / 98$ & - \\
\hline Solid Waste & Landfill Supplemental Permit Groundwater & 800 Area & 06/16/99 & - \\
\hline Solid Waste & Landfill Supplemental Permit Groundwater & 800 Area & $4 / 25 / 00$ & - \\
\hline Water & Lime Sludge Application - Land Application & Sitewide & $10 / 30 / 98$ & $10 / 31 / 02$ \\
\hline Water & NPDES Permitted Outfalls ${ }^{1}$ & Sitewide & $10 / 31 / 94$ & 07/01/99 \\
\hline Water & NPDES Stormwater Outfalls ${ }^{1}$ & Sitewide & $10 / 31 / 94$ & 07/01/99 \\
\hline
\end{tabular}

Abbreviations: ALEX = Argonne Liquid-Metal Experiment; APS = Advanced Photon Source; CP-5 = Chicago Pile-5 Reactor; D\&D = decontamination and decommissioning; HEPA = high-efficiency particulate air; IEPA = Illinois Environmental Protection Agency; NESHAP = National Emissions Standards for Hazardous Air Pollutants; NPDES = National Pollution Discharge Elimination System; PCB = polychlorinated biphenyl; RCRA = Resource Conservation and Recovery Act; TRUW = transuranic hazardous waste; $\mathrm{WMO}=$ Waste Management Operations.

a These units have been designated as insignificant sources in the ANL-E Title V permit.

b Construction permit issued; operated under the Central Heating Plant permit.

c Included the ethanol/gasoline tank. In October 2001, the methanol/gasoline tank was converted to ethanol/gasoline storage.

d Construction permit issued; operated under the Building 306 permit.

e The plasma spray booth was added to the permit on May 27, 1984.

f The vial crusher was originally issued under the Building 306 permit.

$\mathrm{g}$ Construction permit issued; operated under the WMO HEPA permit. 
(Cont.)

h The construction permit added two portable HEPA filters to the existing four filters.

i The construction permit was originally issued October 15, 2001, and was used for operations until Clean Air Act Permit Program (CAAPP) Permit Renewal.

j A hyphen indicates superceded by the next permit.

$\mathrm{k}$ Includes the gas monitoring program.

1 The existing permit continues to be in effect while the revised permit application is undergoing IEPA review.

Source: Golchert, N.W., and R.G. Kolzow, 2002, Site Environmental Report for Calendar Year 2001, ANL-02/2, Argonne National Laboratory, Argonne, Ill., Sept. 
APPENDIX D:

\section{CALCULATIONS RELATED TO CONTAMINANTS IN}

PARKING LOT STORMWATER RUNOFF 


$$
\text { D-2 }
$$




\section{APPENDIX D:}

\section{CALCULATIONS RELATED TO CONTAMINANTS IN PARKING LOT STORMWATER RUNOFF}

Construction of the Center for Nanoscale Materials (CNM) facility would modify the surface configuration of the land southeast of the intersection of Kearney and Rock Roads at Argonne National Laboratory-East (ANL-E). This area is currently occupied by a detention area for surface runoff for 14.1 acres of land occupied by buildings, roads, parking areas and lawns. The construction of the CNM facility would modify the surface configuration of this area and add buildings, driveways, walkways, and parking areas. Driveways and walkways would be salted to protect workers and visitors during freezing conditions. Parking areas would collect automotive fluids and other contaminants from vehicles. When dissolved or lifted by precipitation, these salts and other contaminants could reach Wetland 302, which is downstream and directly across Rock Road from the proposed CNM site. Wetland 302 is a jurisdictional wetland and is maintained as mitigation for past, present, and future impacts to wetlands at ANL-E. To protect the wetland it is important to keep contaminants from entering the drainage system and affecting wetland vegetation. This appendix describes a series of calculations that were used to evaluate potential contaminants resulting from precipitation washing salts and other materials from walkways, roadways, and parking areas associated with the CNM and other areas in the Wetland 302 watershed.

\section{D.1 AREAS}

Three areas were examined in the evaluation of contaminant management (Table D.1). The largest area included the entire catchment area of Wetland 302. The smallest area included the proposed CNM site and portions of the APS ring and APS infield that currently drain into the retention area at the corner of Kearney and Rock Roads. From this retention area, drainage flows under Rock Roads to immediately combine with drainage from the southwest corner of the ANL-E site. This area west of Kearney Road is called the SW Catchment Area. Table D.1 includes the total surface area of these three catchment areas. The table also indicates the surface areas that are impervious to precipitation and are either salted ( i.e., paved areas) or unsalted (i.e., building roofs). The table also indicates the area that is pervious, that is where precipitation is assumed to soak into the ground. It is assumed that $100 \%$ of precipitation runs off of impervious areas and into drainage ways. It is assumed that less than $100 \%$ of precipitation runs off of pervious surfaces and into drainage ways. The actual percentage that runs off of pervious surfaces depends on such factors as vegetation; soil type, compaction, and moisture; slope; and precipitation rate. For the analysis of salting and salt yield, it was assumed that no runoff occurred during snowmelt conditions in the winter and early spring. For an analysis of contaminant yields over various storm events, which may occur in the spring and summer, 30\% runoff was assumed to represent an average value for the purposes of calculations of water yield. 
TABLE D.1 Surface Areas of Land and Facilities within Wetland 302 Watershed

\begin{tabular}{|c|c|c|c|c|}
\hline Area & Description & $\begin{array}{l}\text { Existing } \\
\text { Conditions } \\
\text { (acres) }^{\mathrm{a}}\end{array}$ & $\begin{array}{l}\text { CNM, North } \\
\text { Parking } \\
\text { (acres) }^{\mathrm{a}}\end{array}$ & $\begin{array}{l}\text { CNM, North } \\
\text { and South } \\
\text { Parking } \\
\text { (acres) }^{\mathrm{a}}\end{array}$ \\
\hline \multirow[t]{4}{*}{ Wetland 302: Catchment } & Total & 129.234 & 127.750 & 127.750 \\
\hline & Impervious area-salted & 9.758 & 10.094 & 9.412 \\
\hline & Impervious area-unsalted & 7.145 & 8.837 & 8.837 \\
\hline & Pervious area & 112.331 & 108.819 & 109.501 \\
\hline \multirow[t]{4}{*}{ CNM Drainage Area } & Total & 14.104 & 12.620 & 12.620 \\
\hline & Impervious area-salted & 1.719 & 2.029 & 1.348 \\
\hline & Impervious area-unsalted & 3.400 & 5.090 & 5.090 \\
\hline & Pervious Area & 9.021 & 5.501 & 6.213 \\
\hline \multirow[t]{4}{*}{ Wetland 302: SW Catchment } & Total & 32.925 & 32.925 & 32.925 \\
\hline & Impervious area-salted & 0.316 & 0.316 & 0.316 \\
\hline & Impervious area-unsalted & 0.010 & 0.010 & 0.010 \\
\hline & Pervious area & 32.599 & 32.599 & 32.599 \\
\hline
\end{tabular}

a 1 acre equals $43,560 \mathrm{ft}^{2}$, or 0.40469 hectare (ha).

\section{D.2 SALT CONCENTRATIONS IN SITE RUNOFF}

\section{D.2.1 Introduction and Approach}

This salt application analysis focuses on the CNM watershed, which discharges all of its runoff to Wetland 302 by means of a culvert under Rock Road, at the intersection of Rock and Kearney Roads. The CNM watershed includes salted roads (including a length of the south side of Rock Road and a length of the east side of Kearney Road), driveways, sidewalks, and parking lots (both current and proposed); building rooftops (both current and proposed); drainage from a portion of the center of APS conveyed by pipe under the APS building; and assorted pervious surfaces (both current and resulting from proposed construction), including lawns and road shoulders. The northern and northeastern portions of the CNM watershed drain into a ditch that flows west along Rock Road. Much of the rest of the watershed flows through ditches and culverts to reach the drainage basin currently at the southwest corner of the intersection of Kearney and Rock Roads. Here the flow joins the flow from the Rock Road ditch and enters a culvert under Rock Road to flow north into Wetland 302. On the north side of Rock Road, the culvert discharge is joined by flow from a culvert under Kearney Road that collects runoff from forested ANL-E property west of Kearney and from the ditch along the west side of Kearney. All of these ditches and culverts convey varying amounts of water, depending on the recent weather, and are likely either not flowing or totally dry for a large proportion of each year. 
A geographic information system (GIS) analysis was used to determine the area of salted surfaces (roads, parking lots, sidewalks) (Table D.1). Gravel roads and other areas assumed to be unsalted and were ignored in the analysis. Salt was assumed to be spread uniformly over site roads and parking lots, although it is possible that some areas are salted heavier than others. Estimating the concentration of salt or chloride may follow a multitude of possible approaches. In this case, the estimation of the amount of salt loading from the CNM drainage basin was made using a lumped parameter approach, in which various sources of solute and solvent (water) are lumped together to determine an overall concentration at the watershed's outlet culvert.

The analysis needs to include a variety of different factors related to the salt application method, the amount of melted snow or rain available as runoff, and drainage and infiltration characteristics of a relevant watershed. This information can be combined to determine an estimated concentration at a given location and relevant to a particular time or time interval. Each salting event differs in terms of many factors, which may include:

- The salt application rate (mass/unit area),

- The number of salt applications if the snowstorm is prolonged,

- Amount of snowfall prior to plowing,

- Amount of snowfall following plowing and salting,

- Whether the individual plow driver plows the snow off a parking lot onto grass or into a pile in parking spaces,

- Whether surfaces are plowed at all or only salted,

- Temperature of pavement and ground,

- Type of snow or freezing rain,

- Timing of snowmelt and possible ground thaw, and

- Transient nature of salt dissolution and salt concentration in runoff from individual surfaces.

Because of these complicated factors, the winter season as a whole is considered in this analysis, rather than making estimates for individual salting events. In this manner, the season's salt application may be taken in total and be compared with the precipitation over the season. Data available over the season are more accurate than event-scale data for both salt usage and, especially, hydrologic factors such as precipitation and runoff.

Precipitation in DuPage County is 33.4 in. per year (USDA 1979). Of this annual average, 9.6 in. falls as snow, rain, or freezing rain during the winter salting season, assumed here to be November to March. A detailed rainfall-runoff analysis of the CNM watershed is 
beyond the scope of this analysis. Such a study would require a great deal of data, such as soil characteristics (structure, porosity, moisture content, frozen/thawed), vegetation mapping, precipitation assumptions (amount, intensity), and transient aspects of many of these factors. Instead, the approach followed considers that wintertime soil conditions may range from thawed (and allowing all water to infiltrate the pervious areas) to completely frozen (and allowing all water to run off the pervious areas). A bracketing approach is followed, in which the concentration at the CNM discharge outlet is calculated twice, once assuming that snowmelt completely soaks into the pervious portion of the CNM watershed (e.g., lawns, etc.) and contributes no runoff, and again assuming that pervious areas are frozen and all precipitation on the pervious areas runs off. While neither assumption yields "expected" values for runoff or infiltration proportions (during a season, both conditions may occur at different periods), they serve as a means of estimating the range of expected values in runoff. In turn they are used in estimating the range of values in chloride concentrations in watershed runoff. In each case, the impervious areas are assumed to contribute all their runoff to the outlet point.

\section{D.2.2 Results}

Annually, Argonne uses 800 to 1,000 tons of salt (Powell 2003). Assuming an average use of 900 tons, the average salt loading is $167,000 \mathrm{mg}$ per $\mathrm{ft}^{2}$ of salted pavement per year. Road salt is primarily sodium chloride. Chloride is the more critical ion in terms of environmental impact (TRB 1991). Salt is $60.7 \%$ chloride by weight. The seasonal salt loading was therefore converted from salt to chloride for use in calculating chloride concentrations.

Table D.2 presents the calculated chloride concentration in runoff from the CNM drainage area for the bounding assumption that the pervious ground remains frozen throughout the winter season, and the assumption that the pervious ground remains unfrozen during the winter season. This table includes the following scenarios:

- Current conditions: land contours and buildings remain without modification (no action).

- Alternative A: the CNM is constructed, land contoured, a 40,000- $\mathrm{ft}^{2}$ parking lot is constructed north of the CNM, and a collection basin and pump are installed to remove the $90 \%$ of the salt and contaminates washed from the parking lot by melt water and precipitation. The pumped drainage would be sent out of the Wetland 302 watershed.

- Alternative B: the CNM is constructed, land contoured, and a 40,000- $\mathrm{ft}^{2}$ parking lot is constructed with bioswales to remove other contaminants, but not chlorides.

- Alternative C: the CNM is constructed, land contoured, a 16,000- $\mathrm{ft}^{2}$ parking lot is constructed north of the CNM, and a 37,000- $\mathrm{ft}^{2}$ parking lot is constructed south of the CNM outside of the Wetland 302 watershed. 


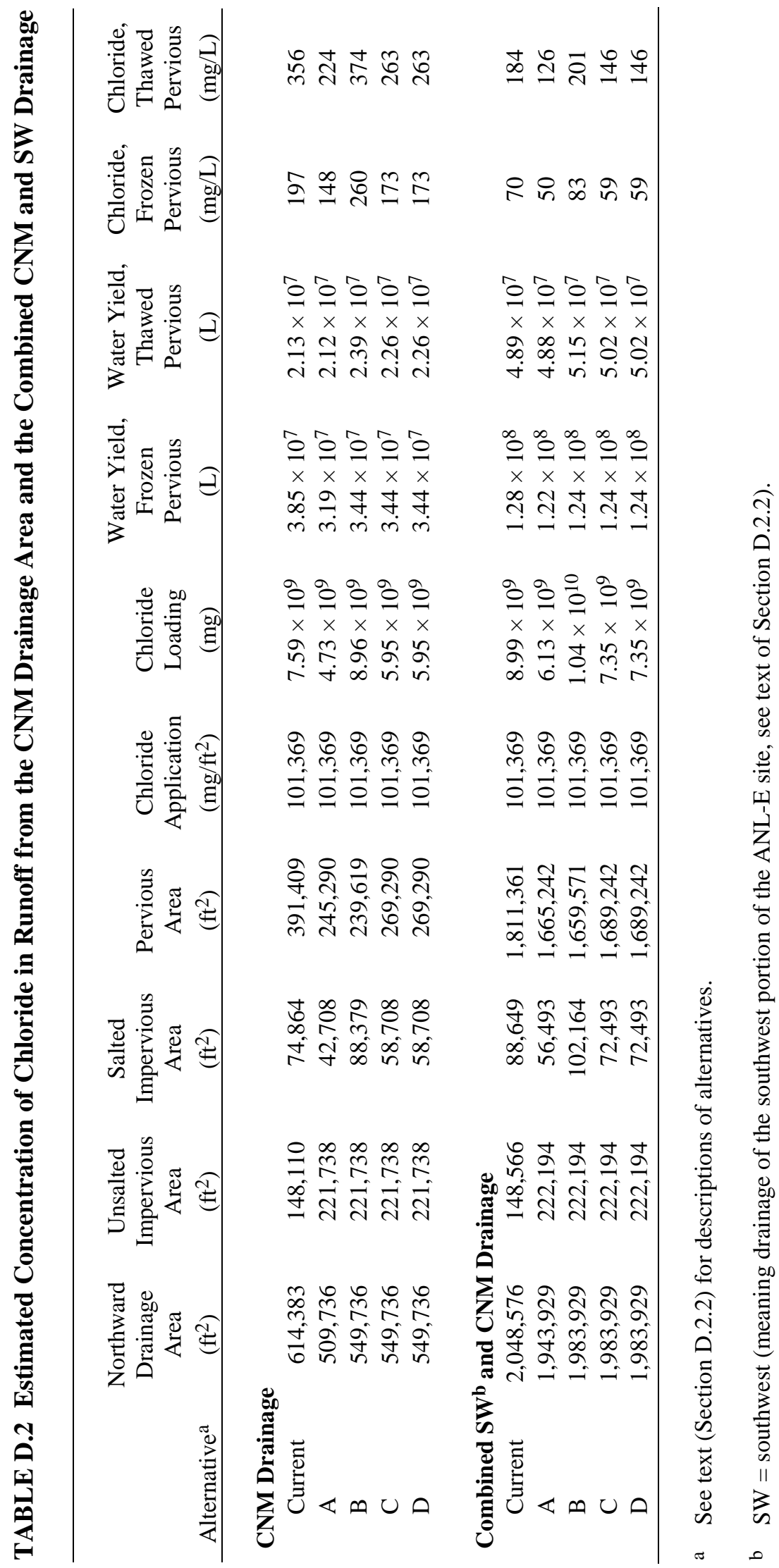


- Alternative D: the CNM is constructed, land contoured, a 16,000- $\mathrm{ft}^{2}$ parking lot is constructed north of the CNM, and a tiered parking structure is constructed south of the CNM outside of the Wetland 302 watershed.

A chloride level of $168 \mathrm{mg} / \mathrm{L}$ is the benchmark value developed for this EA for protection of wetland vegetation, as described in Chapter 4. At the assumed application rate of $167,000 \mathrm{mg} / \mathrm{ft}^{2}$, the current conditions result in chloride concentrations from the CNM drainage area above this value for both frozen and thawed pervious ground. Current conditions and all alternative parking configurations also result in chloride concentrations above the benchmark value for when pervious ground is thawed. The only alternative that yields chloride concentrations below the benchmark value is A, the proposed action, in which parking lot drainage would be pumped south.

Drainage from the CNM area joins with drainage from the southwest portion of the ANL-E site prior to entering Wetland 302. Salt concentrations for the combined drainage are also shown in Table D.2. While chloride concentrations would be below benchmark values for all alternatives during frozen conditions, both the existing conditions and alternative $\mathrm{B}$ result in concentrations above benchmark values during thawed conditions. Under thawed conditions, the chloride concentrations are $69 \%$ of benchmark values for the proposed action (A) and $87 \%$ of benchmark values for alternatives where parking is constructed south of the CNM (C and D).

Various highway references were examined to gain an understanding of recommended salt usage on various roads in northern states and Canadian provinces. These suggest a range of 757 to $1,893 \mathrm{mg}$ salt per $\mathrm{ft}^{2}$ of highway per salting event. These values, however, represent highway application rates. The USGS (Heisig 1999) related state route salt application in New York State to highway application rates. The application on 4-lane highways exceeded the state route by a factor of two; interstates were higher by a factor of eight. It is reasonable to assume that the salt loading on Argonne roads and parking areas could be reduced below 167,000 mg/ft ${ }^{2}$, thereby also providing wetland protection.

\section{D.3 OTHER CONTAMINANTS}

Parking lots gather other contaminants besides salt. These contaminants include oils, automotive fluids, rubber, and trace metals. It is generally assumed that the majority of contaminants are removed from the surface of paved areas during the "first flush" of runoff during precipitation events. Collection of this runoff would allow pumping of the water to the south out of the Wetland 302 watershed.

Precipitation events of short duration may be intense, as shown in Table D.3 which presents the gallons per minute that could be generated by rainfall on the CNM parking lot for different events of different durations and return periods, as listed in Huff and Angel (1989). In order to capture short-duration rainfall and the first flush of longer-duration rainfall, pumping would either be sized to the maximum runoff rate or a collection system would be used to allow 
TABLE D.3 Potential Runoff Rate from the CNM Parking Lot

\begin{tabular}{lrrrrrrr}
\hline & \multicolumn{7}{c}{ Runoff Rate $(\mathrm{gpm})$ by Return Period } \\
\cline { 2 - 8 } Duration & 1-year & 2-year & 5-year & 10-year & 25-year & 50 -year & 100-year \\
\hline & & & & & & & \\
10-day & 7 & 9 & 11 & 12 & 15 & 17 & 20 \\
5-day & 12 & 14 & 18 & 21 & 25 & 29 & 36 \\
72-hour & 18 & 21 & 27 & 33 & 40 & 46 & 53 \\
48-hour & 24 & 30 & 37 & 47 & 57 & 67 & 79 \\
24-hour & 45 & 55 & 69 & 81 & 99 & 117 & 137 \\
18-hour & 55 & 67 & 84 & 99 & 122 & 143 & 168 \\
12-hour & 79 & 95 & 120 & 140 & 173 & 203 & 238 \\
6-hour & 136 & 165 & 206 & 242 & 298 & 350 & 410 \\
3-hour & 231 & 280 & 351 & 413 & 510 & 598 & 701 \\
2-hour & 321 & 388 & 485 & 572 & 704 & 828 & 969 \\
1-hour & 511 & 620 & 776 & 910 & 1,122 & 1,317 & 1,543 \\
30-minute & 806 & 971 & 1,222 & 1,430 & 1,768 & 2,071 & 2,427 \\
15-minute & 1,179 & 1,421 & 1,785 & 2,097 & 2,583 & 3,033 & 3,553 \\
10-minute & 1,430 & 1,742 & 2,184 & 2,548 & 3,146 & 3,692 & 4,342 \\
5-minute & 1,560 & 1,872 & 2,444 & 2,808 & 3,432 & 4,056 & 4,732 \\
\hline
\end{tabular}

smaller pumps to move the collected water over a longer period of time. For the proposed action, a collection basin would be used to collect the initial runoff from precipitation events to allow pumping of this water to the south out of the Wetland 302 watershed.

To compute the collection requirements for different events, a simple calculation was performed to determine the excess of runoff over pumping for storm durations of 5 minutes to 10 days for return periods of 1 to 100 years (Huff and Angel 1989). Table D.4 shows the retention capacity needed to completely contain the runoff from the CNM parking lot with a pumping rate of $80 \mathrm{gpm}$. Table D.5 presents the retention capacity needed to completely contain the runoff from the CNM parking lot with a pumping rate of $200 \mathrm{gpm}$. It was further assumed that contaminants collecting on the parking surfaces would be washed off the surface and be carried with the runoff during the first portion of the rain event. The assumption was that $90 \%$ of the contaminants would be washed off in the 0.5 -in. of rainfall. In northern Illinois, this would be a 1-year, 10-minute event of 0.55 in.; a 2-year, 10 -minute event of 0.57 in.; and a 5-year, 5-minute event of 0.47 in. (Huff and Angel 1989). With a 200-gpm pumping rate, the storage capacity needed for these events would be 11,750 gal, 14,750 gal, and 10,750 gal, respectively (Table D.5). Thus, for a 5-year return period, 0.5-in. rain events would be contained by a collection capacity of 14,750 gal, or $1,967 \mathrm{ft}^{3}$.

Further contaminant removal could be accomplished by collecting the first inch of rainfall. In northeastern Illinois, this would be a 1-year, 1-hour event of 1.18 in.; a 2-year, 30-minute event of 1.12 in.; and a 5-year, 15-minute event of 1.03 in. (Huff and Angel 1989). 
TABLE D.4 Collection Capacity Required to Contain Runoff from the CNM Parking Area with Pumping Rate of 80 gpm

\begin{tabular}{|c|c|c|c|c|c|c|c|}
\hline \multirow[b]{2}{*}{ Duration } & \multicolumn{7}{|c|}{ Capacity (gal) Required by Return Period } \\
\hline & 1-year & 2-year & 5-year & 10-year & 25-year & 50-year & 100-year \\
\hline 10-day & None & None & None & None & None & None & None \\
\hline 5-day & None & None & None & None & None & None & None \\
\hline 72-hour & None & None & None & None & None & None & None \\
\hline 48-hour & None & None & None & None & None & None & None \\
\hline 24-hour & None & None & None & None & 22,550 & 46,300 & 74,300 \\
\hline 18-hour & None & None & 1,100 & 16,350 & 40,100 & 62,350 & 87,850 \\
\hline 12-hour & None & 8,400 & 25,150 & 39,650 & 62,150 & 82,900 & 107,150 \\
\hline 6-hour & 18,200 & 28,200 & 42,450 & 54,950 & 74,450 & 92,450 & 113,200 \\
\hline 3-hour & 25,600 & 34,100 & 46,350 & 57,100 & 73,850 & 89,100 & 106,850 \\
\hline 2-hour & 27,400 & 35,150 & 46,400 & 56,400 & 71,650 & 85,900 & 102,150 \\
\hline 1-hour & 24,700 & 30,950 & 39,950 & 47,700 & 59,950 & 71,200 & 84,200 \\
\hline 30-minute & 20,850 & 25,600 & 32,850 & 38,850 & 48,600 & 57,350 & 67,600 \\
\hline 15-minute & 15,800 & 19,300 & 24,550 & 29,050 & 36,050 & 42,550 & 50,050 \\
\hline 10-minute & 12,950 & 15,950 & 20,200 & 23,700 & 29,450 & 34,700 & 40,950 \\
\hline 5-minute & 7,100 & 8,600 & 11,350 & 13,100 & 16,100 & 19,100 & 22,350 \\
\hline
\end{tabular}

TABLE D.5 Collection Capacity Required to Contain Runoff from the CNM Parking Area with Pumping Rate of 200 gpm

Capacity (gal) Required by Return Period

\begin{tabular}{lrrrrrrr}
\multicolumn{1}{c}{ Duration } & 1-year & 2-year & 5-year & 10-year & 25-year & 50-year & 100-year \\
\hline 10-day & None & None & None & None & None & None & None \\
5-day & None & None & None & None & None & None & None \\
72-hour & None & None & None & None & None & None & None \\
48-hour & None & None & None & None & None & None & None \\
24-hour & None & None & None & None & None & None & None \\
18-hour & None & None & None & None & None & None & None \\
12-hour & None & None & None & None & None & None & 20,750 \\
6-hour & None & None & None & 11,750 & 31,250 & 49,250 & 70,000 \\
3-hour & 4,000 & 12,500 & 24,750 & 35,500 & 52,250 & 67,500 & 85,250 \\
2-hour & 13,000 & 20,750 & 32,000 & 42,000 & 57,250 & 71,500 & 87,750 \\
1-hour & 17,500 & 23,750 & 32,750 & 40,500 & 52,750 & 64,000 & 77,000 \\
30-minute & 17,250 & 22,000 & 29,250 & 35,250 & 45,000 & 53,750 & 64,000 \\
15-minute & 14,000 & 17,500 & 22,750 & 27,250 & 34,250 & 40,750 & 48,250 \\
10-minute & 11,750 & 14,750 & 19,000 & 22,500 & 28,250 & 33,500 & 39,750 \\
5-minute & 6,500 & 8,000 & 10,750 & 12,500 & 15,500 & 18,500 & 21,750 \\
\hline
\end{tabular}


With a 200-gpm pumping rate, the storage capacity needed for these events are 17,500 gal, 22,000 gal, and 22,750 gal, respectively. Thus, for a 5-year period, 1-in. rain events would be contained by a collection capacity of 22,750 gal, or 3,033 $\mathrm{ft}^{3}$. Greater or lesser storage capacity would be needed for different pumping rates; $200 \mathrm{gpm}$ was chosen for analysis to represent $50 \%$ of the output of a 400 gpm pump. A pump of this size is currently used at Argonne to pump runoff from a coal storage area.

\section{D.4 REFERENCES FOR APPENDIX D}

Heisig, P.M., 1999, Effects of Residential and Agricultural Land Uses on the Chemical Quality of Baseflow of Small Streams in the Croton Watershed, Southeastern New York, WaterResources Investigations Report 99-4173, U.S. Geological Survey, available at http://ny.usgs.gov/pubs/wri/wri994173/.

Huff, F.A., and J.R. Angel, 1989, Rainfall Distributions and Hydroclimatic Characteristics of Heavy Rainstorms in Illinois, Bulletin 70, Table 1, Illinois State Water Survey, available at http://www.sws.uiuc.edu/atmos/statecli/RF/table10.txt, accessed May 10, 2003.

Powell, E., 2003, electronic mail from E. Powell (Plant Facilities and Services Division, Argonne National Laboratory) to J. Quinn (Environmental Assessment Division, Argonne National Laboratory), Jan. 9.

Transportation Research Board, 1991, Highway Deicing: Comparing Salt and Calcium Magnesium Acetate, Special Report 235, National Research Council, Washington, D.C., available at http://gulliver.trb.org/publications/sr/sr235.html.

TRB - see Transportation Research Board.

USDA - see U.S. Department of Agriculture.

U.S. Department of Agriculture, 1979, Soil Survey of DuPage and Part of Cook Counties, Illinois, Soil Conservation Service.

Wegner, W., and M. Yaggi, 2001, "Environmental Impacts of Road Salt and Alternatives in the New York City Watershed," Stormwater, July, available at http://www.forester.net/ sw_0107_environmental.html. 
D-12 
APPENDIX E:

EVALUATION OF ALTERNATIVE PARKING LOT SITING OPTIONS FOR THE CENTER FOR NANOSCALE MATERIALS 
E-2 


\section{APPENDIX E:}

\section{EVALUATION OF ALTERNATIVE PARKING LOT SITING OPTIONS FOR THE CENTER FOR NANOSCALE MATERIALS}

The Center for Nanoscale Materials (CNM) facility will require parking for approximately 100 vehicles. Four possible sites (Figure E.1) were considered in detail for this environmental assessment. This appendix describes the selection of the four alternative sites and the characteristics of each.

The proposed site for the main parking lot is immediately north of the proposed CNM facility southeast of the corner of Kearny and Rock Roads (Site 4 in Figure E.1). This area drains to the north into Wetland 302. Because of the sensitivity of this wetland to drainage and the designation of this wetland for mitigation purposes for other Argonne activities, alternative parking lot locations and parking design were considered.

Alternative sites examined included areas west of Kearney Road and areas south of the proposed CNM facility (Figure E.1) Sites 1 and 2 would both drain to the south. These sites are representative on any number of potential locations in this area. Site 3 is west of Kearney Road. Alternative design features considered include a two-tiered parking structure for Sites 1 and 2. Alternative drainage systems for Sites 3 and 4 include (1) drainage north into Wetland 302 or (2) collecting contaminated runoff from the parking lot and pumping the collected water south across Bluff Road and the southern ANL-E boundary. An alternative drainage system examined for Site 4 also included the incorporation of bioswales in parking lot design.

Table E.1 summarizes the features of these alternatives, and Table E.2 summarizes their environmental characteristics.

Site 1 would be somewhere south of the CNM and north of Bluff Road. It would be located to avoid locations of potential future development. Site 1 would drain to the south, following the natural slope. The site is situated such that stormwater runoff would travel through grassy areas before crossing the ANL-E fence line into Waterfall Glen Forest Preserve. The ANL-E NPDES permit would need to be modified for discharge of stormwater from and industrial facility. Traffic to Site 1 would be routed along Kearney Road on the west side of the CNM building. Parking lot No. 1 is far from the CNM facility; the occupants of LOM 437 and the CNM would need to walk $1 / 4$ to $1 / 2$ mile to reach the nearest parking sites, and up to 3,000 $\mathrm{ft}$ $(915 \mathrm{~m})$ of new walkways would be required. Two different design options were considered for Site 1. Option A would be for an open asphalt parking lot of $37,000 \mathrm{ft}^{2}\left(3,440 \mathrm{~m}^{2}\right)$. Option B would be for a two-tiered or multi-tiered parking lot that would serve the CNM and future development in the area. The footprint of such a facility would be $28,000 \mathrm{ft}^{2}\left(2,600 \mathrm{~m}^{2}\right)$.

Site 2 would be similar to Site 1, but located immediately south of the proposed CNM facility. A parking lot at Site 2 would be in an area of potential future development. Because of this conflict, Site 2 was not considered further in the EA. 


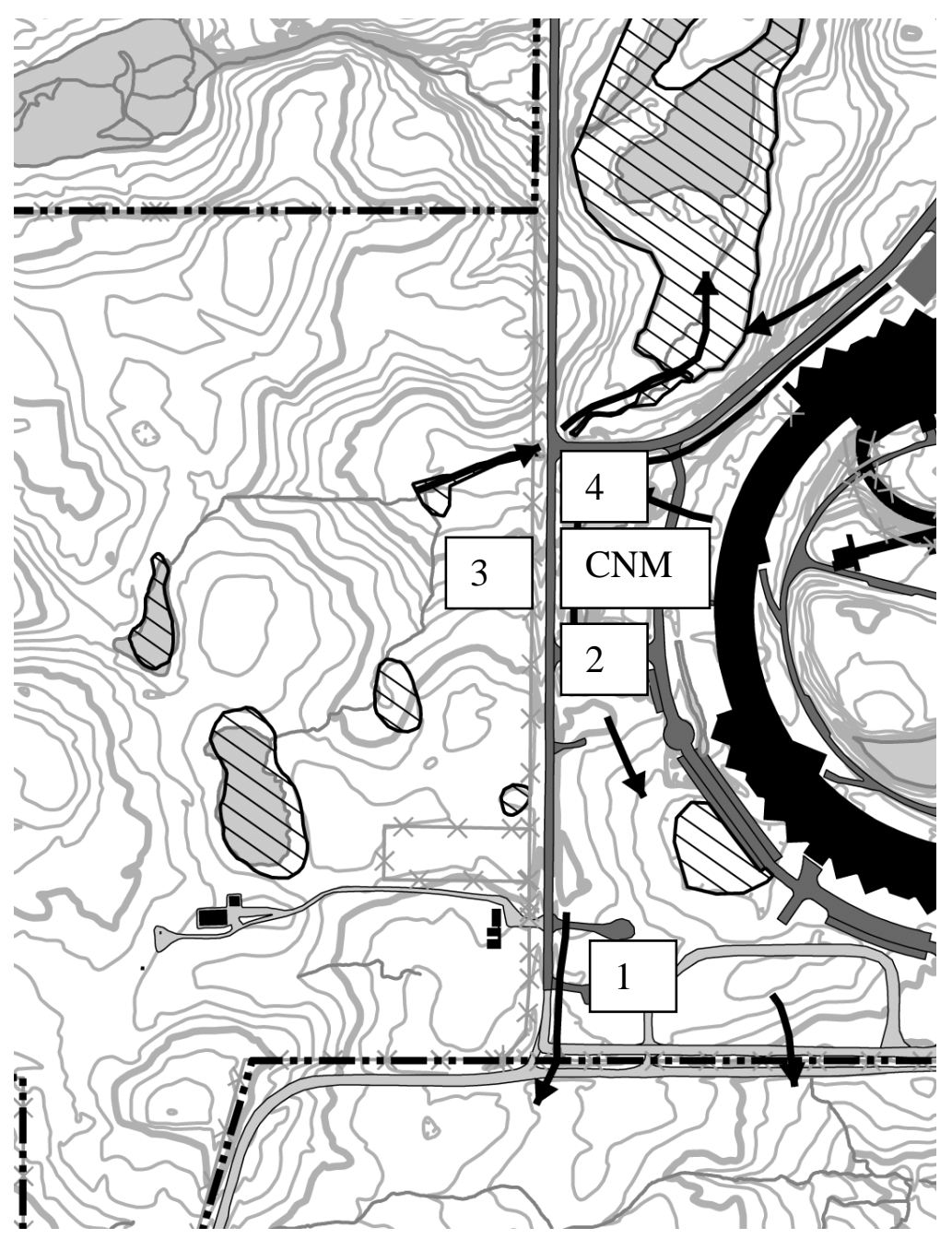

FIGURE E.1 Alternative Parking Lot Sites

Site 3 would be located west of the CNM across Kearney Road. This area is designated in ANL-E plans as being a potential site for future development. Drainage from the location could either flow north into Wetland 302 following existing drainage patterns, or the drainage could be collected and pumped south to drain across the southern Argonne boundary. This location is in an area of wet soils that may not support parking lot construction without additional filling. In addition, it is an area adjacent to designated wetlands and cultural resources. Issues related to site drainage are essentially comparable to similar issues with Site 4. This site is not evaluated in detail the EA because of concerns about wetlands, cultural resources, and soil characteristics, as well as conflict with future development.

For Sites 1, 2, and 3, an additional 16,000 $\mathrm{ft}^{2}\left(150 \mathrm{~m}^{2}\right)$ of handicapped and VIP parking would be still be provided at the CNM entrance. 
TABLE E.1 Parking Lot Alternatives

\begin{tabular}{|c|c|c|c|}
\hline Site & Location & Drainage & Other Considerations \\
\hline 1 & $\begin{array}{l}\text { Southwest corner } \\
\text { of APS site } \\
\text { (Kearney and Bluff } \\
\text { Roads) }\end{array}$ & $\begin{array}{l}\text { - Storm water runoff drains } \\
\text { to south. } \\
\text { - Tiered parking lot could } \\
\text { be constructed. }\end{array}$ & $\begin{array}{l}\text { - Location of potential future development } \\
\text { can be avoided. } \\
\text { - Parking lot location is up to } 1 / 4 \text { to } 1 / 2 \text { mile } \\
\text { from CNM and LOM } 437 \\
\text { - This option would require construction } \\
\text { of up to } 3,000 \mathrm{ft}^{2} \text { of additional } \\
\text { walkways. }\end{array}$ \\
\hline 2 & $\begin{array}{l}\text { West of LOM } 436 \\
\text { (along Kearney } \\
\text { Road, south of the } \\
\text { CNM site) }\end{array}$ & $\begin{array}{l}\text { - Storm water runoff drains } \\
\text { to south }\end{array}$ & $\begin{array}{l}\text { - Location of potential future } \\
\text { development. } \\
\text { - Site is near the CNM, but at the back of } \\
\text { the building. }\end{array}$ \\
\hline 3 & $\begin{array}{l}\text { West of Kearny } \\
\text { Road and CNM } \\
\text { building }\end{array}$ & $\begin{array}{l}\text { - Stormwater runoff drains } \\
\text { to the north. } \\
\text { - Stormwater runoff could } \\
\text { be pumped to the south. }\end{array}$ & $\begin{array}{l}\text { - Soil condition unfavorable for parking } \\
\text { lot construction. } \\
\text { - Site is near the CNM, but across Kearney } \\
\text { Road. }\end{array}$ \\
\hline 4 & $\begin{array}{l}\text { Southeast corner of } \\
\text { Kearny and Bluff } \\
\text { Roads }\end{array}$ & $\begin{array}{l}\text { - Stormwater runoff drains } \\
\text { to the north. } \\
\text { - Stormwater runoff could } \\
\text { be pumped to the south. }\end{array}$ & $\begin{array}{l}\text { Proposed location for the CNM parking } \\
\text { lot. } \\
\text { Most convenient site for the CNM. }\end{array}$ \\
\hline
\end{tabular}

Site 4 is the proposed location of parking for the CNM. To address the concern of quality of stormwater runoff flowing into Wetland 302 from this site, several engineering approaches were evaluated. At this site, drainage could either be directed into Wetland 302 without control, collected and pumped to drain south, or allowed to drain into Wetland 302 through a series of bioswales. The topography of the site precludes gravity-driven stormwater drainage to the south of the CNM (Figure E.2). The lowest drainage point south of the APS site is $736 \mathrm{ft}(224 \mathrm{~m}$ ) above sea level requiring $1,750 \mathrm{ft}(533 \mathrm{~m})$ of drainage pipe to be laid from the proposed parking lot site. For a gravity drainage system to be effective, the CNM parking lot would have to be elevated to $757 \mathrm{ft}(231 \mathrm{~m})$. This is $13 \mathrm{ft}(4 \mathrm{~m})$ higher than the CNM building floor and the existing APS experiment floor. It would also be $20 \mathrm{ft}(6.1 \mathrm{~m})$ above the elevation of Kearney and Rock Roads (737 ft [225 m] above sea level).

Because it is of high importance to maintain and enhance the functionality of Wetland 302 for mitigation purposes, the option of draining a parking lot into Wetland 302 without further control was not analyzed in detail.

If stormwater from the parking lot at Site 4 was collected, it could be pumped and discharged at the southern boundary of the ANL-E site. This would divert water from 


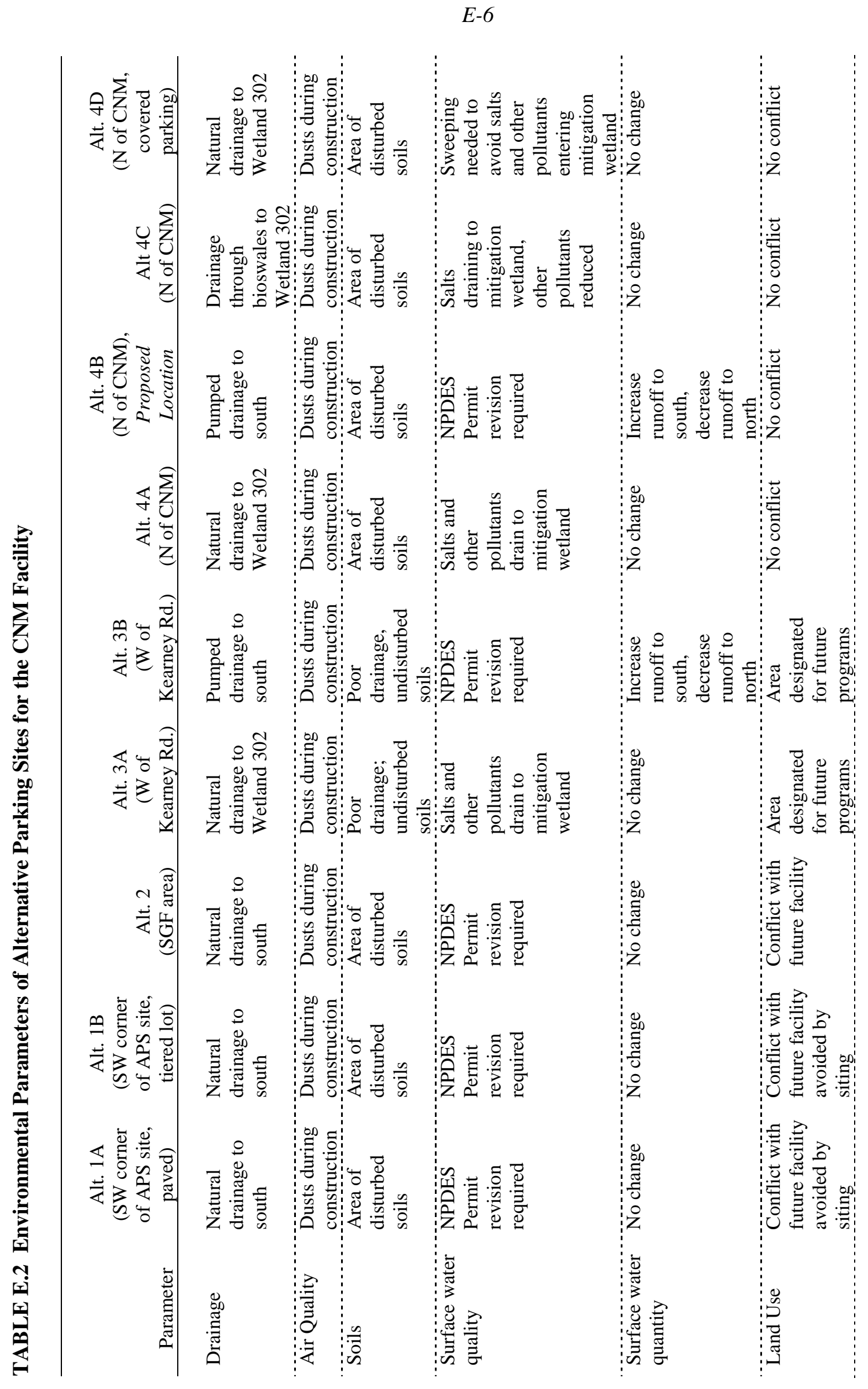




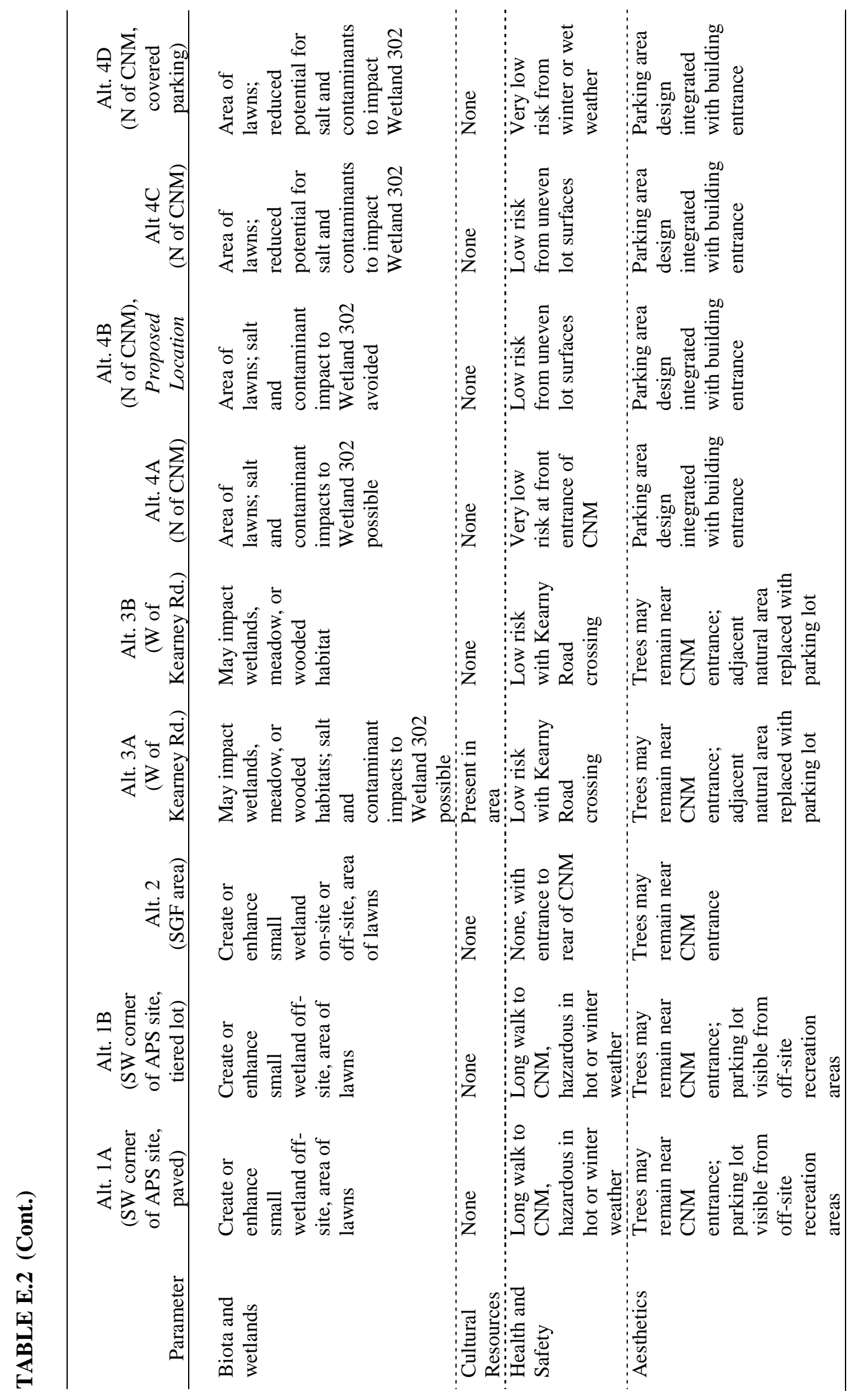


Wetland 302, but also would carry salts and other pollutants away. A significant amount of paved area adjacent to the CNM must remain at the floor level $(744 \mathrm{ft}[227 \mathrm{~m}])$. Roadways and delivery, loading, and pedestrian walkway locations would still remain since there is no practical way to drain these areas to the south.

A covered parking area was briefly considered for Site 4, but this alternative was not analyzed in further detail because of cost and the necessity of administrative controls to remove parking lot pollutants by mechanical means. To increase cost effectiveness, covered or tiered parking was also considered for Site 2, where there is space for additional parking for other future facilities.

In summary, considering the characteristics of potential parking lot site location, this EA analyzes in further detail four alternatives: Site 1-Option A, Site 1-Option B, Site 4-Option B, and Site 4-Option C (see Table E.2 for descriptions).

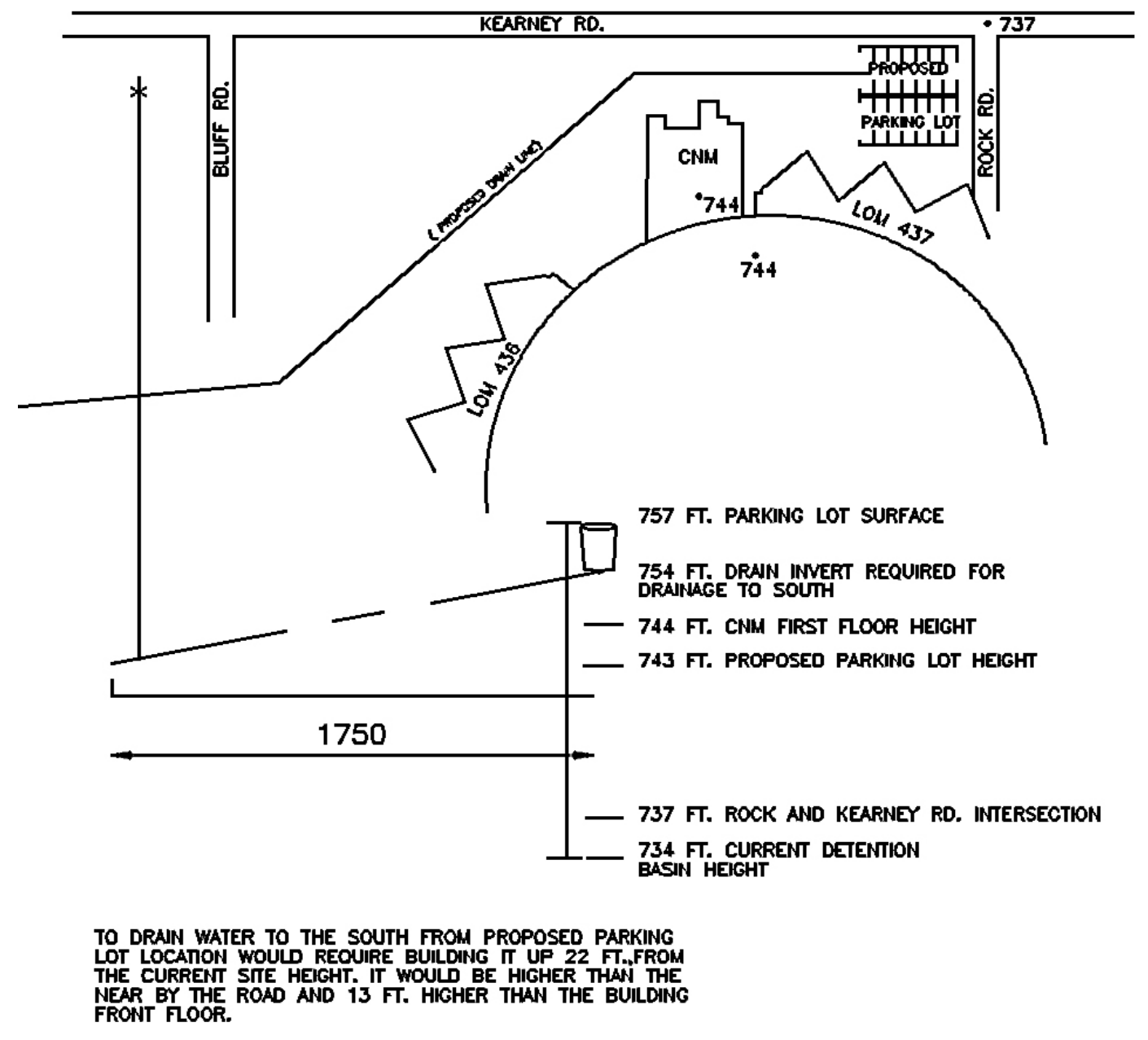

FIGURE E.2 Surface Elevations Associated with Stormwater Drainage Alternatives 